\author{
University of São Paulo \\ "Luiz de Queiroz" College of Agriculture
}

Diet's protein supplementation and Haemonchus contortus infection relation to the homeostasis, ovarian gene expression and histology of peripubertal ewes

\title{
Paula Suarez Henriques
}

Thesis presented to obtain the degree of Doctor in

Science. Area: Animal Science and Pastures

Piracicaba

2021 
Paula Suarez Henriques

Veterinary Surgeon

Diet's protein supplementation and Haemonchus contortus infection relation to the homeostasis, ovarian gene expression and histology of peripubertal ewes

Advisor:

Prof. Dr. HELDER LOUVANDINI

Thesis presented to obtain the degree of Doctor in Science. Area: Animal Science and Pastures 
Dados Internacionais de Catalogação na Publicação DIVISÃO DE BIBLIOTECA - DIBD/ESALQ/USP

Henriques, Paula Suarez

Diet's protein supplementation and Haemonchus contortus infection relation to the homeostasis, ovarian gene expression and histology of peripubertal ewes / Paula Suarez Henriques. - - Piracicaba, 2021.

$99 \mathrm{p.}$

Tese (Doutorado) - - USP / Escola Superior de Agricultura "Luiz de Queiroz".

1. Ovelhas púberes 2. Proteína dietética 3. Ovário 4. Expressão gênica 5. Infecção 6. Haemonchus contortus I. Título 


\section{DEDICATÓRIA}

Dedico esta tese aos meus pais Neli Suárez Henriques e Alberto Henriques(in memorian), que possibilitaram minha formação como pessoa e profissional, me ensinaram a ser o melhor ser humano possível, a ser ética sem jamais tirar vantagem ou prejudicar outras pessoas. 


\section{AGRADECIMENTOS}

Agradeço às agências de fomento CNPq (processo número: 141846/2017-8) e CAPES pela bolsa de doutorado que me permitiu fazer minha pesquisa. Agradeço também tanto ao CNPq(processo número 420373/20160) e FAPESP (2017/50451-0) pelo financiamento dos custos do projeto.

Agradeço às minhas tias Maria Lúcia Suárez Linhares e Maria de Lourdes González Suárez que me apoiaram enormemente durante minha vida e pós-graduação.

Agradeço a meu noivo Ricardo Cardoso Leite e minha filha Helena Egido Suárez por suportarem minhas longas ausências durante o doutorado.

Agradeço ao meu orientador, prof. Helder Louvandini por possibilitar que eu desenvolvesse meu projeto de pesquisa em seu grupo.

Agradeço aos funcionários do CENA Caciara Barbosa Taba, Andrea Calvento Kaproski e George Guilherme Berner que foram solícitos e competentes em seu trabalho, desta forma me ajudando em vários momentos desafiadores do doutorado.

Agradeço a profa. Tsai Siu Mui por ter permitido o uso de seu laboratório onde realizei muitos dos meus experimentos. 


\section{CONTENTS}

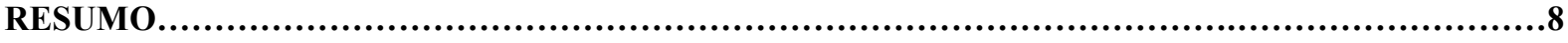

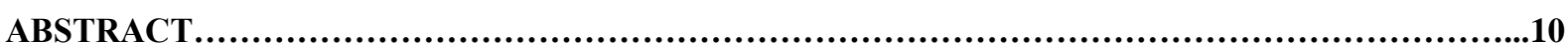

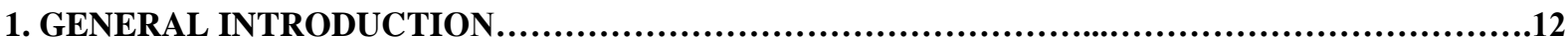

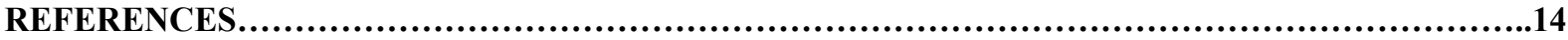

2. DIFFERENT LEVELS OF DIETETIC PROTEIN, INFECTION WITH HAEMONCHUS CONTORTUS AND SERUM AMH INFLUENCE OVARIAN PRIMORDIAL FOLLICLE AND

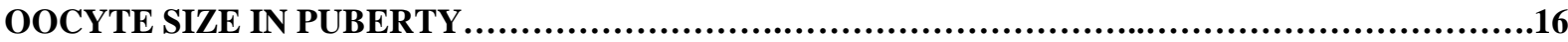

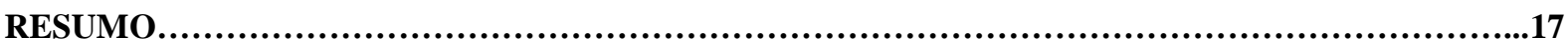

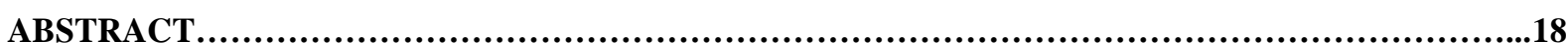

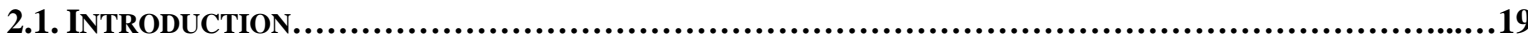

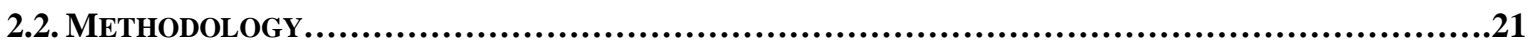

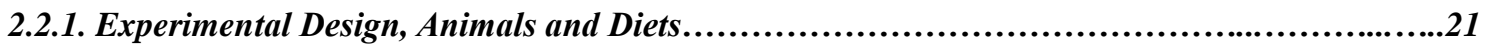

2.2.2. Bromatological Analysis of the Diet..................................................................................................23

2.2.3. Absence of Oestrus Synchronisation in the Ewe Lambs.............................................................20

2.2.4. Blood collection, Complete Blood Count and Blood Biochemical Analysis......................................23

2.2.5. White Blood Cell Counts........................................................................................................................24

2.2.6. Faecal Egg Count.....................................................................................................................24

2.2.7. Beta-Hydroxybutyrate Concentration..............................................................................................24

2.2.8. Anti-Mullerian Hormone Concentration........................................................................................24

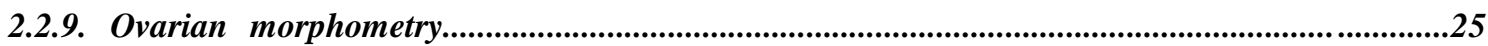

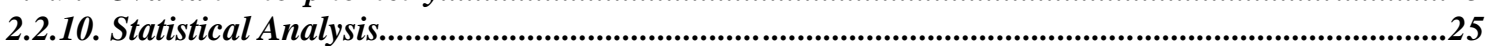

2.2.10.1. The Explanatory Model of Physiological Influence on Oocyte's and Primordial Follicle's

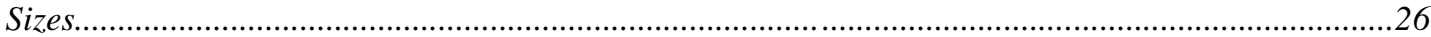

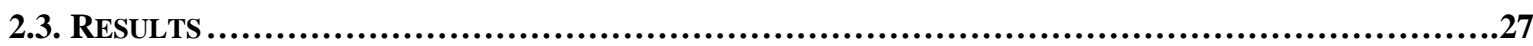

2.3.1. Biochemical and Haematological Parameters....................................................27

2.3.2. Number of Haemonchus contortus Eggs in the Faeces...........................................27

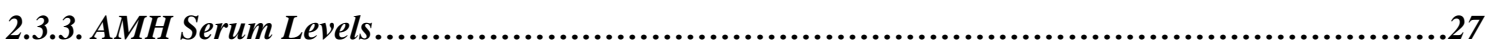

2.3.4. Size of Ovarian Primordial Follicles and Oocytes.................................................28

2.3.5. Model of Physiological Influence on Oocyte' and Primordial Follicle' Sizes........................28

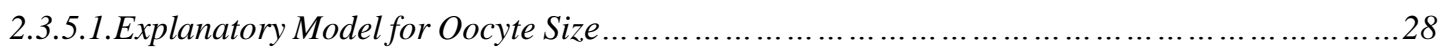

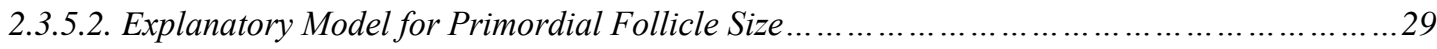

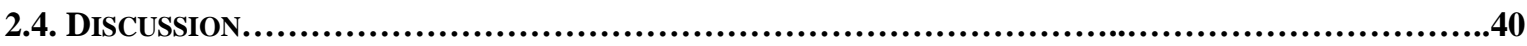

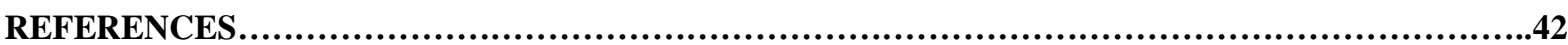

3. SUPPLEMENTATION OF PROTEIN IN THE DIET OF PERIPUBERTAL INFECTED EWE LAMBS ENABLES THE EXPRESSION OF OVARIAN GENES RELATED TO FOLLICLE

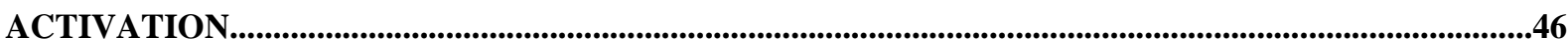

RESUMO

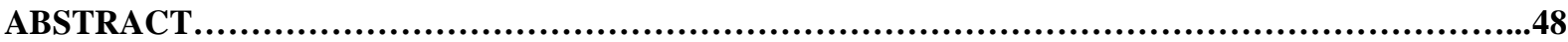

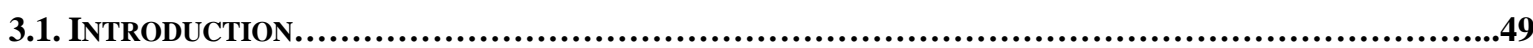

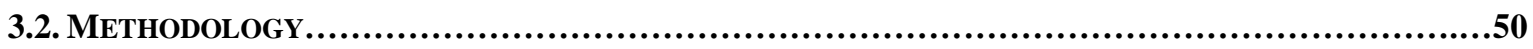


3.2.1.Experimental Design, Animals and Diets.........................................................50

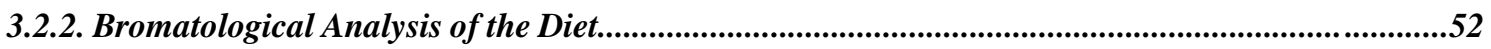

3.2.3. Absence of Oestrus Synchronisation in the Ewe Lambs.............................................................53

3.2.4. Blood collection, Complete Blood Count and Blood Biochemical Analysis....................................53

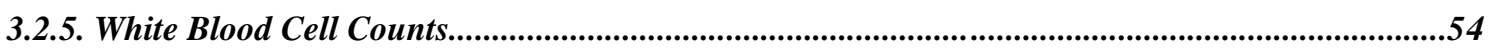

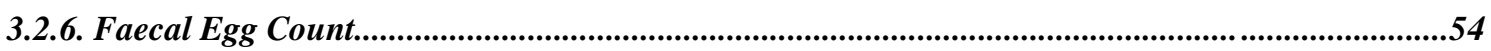

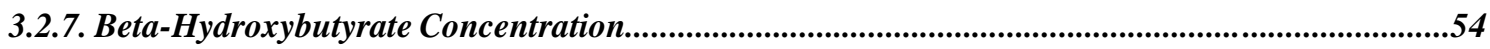

3.2.8. Statistical Analyses of Faecal Egg Counts, Beta-Hydroxybutyrate Levels, Blood Cell and

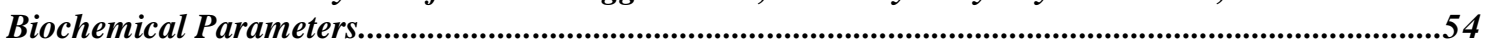

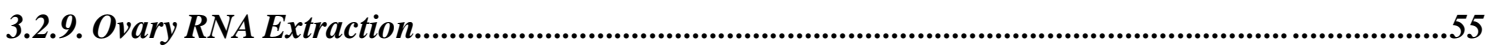

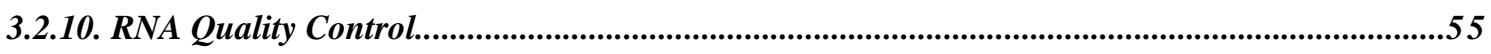

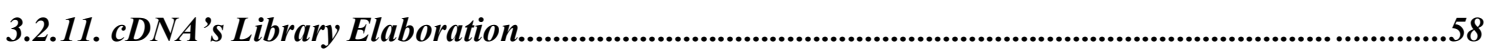

3.2.12. Library Sequencing................................................................................................................58

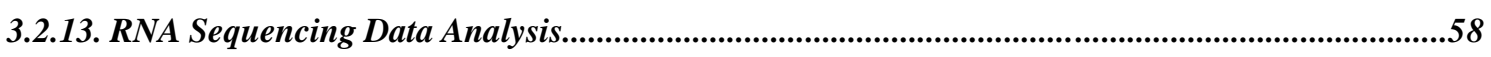

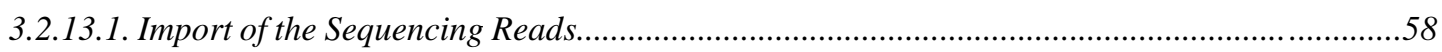

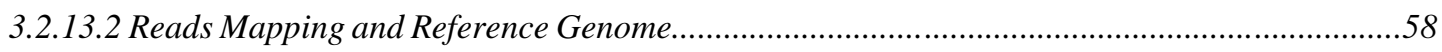

3.2.13.3. Normalisation of RNA Sequencing Data.........................................................................5

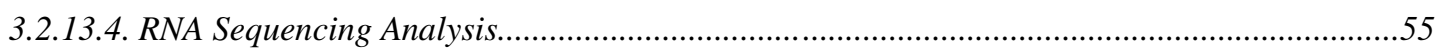

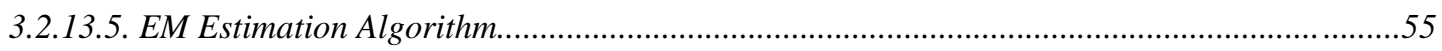

3.2.13.6. Differential Expression Analysis of the RNA Sequencing Data...............................................60

3.2.14. Analysis of Differentially Expressed Gene Lists to Identify Enriched Pathways Shared or Selectively Enriched Between Groups...................................................................................................61

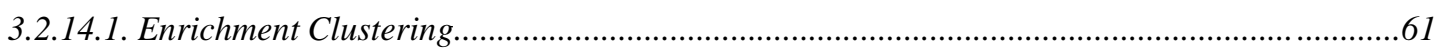

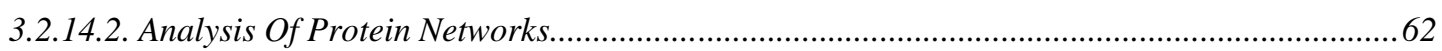

3.2.14.3. Statistical Methodology Used in the Enrichment Analysis.....................................................63

3.2.15. RT-qPCR to Validate Gene Expression.........................................................................................64

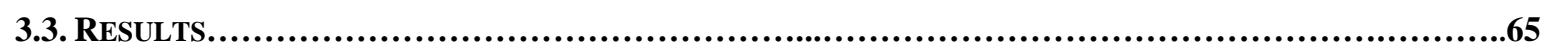

3.3.1. Biochemical and Haematological Parameters...................................................65

3.3.2. Number of Haemonchus contortus eggs in the Faeces............................................66

3.3.3. Results of RNA Sequencing's Raw Data Filtering...............................................66

3.3.4. Sequencing Data Summary .......................................................................66

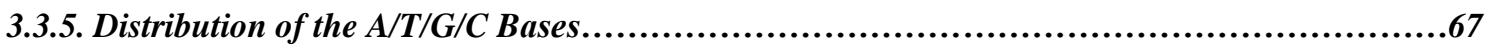

3.3.6 RNAseq Differential Expression Analysis.............................................................................

3.3.6.1. Differentially Expressed Genes in the Comparisons Supplemented Not Infected Vs Control Not Infected Groups and Supplemented Infected Vs Control Infected

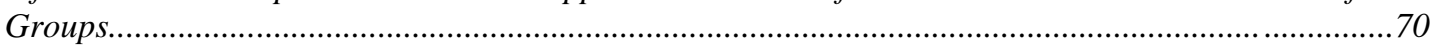

3.3.6.2. Enriched Pathways and Biological Processes in the Differentially Expressed

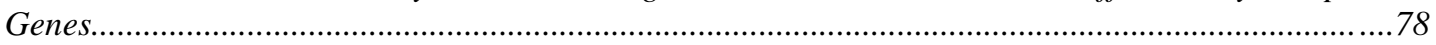

3.3.6.2.1. Comparison Between the Supplemented Not Infected Vs Control Not Infected

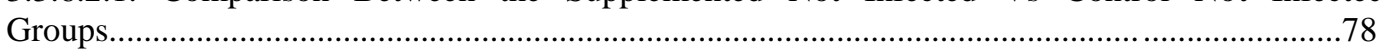

3.3.6.2.2. Comparison Between the Control Not Infected Vs Supplemented Not Infected

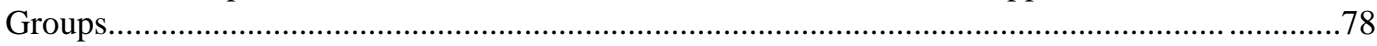


3.3.6.2.3. Comparison Between the Supplemented Infected Vs Control Infected Groups. .84

3.3.6.2.4. Comparison Between Control Infected and Supplemented Infected Groups...................84

3.3.6.2.5. Protein Network Analysis... .89

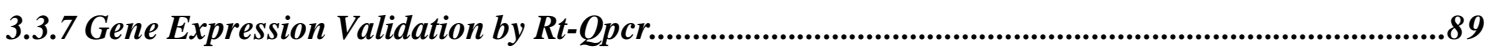

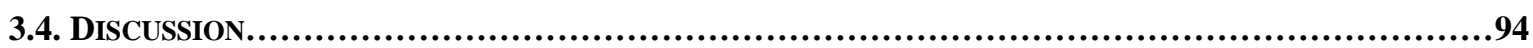

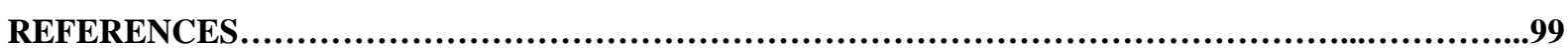




\section{RESUMO}

\section{A relação da suplementação de proteína na dieta e infecção por Haemonchus contortus com a homeostase, morfometria e expressão gênica ovarianas em ovelhas peri-púberes}

O manejo da nutrição em ovelhas pode ser uma ferramenta eficiente para melhorar a performance ovariana. Os nutrientes absorvidos são transportados pela circulação sanguínea para os tecidos do organismo. O estado nutricional e fisiológico da borrega pode interferir com o desenvolvimento ovariano e fertilidade.Uma deficiência em proteína no sangue, causada pela infecção abomasal com o parasita Haemonchus contortus, é prejudicial ao desenvolvimento dos organismos durante a puberdade, causando indesejável atraso na manifestação da puberdade. A infecção exige maior consumo de proteína para reparar o dano causado pelo parasita nos tecidos, repor as perdas sanguíneas e para elaborar a resposta imune. A resposta imune ao H.contortus melhora com a suplementação de proteína na dieta.H.contortus se torna resistente aos anti-helmínticos em pouco tempo de exposição a um princípio ativo. Além disso, existe a possibilidade que os anti-helmínticos deixem resíduos em produtos e dejetos ovinos, afetando a saúde humana e o meio ambiente. Portanto a primeira parte de nosso estudo teve como objetivo avaliar se parâmetros morfométricos do ovário e parâmetros fisiológicos poderiam ser melhorados em animais peri-púberes infectados suplementados com proteína na dieta. Para isso nós usamos 18 borregas da raça Santa Inês (Ovis aries) entre 6 e 7 meses de idade, filhas do mesmo reprodutor. Elas foram alimentadas com 12\%(grupos controle) ou 19\% de proteína(grupos suplementados) na dieta. Após 35 dias consumindo esta dieta, elas foram infectadas artificialmente via oral com 10.000 larvas estágio L3 de Haemonchus contortus (grupos infectados) ou não(grupos não infectados). Em quatro momentos do período experimental, nós avaliamos os níveis séricos de hormônio anti-mulleriano(AMH) com um teste ELISA, parâmetros celulares e bioquímicos do sangue e número de ovos de H. contortus nas fezes. Após 42 dias de infecção e 77 dias de dieta, os ovários esquerdos das borregas foram retirados cirurgicamente e nós examinamos sua morfometria por análise histológica.As borregas suplementadas com proteína infectadas $(n=5)$, proteína controle infectadas $(n=5)$, suplementadas com proteína não infectadas $(n=4)$ e proteína controle não infectadas $(n=4)$ não tiveram peso corporal final diferente. $\mathrm{Na}$ análise de proteína plasmática em relação a dieta e infecção em ANOVA fatorial, o nível de proteína na dieta foi significativo $(\mathrm{p}=0.02)$. O tamanho de folículo primordial variou significativamente com a interação proteína na dieta*infecção $(\mathrm{p}<0.05)$ e o tamanho de oócito variou significativamente com o nível de proteína na dieta $(\mathrm{p}=0.047)$. Nós criamos um Modelo explanatório Linear Misto para avaliar se diferentes dietas, status de infecção, e parâmetros fisiológicos observados durante o experimento influenciaram no tamanho de oócito e folículo primordial. Porque os nutrientes circulantes chegando ao ovário podem mudar sua expressão gênica, nós avaliamos também a expressão gênica ovariana destas borregas. Sendo que a ativação do crescimento folicular é uma característica essencial do potencial reprodutivo feminino, nós objetivamos determinar se suplementando proteína na dieta de animais infectados, a expressão de genes ovarianos seria beneficiada levando a ativação folicular em momento mais precoce que suas irmãs não suplementadas. Para chegar a este objetivo, nós extraímos e sequenciamos RNA dos seus ovários esquerdos.A suplementação de proteína em animais infectados levou a uma maior expressão de genes(FDR p-value < 0.05) e processos biológicos $(\mathrm{p}<0.01)$ ligados a ativação meiótica em folículos pré-ovulatórios e ativação de folículos primordiais entre outros processos biológicos.Os animais suplementados não infectados també tiveram maior expressão de genes e processos ligados a meiose e outros como comportamento circadiano. Os animais não suplementados tiveram expressão menor destes processos e maior expressão de processos relacionados a morfogênese tecidual, inflamação e resposta imune. Com o primeiro estudo nós concluímos que a dieta, infecção, AMH sérico, parâmetros sanguíneos celulares e bioquímicos influenciaram o tamanho de oócito e folículo primordial. No estudo de expressão gênica nossa conclusão foi que a suplementação de proteína para animais peri-púberes infectados permitiu a expressão de genes ovarianos relacionados a estágios de maturação folicular mais adiantado que suas irmãs infectadas e não suplementadas com proteína. E a suplementação de proteína em borregas não infectadas também levou a uma expressão maior de genes e processos relacionados a ativação meiótica. Em contraste, suas irmãs com nível de proteína controle apresentaram menor expressão destes genes e processos.

Palavras-chave: Ovelha púbere, Ovário, Expressão gênica, Proteína dietética, Infecção, Haemonchus contortus, AMH 


\title{
ABSTRACT \\ Diet's protein supplementation and Haemonchus contortus infection relation to the homeostasis, ovarian gene expression and histology of peripubertal ewes
}

\begin{abstract}
In ewes, the management of nutrition can be an efficient management tool to improve ovarian performance. Nutrients after being absorbed are transported by circulating blood to all tissues in the body. The ewe lamb nutritional and physiological state may interfere with the ovarian environment and fertility. A deficiency of protein in the blood caused by an Haemonchus contortus abomasal infection is detrimental to the organism's development during puberty, causing an undesirable delay in puberty manifestation. Pubertal delay leads to economic losses in sheep breeding economic systems. The infection demands a higher protein intake to repair the damage caused by the parasite in sheep's tissues, replenish the blood losses, and build the host's immune response. The immune response to H.contortus improves with supplementation of protein in the sheep's diet. H.Contortus become resistant to anthelminthic therapy shortly after they are exposed to a new treatment.Moreover, there is the possibility of contamination by anthelmintic drugs in ovine products, possibly affecting human health and the environment. This study's objective was to evaluate if ovarian and clinical parameters can be incremented in peripubertal infected animals through more sustainable management than anthelmintic usage. We used a 2 x 2 factorial model where eighteen Santa Inês ewe lambs (Ovis aries) between 6 - 7 months old - born to the same ram were fed with one of the two dietetic's protein levels (12\% or 19\%). After 35 days of being fed this diet, they were infected or not with 10,000 Haemonchus contortus L3 larvae. We assessed AMH plasma levels with an ELISA test and blood's cells and biochemical parameters during the experimental period at four different times. Following 42 days of infection and 77 days of the diet, the lambs had their left ovaries removed, and we examined ovarian morphometrics through histological analysis. The groups Supplemented Protein Infected( $\mathrm{n}=5)$, Control Protein Infected( $\mathrm{n}=5)$, Supplemented Protein Not Infected $(n=4)$ and Control Protein Not Infected $(n=4)$ did not differ in their bodyweight gain.In the analysis of plasma protein related to diet and infection in factorial ANOVA, the diet's protein level was significant $(p=0.02)$. Primordial follicle size varied significantly with the interaction diet*infection $(\mathrm{p}<0.05)$ and oocyte size varied significantly with the level of protein in the diet $(p=0.047)$. We created an explanatory linear mixed model to evaluate how diet, infection, and physiological parameters influenced the primordial follicle and oocyte size. Because the circulating nutrients reaching the ovary can change its gene expression, we decided to assess its gene expression. Ovarian follicle growth activation is an essential feature controlling female reproductive potential. We aimed to determine if supplementing protein in infected animals' diet would impact the ovarian environment leading to timely ovarian follicle activation. After 77 days on this diet and 42 days of infection, we extracted RNA from their left ovaries and sequenced it to accomplish this goal. We found that protein supplementation in infected animals led to an up-regulation of genes and biological processes linked to meiotic activation in pre-ovulatory follicles and primordial follicle activation, among other processes. The supplemented not infected animals also up-regulated genes and processes linked to meiosis and other processes such as circadian behaviour. The animals that were not supplemented had these same processes down-regulated while they up-regulated processes related to tissue morphogenesis, inflammation and immune response. We concluded that serum AMH, blood cells and biochemical parameters, diet and infection influenced oocyte size and primordial follicle size in peripubertal ewes.

Furthermore, diet's protein supplementation of peripubertal infected animals allowed them to express genes related to a more mature ovarian follicle stage than their half-sisters infected and not supplemented with protein. The supplementation of protein in not infected ewe lambs also led to up-regulation of genes and meiotic activation processes. In contrast, their half-sisters with control level of protein did not up-regulate these genes.
\end{abstract}

Keywords: Peripubertal Ewe; Ovary; Gene expression; Dietetic Protein; Infection; Haemonchus contortus 


\section{GENERAL INTRODUCTION}

Peripubertal ewes are the source of a sheep's flock renewal. This animal category is more susceptible to environmental challenges such as helminth infection, because they require a higher amount of nutrients to grow and develop. Helminth infection causes anaemia, ulcerative lesions in the abomasal mucosa, a decline in feed intake, impaired efficient nutrient utilisation, exacerbated host's mucus production and antibody production (Amarante, 2014). These symptoms may cause impaired development, delay in the puberty manifestation and, if the rate of helminth larvae infestation is high, could ultimately cause death (Houdijk et al., 2001).

If there is not enough circulating protein during parasites infestation, the organism tends to catabolise protein from skin, gut and ultimately muscle to generate glucose and inflammatory response proteins. Although being a necessary short-term adaptation, it is finite because there are low protein reserves available in lambs. So, it is more difficult for a lamb to resist negative protein balance because of its decreased body mass reserves (Houdijk, 2012; Houdijk et al., 2001).

Supplementation of protein in the diet improved the sheep's immune response to helminth infection (Coop et al., 1995). Supplying adequate proteins and energy intake improve protein balance by increasing protein synthesis, although it does not stop protein degradation during the illness. Resistance to the nematodes infection in sheep is related to the immune response built by the host. Protein seems to have a higher impact on the immune response (Calder, 1995) to parasites (Bricarello et al., 2005; Louvandini et al., 2006) than energy. However protein depends on energy effects to avail amino acids for protein deposition and mobilisation, so protein supply cannot be considered in isolation(Adams and Liu, 2003).

This relationship between energy and protein is reciprocal. The energetic balance relies on the diet protein as it enables the lipoprotein synthesis, lipoprotein transports cholesterol, required for steroid hormone synthesis(Stocco, 2001). If there is a protein deficit in the ovarian growth/development stage its development can be affected. Another consequence for a nutritional deficit in ewe lambs is presenting delayed first ovulation(Tena-Sempere, 2012). Late puberty leads to a smaller number of lambs during the ewe's life an undesirable characteristic in sheep's breeding systems.

Using nutrition to manipulate reproductive outcomes is an inexpensive management tool to control ovulation rate and litter size particularly in low cost, extensive production systems (Martin et al., 2004; Torres-Acosta et al., 2012). Nutrition interferes with follicle's recruitment and growth by metabolic signals to the ovary. Metabolic signals differ with the animal's metabolic status (Hunter et al., 2004; Lucy, 2003). It is known that high energy diets can bring positive changes to reproductive parameters in ewes(Abecia et al., 1997). When ruminants are in positive energy balance, they present enhanced folliculogenesis, maximum natural ovulation rate and advanced puberty (Scaramuzzi et al., 2006).

The ovulation rate in sheep increased when they received an intravenous infusion of branched-chain amino acids (Downing et al., 1995) . A higher concentration of plasma amino acids was associated with oocyte quality in dairy heifers (Rooke et al., 2009). An intermediate level of protein supplementation in adult ewes improved reproductive response (Rodrigues et al., 2015).The offspring of female mice with restricted diet's protein during preconception through to weaning presented a reduction of primordial follicles of $37 \%$ at 21 days post birth and $51 \%$ at 24 weeks(Winship et al., 2018).

There are a few studies relating to nutritional changes that modified ovarian gene expression. In Hu-sheep ewes with different nutrition levels, a differential expression of 170 ovarian granulosa cells' genes was detected, among these genes were up-regulated PTGS2, UCP2, steroidogenic acute regulatory protein, interleukin-1A and interleukin-1B(Luo et al., 2016). Texel breed ewes consuming a flushing diet differentially expressed 118 ovarian genes in comparison to the ones not eating this diet. One of these genes, CST6 - which inhibits ovulation - was down-regulated. Since CST6 inhibits 
ovulation, this change in expression could help promoting ovulation. In the same study though, Finnsheep breed ewes gene expression was less responsive to the same diet (Pokharel et al., 2018).

The nematode infections are generally treated with anthelminthic drugs, but helminths become resistant to new active ingredients in a short period after being exposed to them (Avramenko et al., 2020; Besier and Love, 2003; Jackson et al., 2012; Jackson and Coop, 2000). So, there is a necessity for constant modification of active ingredients, and new active ingredients take a long time to be developed(Pathak, 2017). Besides, anthelminthic therapy increases the sheep production costs and may leave residuals in sheep's milk, meat and waste (Sargison, 2011; Tsiboukis D, Sazakli E, Jelastopulu E, 2013). As residuals' presence in food products is becoming a significant complaint in public health and environment, more sustainable management to fight helminthic infections should be sought.

It is known that an extra supply of protein improved resistance and clinical parameters in sheep infected with nematodes. Would the protein supplementation also influence a change in ovary's gene expression, leading to advantage in ovarian parameters in infected peripubertal ewes compared to those not protein supplemented? The aim of our study was answering these questions. 


\section{REFERENCES}

Abecia, J.A., Lozano, J.M., Forcada, F., Zarazaga, L., 1997. Effect of level of dietary energy and protein on embryo survival and progesterone production on day eight of pregnancy in Rasa Aragonesa ewes. Anim. Reprod. Sci. 48, 209-218. https://doi.org/10.1016/S0378-4320(97)00021-3

Adams, N.R., Liu, S.M., 2003. Principles of nutrient partitioning for wool, growth and reproduction: Implications for nematode parasitism. Aust. J. Exp. Agric. https://doi.org/10.1071/EA03007

Amarante, A.F.T. do, 2014. Os parasitas de ovinos, Os parasitas de ovinos. https://doi.org/10.7476/9788568334423

Avramenko, R.W., Redman, E.M., Windeyer, C., Gilleard, J.S., 2020. Assessing anthelmintic resistance risk in the postgenomic era: A proof-of-concept study assessing the potential for widespread benzimidazole-resistant gastrointestinal nematodes in North American cattle and bison. Parasitology 147, 897-906. https://doi.org/10.1017/S0031182020000426

Besier, R.B., Love, S.C.J., 2003. Anthelmintic resistance in sheep nematodes in Australia: The need for new approaches. Aust. J. Exp. Agric. https://doi.org/10.1071/EA02229

Bricarello, P.A., Amarante, A.F.T., Rocha, R.A., Cabral Filho, S.L., Huntley, J.F., Houdijk, J.G.M., Abdalla, A.L., Gennari, S.M., 2005. Influence of dietary protein supply on resistance to experimental infections with Haemonchus contortus in Ile de France and Santa Ines lambs. Vet. Parasitol. 134, 99-109. https://doi.org/10.1016/j.vetpar.2005.05.068

Calder, P.C., 1995. Fuel utilization by cells of the immune system. Proc. Nutr. Soc. 54, 65-82. https://doi.org/10.1079/PNS19950038

Coop, R.., Huntley, J.., Smith, W.., 1995. Effect of dietary protein supplementation on the development of immunity to Ostertagia circumcincta in growing lambs. Res. Vet. Sci. 59, 24-29. https://doi.org/10.1016/00345288(95)90025-X

Downing, J.A., Joss, J., Scaramuzzi, R.J., 1995. A mixture of the branched chain amino acids leucine, isoleucine and valine increases ovulation rate in ewes when infused during the late luteal phase of the oestrous cycle: an effect that may be mediated by insulin. J. Endocrinol. 145, 315-23.

Houdijk, J.G.M., 2012. Differential effects of protein and energy scarcity on resistance to nematode parasites. Small Rumin. Res. 103, 41-49. https://doi.org/10.1016/j.smallrumres.2011.10.017

Houdijk, J.G.M., Jessop, N.S., Kyriazakis, I., 2001. Nutrient partitioning between reproductive and immune functions in animals. Proc. Nutr. Soc. 60, 515-525. https://doi.org/10.1079/PNS2001114

Hunter, M.., Robinson, R.., Mann, G.., Webb, R., 2004. Endocrine and paracrine control of follicular development and ovulation rate in farm species. Anim. Reprod. Sci. 82-83, 461-477. https://doi.org/10.1016/J.ANIREPROSCI.2004.05.013

Jackson, F., Coop, R.L., 2000. The development of anthelmintic resistance in sheep nematodes. Parasitology 120. https://doi.org/10.1017/s0031182099005740

Jackson, F., Varady, M., Bartley, D.J., 2012. Managing anthelmintic resistance in goats-Can we learn lessons from sheep? Small Rumin. Res. 103, 3-9. https://doi.org/10.1016/j.smallrumres.2011.10.012 Louvandini, H., Veloso, C.F.M., Paludo, G.R., Dell'Porto, A., Gennari, S.M., McManus, C.M., 2006. Influence of protein supplementation on the resistance and resilience on young hair sheep naturally infected with 
gastrointestinal nematodes during rainy and dry seasons. Vet. Parasitol. 137, 103-111. https://doi.org/10.1016/j.vetpar.2006.01.004

Lucy, M.C., 2003. Mechanisms linking nutrition and reproduction in postpartum cows. Reprod. Suppl. https://doi.org/10.1530/biosciprocs.5.031

Martin, G.B., Milton, J.T.B., Davidson, R.H., Banchero Hunzicker, G.E., Lindsay, D.R., Blache, D., 2004. Natural methods for increasing reproductive efficiency in small ruminants. Anim. Reprod. Sci. 82-83, 231-245. https://doi.org/10.1016/j.anireprosci.2004.05.014

Pathak, A.K., 2017. Dairy and Vet Sci J Nutritional Bases to Control Gastrointestinal Parasites of Livestock. Dairy Vet Sci J 4. https://doi.org/10.19080/JDVS.2017.04.555632

Pokharel, K., Peippo, J., Honkatukia, M., Seppälä, A., Rautiainen, J., Ghanem, N., Hamama, T.M., Crowe, M.A., Andersson, M., Li, M.H., Kantanen, J., 2018. Integrated ovarian mRNA and miRNA transcriptome profiling characterizes the genetic basis of prolificacy traits in sheep (Ovis aries). BMC Genomics 19. https://doi.org/10.1186/s12864-017-4400-4

Rodrigues, M., Silva, L.M., da Silva, C.M.G., Ara??jo, A.A., Nunes-Pinheiro, D.C.S., Rondina, D., 2015. Reproductive and metabolic responses in ewes to dietary protein supplement during mating period in dry season of Northeast Brazil. Cienc. Anim. Bras. 16, 24-36. https://doi.org/10.1590/1089-6891v16i124613

Rooke, J.A., Ainslie, A., Watt, R.G., Alink, F.M., McEvoy, T.G., Sinclair, K.D., Garnsworthy, P.C., Webb, R., 2009. Dietary carbohydrates and amino acids influence oocyte quality in dairy heifers. Reprod. Fertil. Dev. 21, 419427. https://doi.org/10.1071/RD08193

Sargison, N.D., 2011. Pharmaceutical Control of Endoparasitic Helminth Infections in Sheep. Vet. Clin. North Am. Food Anim. Pract. 27, 139-156. https://doi.org/10.1016/j.cvfa.2010.10.014

Scaramuzzi, R.J., Campbell, B.K., Downing, J.A., Kendall, N.R., Khalid, M., Muñoz-Gutiérrez, M., Somchit, A., 2006. A review of the effects of supplementary nutrition in the ewe on the concentrations of reproductive and metabolic hormones and the mechanisms that regulate folliculogenesis and ovulation rate. Reprod. Nutr. Dev. 46, 339-354. https://doi.org/10.1051/rnd:2006016

Stocco, D.M., 2001. StAR Protein and the Regulation of Steroid Hormone Biosynthesis. Annu. Rev. Physiol. 63, 193213. https://doi.org/10.1146/annurev.physiol.63.1.193

Tena-Sempere, M., 2012. Deciphering puberty: Novel partners, novel mechanisms. Eur. J. Endocrinol. 167, $733-747$. https://doi.org/10.1530/EJE-12-0669

Torres-Acosta, J.F.J., Sandoval-Castro, C.A., Hoste, H., Aguilar-Caballero, A.J., Cámara-Sarmiento, R., Alonso-Díaz, M.A., 2012. Nutritional manipulation of sheep and goats for the control of gastrointestinal nematodes under hot humid and subhumid tropical conditions. Small Rumin. Res. 103, 28-40. https://doi.org/10.1016/j.smallrumres.2011.10.016

Tsiboukis D, Sazakli E, Jelastopulu E, L.M., 2013. Anthelmintics residues in raw milk. Assessing intake by a children population. Pol J Vet Sci. 85-91. https://doi.org/10.2478/pjvs-2013-0012.

Winship, A.L., Gazzard, S.E., Cullen-McEwen, L.A., Bertram, J.F., Hutt, K.J., 2018. Maternal low-protein diet programmes low ovarian reserve in offspring. Reproduction 156, 299-311. https://doi.org/10.1530/REP-180247 


\title{
2. DIFFERENT LEVELS OF DIETETIC PROTEIN, INFECTION WITH HAEMONCHUS CONTORTUS AND SERUM AMH INFLUENCE OVARIAN PRIMORDIAL FOLLICLE AND OOCYTE SIZE IN PUBERTY
}

RESUMO

\author{
Níveis diferentes de proteína dietética, infecção com Haemonchus contortus e AMH sérico \\ influenciam tamanho de folículo primordial ovariano e oócito na puberdade
}

\begin{abstract}
Em ovelhas a manipulação da nutrição pode ser uma ferramenta de manejo eficiente para melhorar a performance ovariana. A primeira onda de ativação de folículos primordiais é parte da iniciação da puberdade e fertilidade. A infecção por helmintos no abomaso pode causar um atraso indesejável na manifestação da puberdade. Este tipo de infecção exige do organismo uma quantidade maior de proteína, necessária para reparar o dano causado pelo parasita no abomaso da ovelha, para repor as perdas sanguíneas e construir a resposta imune da ovelha. Os parasitas se tornam resistentes a anti-helmínticos pouco tempo após sua exposição a um novo medicamento. Além disso, existe a possibilidade de resíduos que estes medicamentos deixam em produtos ovinos como leite, carne e dejetos, provavelmente afetando a saúde humana e o meio ambiente. O objetivo de nosso estudo foi avaliar se parâmetros ovarianos e clínicos poderiam ser incrementados em animais peripúberes infectados, por um manejo mais sustentável que o uso de anti-helmínticos. Nós usamos um modelo fatorial $2 \times 2$ onde dezoito borregas Santa Inês(Ovis aries) entre 6 e 7 meses de idade - nascidas do mesmo reprodutor - foram alimentadas ou com uma dieta proteína controle $(12 \%)$ ou com suplementação de proteína(19\%). Após 35 dias se alimentando desta dieta, as borregas foram artificialmente infectadas ou não com 10.000 larvas L3 do helminto Haemonchus contortus. Durante o período experimental nós avaliamos em quatro momentos diferentes o nível de AMH sérico e parâmetros bioquímicos e celulares do sangue. Depois de 42 dias de infecção e 77 dias de dieta, as borregas tiveram seus ovários esquerdos retirados e examinamos a morfometria ovariana por análise histológica. Os grupos Suplementadas Infectadas $(\mathrm{n}=5)$, Proteína Controle Infectadas(n=5), Suplementadas Não Infectadas(n=4) e Proteína Controle Não Infectadas(n=4) não diferiram quanto ao ganho de peso corpóreo.Na ANOVA de proteína plasmática em relação à dieta e infecção, o nível de proteína na dieta foi significativo $(\mathrm{p}=0.02)$. $\mathrm{O}$ tamanho de folículo primordial variou significativamente com a interação da dieta e infecção $(\mathrm{p}<0.05)$ e o tamanho de oócito variou significativamente com a $\operatorname{dieta}(\mathrm{p}=0.047)$. Nós criamos um modelo explanatório linear misto para avaliar como a dieta, infecção e parâmentros fisiológicos influenciaram o tamanho de folículo primordial e tamanho de oócito. Nós concluímos que o AMH sérico, parâmentros bioquímicos e celulares sanguíneos, dieta e infecção influenciaram o tamanho de oócito e folículo primordial em ovelhas peripúberes.
\end{abstract}




\title{
ABSTRACT
}

\section{Different levels of dietetic protein, infection with Haemonchus contortus and serum AMH influence ovarian primordial follicle and oocyte size in puberty.}

\begin{abstract}
In ewes, the manipulation of nutrition can be an efficient management tool to improve ovarian performance. The first activation wave of primordial follicles is part of the onset of puberty and fertility. Abomasal helminth infection may cause an undesirable delay in puberty manifestation. The infection demands a higher amount of protein, required to repair the damage caused by the parasite in sheep's tissues, replenish the blood losses, and build the host's immune response. Helminths become resistant to drug therapy shortly after they are exposed to a new treatment. Moreover, there is the possibility of contamination by anthelmintic drugs in ovine products, possibly affecting human health and the environment. This study's objective was to evaluate if ovarian and clinical parameters can be incremented in peripubertal infected animals through more sustainable management than anthelmintic usage. We used a 2 x 2 factorial model where eighteen Santa Inês ewe lambs (Ovis aries) between $6-7$ months old - born to the same ram - were fed with one of the two dietetic's protein levels $(12 \%$ or 19\%). After 35 days of being fed this diet, they were infected or not with 10,000 Haemonchus contortus L3 larvae. We assessed at four different time points AMH plasma levels with an ELISA test and blood's cells and biochemical parameters during the experimental period. Following 42 days of infection and 77 days of the diet, the lambs had their left ovaries removed, and we examined ovarian morphometrics through histological analysis. The groups Supplemented Protein Infected(n=5), Control Protein Infected( $n=5)$, Supplemented Protein Not Infected $(n=4)$ and Control Protein Not Infected $(n=4)$ did not differ in their bodyweight gain. In the analysis of plasma protein related to diet and infection in factorial ANOVA, the diet's protein level was significant $(\mathrm{p}=0.02)$. Primordial follicle size varied significantly with the interaction diet*infection $(\mathrm{p}<0.05)$ and oocyte size varied significantly with the level of protein in the diet $(\mathrm{p}=0.047)$. We created an explanatory linear mixed model to evaluate how diet, infection, and physiological parameters influenced the primordial follicle and oocyte size. We concluded that serum AMH, blood cells and biochemical parameters, diet and infection influenced oocyte size and primordial follicle size in peripubertal ewes.
\end{abstract}

Keywords: Puberty; Ewe lambs; Ovary; Dietetic Protein; Infection; Haemonchus contortus 


\subsection{INTRODUCTION}

The pathological consequences to highly infected animals by Haemonchus contortus are anaemic syndrome, disturbances of digestive and absorptive processes, reduced appetite and interference in the blood coagulation (Balic et al., 2000). The anaemia provides the blood with fewer nutrients and haemoglobin to the whole organism. The vessels feeding the ovaries will also be supplied with the anaemic blood, affecting the ovary's health. A regular vascularisation in the theca ovarian layer was already shown to indicate the ovarian follicles' health (Jiang et al., 2003; Mattioli et al., 2001). The nutritional deficit in an ewe lamb could lead to a late first ovulation - late puberty arousal. In this context, when the ovulation does happen, the corpus luteum devoid of sufficient blood nutrients could be incapable of secreting enough progesterone to maintain a gestation (Tena-Sempere, 2012). Nutrients that manage to be absorbed will likely be redirected from tissues to maintain blood and tissue homeostasis. In the order of priorities for the ewe lamb, the primary necessity is to attain homeostasis, as it is essential for their survival, and the second one is to generate their offspring (H. Hoste, J.F.J. TorresAcosta J. Quijada, I. Chan-Perez, M.M. Dakheel, D.S. Kommuru, I. Mueller-Harvey, 2017).

Ovarian primordial follicles are the source of developing follicles and oocytes for the ewe's whole reproductive lifespan, and they remain dormant until their activation. They are formed by an oocyte arrested at meiosis I and adjoining somatic cells called granulosa cells. The initial events in ovarian primordial follicle activation are growth of the oocyte and a change in the granulosa cells from a flattened to a cuboidal morphology, increasing primordial diameter follicle and oocyte (Hirshfield, 1991). The recruitment of primordial follicles differs from other folliculogenesis phases. It can begin without extra ovarian hormonal input, thus not depending on the pituitary hormones (Follicle-stimulating hormone and Luteinising hormone) to be activated (Campbell et al., 2004; Silva et al., 2004). The first activation wave of primordial follicles is part of the onset of puberty and fertility in young adulthood and depends on the mice's granulosa cells(Liu et al., 2014; Zhang, Hua; Liu, 2015).

AMH plays an essential role in ovarian primordial follicle recruitment and dominant follicle selection in mice, rats and humans (Weenen et al., 2004). AMH inhibits the activation of primordial follicles (Durlinger et al., 2002) and by doing this, preserves the ovarian reserve to be depleted precociously. It is used as an endocrine marker for the women's ovarian reserve (Visser et al., 2006) . Also, plasma AMH concentration in prepubertal ewe lambs could be a reliable marker of the ovarian status as it correlated with fertility at their first mating at ten months age (Lahoz et al., 2012).

H. contortus populations around the world develop resistance to commercial anthelmintic therapy in a short amount of time after being first used (Jackson et al., 2012; Van den Brom et al., 2015). Dietetic protein supplementation can improve the resilience of the sheep to the infection (Louvandini et al., 2006) reducing dependence on anthelminthic drugs and avoiding the residues of these drugs in the sheep's milk and meat that humans consume. Sheep fed with more protein can express an adequate immune response to helminthic infection without being deprived of their reproductive ability (Houdijk, 2012; Houdijk et al., 2001). Studies observed that supplementing protein in the diet to not infected animals can raise progesterone levels (Abecia et al., 1997; Berardinelli et al., 1998; Rodrigues et al., 2015) and induced a corpus luteum with higher quality (Rodrigues et al., 2015).

There is a lack of knowledge on the impact of nutrition and gastrointestinal disease by $\mathrm{H}$. contortus in peripubertal ewe lambs' ovarian status. Most of the studies considering reproductive parameters in infected animals were done with periparturient sheep, infected with Teladorsagia (Houdijk et al. 2005) or Trichostrongylus (Kahn, 2003).They were mainly assessing aspects of the immune response during this period. During pregnancy, it was demonstrated that higher fat and protein reserves, especially before lambing, improved ewe's resilience to Haemonchus contortus (Macarthur et al., 
2013). The peripubertal period is a stage of intense body growth and reproductive maturation when the animals require more nutrients to develop. Our objective was to measure the effect of supplementing dietetic protein to infected ewe lambs' in their homeostasis and reproductive parameters, avoiding the usage of anthelmintics therapy. We evaluated the ovarian histology, levels of serum AMH, blood cell counts, haemoglobin and blood biochemical parameters of these ewe lambs to accomplish this goal. 


\subsection{METHODOLOGY}

This research project was approved by the Bioethics Commission of São Paulo University (CENA-USP, protocol number 004/2017), which complies with animal research ethical principles.

\subsubsection{Experimental design, animals and diets}

We used a 2 x 2 factorial with 18 Santa Ines ewe lambs, between six and seven months old and bred by the same ram. They were raised and kept in a helminth-free environment monitored by quarterly examination of individual faecal samples. The four groups were balanced according to the animals' weight and age. The average age and weight for each group are detailed in Table 1. The housing environment was illuminated by natural light during the whole experiment.

The lambs were fed individually, twice a day with two different protein levels of an isocaloric diet during a 92 days experiment. Diets were composed of soybean meal, ground corn, Tifton-85(Cynodon spp) chopped hay and mineral salt $(2,23 \%)$ in proportions defined in Table 2, bromatological composition of the diet ingredients are detailed in Table 3. The formulation of the diet followed the general guidelines of the NRC (2007). The amount of diet provided was calculated for the animals' body weight and adjusted every 14 days according to their current body weight.

Individual feed intake was also controlled because the animals were housed in individual pens, and the leftover feed was weighed daily. Animals had free access to the water. After 35 days of consuming this diet, the ewe lambs were either orally infected (Infected groups) or not (Not Infected groups) with 10,000 stage 3 larvae of the nematode Haemonchus contortus. Following 77 days of consuming this diet and 42 days of being infected, they had their left ovaries collected to examine their morphometry through histological analysis.

Table 1. Average liveweight and age (+/- standard deviation) for each group at the beginning and end of the experiment

\begin{tabular}{|c|c|c|c|c|}
\hline & $\begin{array}{l}\text { Control protein } \\
\text { Not Infected }\end{array}$ & $\begin{array}{l}\text { Control protein } \\
\text { Infected }\end{array}$ & $\begin{array}{l}\text { Supplemented protein } \\
\text { Not infected }\end{array}$ & $\begin{array}{l}\text { Supplemented protein } \\
\text { Infected }\end{array}$ \\
\hline $\begin{array}{l}\text { Mean weigth of the } \\
\text { group at the } \\
\text { beginning of the } \\
\text { experiment }(\mathrm{kg})\end{array}$ & $\begin{array}{l}22.2 \\
(+/-5.5)\end{array}$ & $\begin{array}{c}23.5 \\
(+/-3.9)\end{array}$ & $\begin{array}{c}21.5 \\
(+/-7.2)\end{array}$ & $\begin{array}{c}22.1 \\
(+/-5.6)\end{array}$ \\
\hline $\begin{array}{l}\text { Mean weigth of the } \\
\text { group at the end of } \\
\text { the experiment }(\mathrm{kg})\end{array}$ & $\begin{array}{l}29.5 \\
(+/-4.2)\end{array}$ & $\begin{array}{c}31.7 \\
(+/-4.4)\end{array}$ & $\begin{array}{c}28.1 \\
(+/-11.4)\end{array}$ & $\begin{array}{c}29.1 \\
(+/-6.4)\end{array}$ \\
\hline $\begin{array}{l}\text { Mean group's age at } \\
\text { the start of } \\
\text { experiment(days) }\end{array}$ & $\begin{array}{l}220 \\
(+/-5.4)\end{array}$ & $\begin{array}{c}217 \\
(+/-9.6)\end{array}$ & $\begin{array}{c}215 \\
(+/-5.9)\end{array}$ & $\begin{array}{c}208 \\
(+/-7.7)\end{array}$ \\
\hline $\begin{array}{l}\text { Mean age of the } \\
\text { group(days) at the } \\
\text { end of } \\
\text { experiment }\end{array}$ & $\begin{array}{l}299 \\
(+/-5.4)\end{array}$ & $\begin{array}{c}296 \\
(+/-9.6)\end{array}$ & $\begin{array}{c}294 \\
(+/-5.9)\end{array}$ & $\begin{array}{c}287 \\
(+/-7.7)\end{array}$ \\
\hline
\end{tabular}


Table 2. Composition of the control and supplemented protein diets

\section{Control protein diet Supplemented protein diet}

\section{Forage feed}

Tifton-85 hay

\section{Concentrated feed}

Ground corn

Soybean meal

\section{Crude protein}

( $\%$ total diet)
$60 \%$

$60 \%$

$32 \%$

$16 \%$

$8 \%$

$24 \%$

\subsubsection{Bromatological analysis of the diet}

Dry matter in the diet was calculated after being dried out in an electric kiln (Odontobrás 1.6, Brazil) at $105^{\circ} \mathrm{C}$ for 24 hours. Calculations of mineral matter were done after burning the diet sample out in a muffle furnace (JUNG, Brazil) at $550^{\circ} \mathrm{C}$ for five hours and 30 minutes. The amount of crude protein was established with a microKjeldahl method of vapour distillation (Tecnal, Brazil) using $15 \mathrm{~mL}$ of sodium hydroxide with volatilised nitrogen $(\mathrm{NaOH} 12 \mathrm{~N})$ being collected in the boric acid solution at 2\%(H3BO3) and quantified by titration with a sulfuric acid solution (H2SO4 $0.005 \mathrm{~N}$ ) with multiplication by conversion factor 6.25. The ethereal extract's quantification was done with petroleum ether by heating it in a fat extractor (Soxhlet- TE-044-8/50 - Tecnal, Brazil). The fibre in neutral detergent was quantified after washing the diet samples in fibre quantification bags Ankom F57(Ankom Technology Corp., USA), at $90^{\circ} \mathrm{C}$ for 1 hour with a neutral detergent solution (Van Soest et al., 1991) with the addition of alphaamylase and sodium sulfite (TE-149 - Tecnal, Brazil) followed by two washes with distilled water plus alpha-amylase at $90^{\circ} \mathrm{C}$ for five minutes and another wash with acetone for five minutes. These bags were put in the electric kiln at $105^{\circ} \mathrm{C}$ (Odontobrás, Brazil) during four hours and then in a dryer, were weighed in an analytical balance (UY220, Japão) and transferred to porcelain crucibles to be incinerated in a muffle furnace (JUNG, Brasil) at $530^{\circ} \mathrm{C}$ for 3 hours and 30 minutes. Then the fibre in neutral detergent was calculated after correction of ashes. The fibre in acid detergent (FDA) was estimated after washing the diet samples in bags with an acid detergent solution at $90^{\circ} \mathrm{C}$ for 60 minutes followed by four rinses in distilled water at $90^{\circ} \mathrm{C}$ during five minutes and another wash with acetone for five minutes. Diet samples bags were put in an electric kiln at $105^{\circ} \mathrm{C}$ for four hours, then in a dryer until reaching $25^{\circ} \mathrm{C}$ to be weighed. The lignin was estimated using the FDA bags. After the weighing, the bags were put in a sulfuric acid solution at $72 \%$ during three hours. They were rinsed with distilled water at $90^{\circ} \mathrm{C}$ for five minutes and washed with acetone for another five minutes. Diet samples bags were put in an electric kiln at $105^{\circ} \mathrm{C}$ for four hours, then were weighed and put in porcelain crucibles to burn out in a muffle furnace at $530^{\circ} \mathrm{C}$ for three hours and 30 minutes. The lignin and 
FDA were calculated after the correction for ashes. The diet's ingredients energy was quantified in the calorimeter bomb 6200(Parr Instrument Company - USA) after the combustion.

Table 3. Bromatological composition $\left(\mathrm{g} \mathrm{kg}^{-1}\right.$ of dry matter at $\left.100^{\circ} \mathrm{C}\right)$ and energy $(\mathrm{MJ})$ of the diets' ingredients

\begin{tabular}{llll}
\hline & $\begin{array}{l}\text { Concentrated } \\
\text { feed } \\
\text { Supplemented } \\
\text { Protein }\end{array}$ & $\begin{array}{l}\text { Concentrated } \\
\text { feed Control }\end{array}$ & $\begin{array}{l}\text { Tifton-85 } \\
\text { protein }\end{array}$ \\
& 897.11 & & \\
\hline Dry matter at $\mathbf{1 0 5}^{\circ} \mathbf{C}$ & 317.69 & 153.04 & 877.90 \\
Crude Protein & 0.018 & 0.018 & 104.20 \\
Energy & 246.26 & 168.34 & 0.019 \\
Fiber in neutral detergent & 188.75 & 131.89 & 3827.90 \\
Fiber in acid detergent & 14.88 & 23.19 & 20.70 \\
Ethereal extract & 99.60 & 84.63 & 66.87 \\
Mineral matter & 26.93 & 25.75 & \\
Lignin & 10.21 & 8.39 & \\
Phosphorus & & & \\
\hline
\end{tabular}

\subsubsection{Absence of oestrus synchronisation in the ewe lambs}

Hormonal therapy to synchronise the oestrus would contradict our line of research because our objectives were to study how supplementing protein in the animals' diet could help maintain the homeostasis, indirectly benefitting reproductive parameters in the peripubertal period - thus avoiding the usage of anthelmintics therapy. After all, the carryover of chemicals into food products, such as sheep milk and meat, is increasing concerns of public health. Also, because one of the reproductive indicators we evaluated is serum AMH concentration and, synchronisation programs might reverse the possible association between AMH and patterns of follicle growth (Batista et al., 2020; Ribeiro et al., 2014). Moreover, Morotti et al., (2017) found that AMH concentrations, according to progesterone above or below one $\mathrm{ng} / \mathrm{mL}$ were not different. This relationship may vary depending on the breed of cattle studied. Also, in Japanese Black cattle after three superovulation hormonal treatments, AMH concentration decreased significantly (Hirayama et al., 2017). The data cited show that hormonal therapy to synchronise the oestrus would probably influence the results, and these would only be reproducible if this technique were used again.

\subsubsection{Blood collection, complete blood count and blood biochemical analysis}

Five $\mathrm{mL}$ of blood was collected from the animals' jugular vein before being fed in the morning. The blood was collected in vacutainer tubes with or without EDTA. Immediately after collected, the blood samples in EDTA were analysed in the automatic analyser Davol Poch-100iV Diff. The level of beta-hydroxybutyrate was also measured in four different dates during the experiment.

Blood was sampled from the animals on four different dates. The parameters analysed were hematocrit, number of red blood cells (RBC), number of white blood cells (WBC), haemoglobin (HGB), mean corpuscular 
hemoglobin $(\mathrm{MCH})$, number of platelets, mean corpuscular volume (MCV) and mean corpuscular hemoglobin concentration (MCHC).

Samples without EDTA were centrifuged for 15 minutes at $1310 \mathrm{~g}$ at $4^{\circ} \mathrm{C}$ to obtain blood serum which was aliquoted and stored at $-20^{\circ} \mathrm{C}$ until the biochemical analysis was performed. The plasma albumin levels, glucose, urea and plasma protein were measured with Labtest kits (Labtest Diagnóstica S.A.- Brazil) following the manufacturer instructions and its reading performed by spectrophotometer (Perkin Eusing Elmer - Lambda EZ150 UV/Vis Spectrophotometer).

\subsubsection{White blood cell counts}

The white blood cells were counted in blood smears of each animal on the four dates by counting the first 100 cells visualized in the microscope at a 100x magnification of a Nikon Eclipse E200 microscope (Sohani, 2018).

\subsubsection{Faecal egg count}

The level of infection was monitored every two weeks by faecal egg count of each individual. Faeces were sampled directly from the ewe lambs' rectum, and the eggs present were counted in a McMaster chamber under the Nikon Eclipse E200 microscope according to the methodology by Coles et al., (1992).

\subsubsection{Beta-hydroxybutyrate concentration}

We assessed beta-hydroxybutyrate's concentration because its high levels in the blood can have detrimental effects on the ovarian follicles. Its concentration was measured in four different dates throughout the experiment. On the first date, the lambs had been on a high or low protein diets for one month but had not been infected yet. The three subsequent measurements were done after the artificial oral infection with the 10,000 Haemonchus contortus L3 stage larvae. Its concentration was assessed with Freestyle Optium Beta-Ketone test (Abbot) in fresh blood just after its collection.

\subsubsection{Anti-Mullerian hormone concentration}

The anti-Mullerian hormone (AMH) concentration was measured in serum samples collected in four different dates throughout the experiment. Upon blood collection, the samples were allowed to clot for 20 minutes at room temperature. They were centrifuged for 20 minutes at $3000 \mathrm{rpm}$, their supernatant was micro pipetted and stored at $-20^{\circ} \mathrm{C}$ until the ELISA assay was performed. The ELISA assays were performed on the same day

All ELISA kit reagents were warmed to room temperature for 30 minutes; the serum samples were unfrozen and stabilised to room temperature.

The serum AMH concentration was assessed with a sandwich kit Enzyme-Linked Immunoabsorbent Assay (Sheep Anti-Mullerian Hormone ELISA kit - Bioassay Technology Laboratory - China - Cat. No E0088Sh). The sensitivity of the test is of $0.02 \mathrm{ng} / \mathrm{mL}$, intra-assay precision of $\mathrm{CV}<8 \%$, and inter-assay precision of $\mathrm{CV}<10 \%$. The AMH standard was reconstituted to generate dilutions of $16,8,4,2,1,0.5,0.25,0.125,0.0625$ and $0.03125 \mathrm{ng} / \mathrm{mL}$. The $40 \mu \mathrm{L}$ serum samples were used undiluted. Both serum samples and standards had their concentration measured in duplicate. In brief, we used a 96 well plate which comes already pre-coated with sheep AMH antibody. We added $50 \mu \mathrm{L}$ of each standard, to standard wells and $40 \mu \mathrm{L}$ sample to sample wells and added $10 \mu \mathrm{L}$ of anti-AMH antibody to sample wells. Then $50 \mu \mathrm{L}$ of streptavidin-horseradish-peroxidase were added to standard and sample wells. The samples were incubated at $37^{\circ} \mathrm{C}$ for 60 minutes, washed five times with the kit's washing buffer and incubated 10 
minutes at $37^{\circ} \mathrm{C}$ with substrate solutions $\mathrm{A} \& \mathrm{~B}$. After the stop solution was added, the optical density of each well was determined through absorbance with the filter set to $450 \mathrm{~nm}$.

Once we obtained the standard wells' optical density (OD) values, a standard curve was constructed by plotting the average OD for each standard on the $\mathrm{Y}$-axis against the concentration on the $\mathrm{X}$-axis. The best fit curve for these values was calculated with the CurveExpert Professional software version 2.7, which generated a polynomial regression equation(degree $=2$ ) to calculate the samples' concentrations. For this curve/equation, the correlation coefficient(r) was 0.997 , the coefficient of determination was 0.995 and the standard error 0.043 .

The concentration of AMH was not used to classify the ewe lambs in categories because they were going through the peripubertal period, on different diets and infection statuses, so we could not predict the concentrations of $\mathrm{AMH}$ resemble under all those conditions.

\subsubsection{Ovarian morphometry}

The left ovaries from 18 ewe lambs between 10 and 11 months old were collected for histological analysis making a total of four ovaries in the Control Protein not infected group, five ovaries in the Control Protein infected group, four ovaries in the supplemented Protein not infected group and, five ovaries in the High Protein infected group.

Ovaries were cut in fragments and fixed in Carnoy's solution for 4 hours and conserved in 70\% ethanol until they were further histologically processed. Ovarian fragments were dehydrated in $80 \%$ ethanol, $90 \%$ ethanol and $100 \%$ ethanol. After being dehydrated, they were put in xylene baths and embedded in moulds with paraffin at $58^{\circ} \mathrm{C}$. After these molds with the fragments solidified, they were sectioned in a microtome into $5 \mu \mathrm{m}$ thickness sections. The sections were put into slides and stained according to the Periodic acid - Schiff protocol. The stained sections were observed in 40X microscopic magnification Axioskop2-Zeiss-Germany). Images of the sections were acquired with the AxioCam MRC-Zeiss camera. The analysis of these images was done using AxioVision LE64 software. We counted the firstly observed 30 follicles following only one direction in the slide to avoid counting the same follicles twice and, classified them in primordial, transitional, primary, secondary and antral follicle categories. Among these categorised follicles, we separated the ovarian follicles in morphologically normal or atretic. The criteria to consider an ovarian follicle morphologically healthy was the presence of an intact basal membrane, well-organised granulosa cell layers and, an intact oocyte. For morphometric analysis, 15 healthy primordial follicles and their corresponding oocytes had their sizes measured. We measured the larger and smaller axes from the basement membrane to calculate the size of the primordial follicles; the same procedure was performed in the larger and smaller axes of the oocytes to calculate their sizes, so we had 30 measurements of primordial follicles and 30 measurements of oocyte per ewe lamb, this methodology was adapted from Bezerra et al., (2018).

\subsubsection{Statistical Analyses}

For all the analysis done, we used standardized parameters' values (Individual value - Mean of the group/standard deviation). Shapiro-Wilks analysis was performed on all the measurements of the data to ensure its normality.

Pearson correlation analysis was previously performed in all the variable plasma pairs (plasma protein, albumin, haemoglobin, glucose, beta-hydroxybutyrate in total blood), serum AMH and number of red blood cells to 
ensure a non-linearity relationship between them. To evaluate variation according to the interaction of protein level in the diet (Diet: Supplemented versus Control) and the status of infection (Infection: Infected versus Not Infected we used Factorial ANOVA. Furthermore, to evaluate variation according to the passing of time during the experiment, we used ANOVA repeated measures. The covariance analysis followed a model where the level of the protein on the diet (Supplemented or Control) and Infection status (Infected or Not Infected) were categorical factors; the plasma variables were the dependent variables and $\mathrm{AMH}$ the continuous predictor. We also performed covariation analysis to examine a possible influence of AMH on several physiological factors and primordial follicle and oocyte sizes. The analysis above were performed in the software STATISTICA (StatSoft - version 12).

\subsubsection{The explanatory model of physiological influence on oocyte' and primordial follicle' sizes}

We built an explanatory linear mixed model considering fixed and random effects to understand how the fourth date's physiological parameters related to the ovarian histological parameters. We named this as "model of physiological influence on oocyte and primordial follicle size". Each model's dependent variables were the size of oocyte and size of the primordial follicle, as their increase in size means they are being activated/recruited to the next maturation stage. The fixed effects considered in the initial model were the interaction of Diet and Infection status, level of plasma protein, albumin, urea, haemoglobin, AMH, glucose, beta-hydroxybutyrate, number of red blood cells (RBC), number of neutrophils, lymphocytes and monocytes. The random-effects initially considered were age and individual (ewe lamb).

Although the initial full model included the data mentioned above, their inclusion as explaining (independent) variables in the linear mixed model increased Akaike Inference Criterion's value. Akaike Inference Criterion (AIC) is a number used to classify a model in more explanatory or less explanatory, the lower AIC is, the more explanatory the model is. The inclusion of all variables did not explain the model, so they were withdrawn from the model through backward variable selection. To build this model, we used backwards variable selection regression based on Akaike Inference Criterion (AIC) using R (R Core Team, v. 3.5) and lme4 (Bates et al., 2015). 


\subsection{RESULTS}

\subsubsection{Blood Cell and biochemical parameters}

Beta-hydroxybutyrate concentration in the blood varied from 0.2 to $0.7 \mathrm{mmol} / \mathrm{L}$, but this variation was not significant for diet or infection status, neither it varied significantly overtime. Its concentration remained inside the normal values for the species (Ermilio and Smith, 2011).

On the fourth date, i.e., at the end of the experiment, a positive correlation among the number of red blood cells, haemoglobin and hematocrit were significant. Because haemoglobin values were positively correlated $(\mathrm{r}=0.96)$ with hematocrit, we opted for using only haemoglobin in the primordial follicle and oocyte size analysis to avoid redundancy and loss of statistical power. In the covariance analysis for haemoglobin as the dependent variable, diet and infection as categorical factors and plasma protein as a continuous predictor, plasma protein $(\mathrm{p}=0.002)$ and infection $(\mathrm{p}=0.000)$ influenced the haemoglobin levels.

Plasma protein varied significantly on the fourth date between Control and Supplemented protein diet groups on factorial ANOVA ( $\mathrm{p}=0.021$ - Figure 1). Plasma albumin levels did not vary significantly according to time, diet or infection (Figure 2). Glucose plasma concentration varied from 40.3 to $73.3 \mathrm{mg} / \mathrm{dL}$ on the four collection dates but also did not vary significantly with diet or infection status or with time(Figure 3). Its concentration remained inside the normal values for the species(Braun et al., 2010). Plasma urea levels varied significantly between different diets, infection status and interaction diet vs infection on the fourth date $(p=0.000, p=0.020, p=0.026$; Figure 4).

After the infection, haemoglobin levels varied significantly according to time (ANOVA repeated measures $\mathrm{p}=0.05$ ) between infected and not infected animals, with the not infected animals presenting higher levels of haemoglobin on the three subsequent dates. Haemoglobin also varied significantly on the fourth date when infection status was considered (factorial ANOVA p=0.005; Figure 5).

The number of red blood cells did not significantly vary on the first dates, on the third and fourth date though, the number of red blood cells varied significantly with infection status (respectively $\mathrm{p}=0.032$ and $\mathrm{p}=0.00026$; Figure 6).

Regarding white blood cell counts, the number of monocytes was significantly higher in the Control infected group on the second date but was not in the other dates (Figure 7). On the fourth date, the number of neutrophils was significantly higher in the supplemented protein groups (factorial ANOVA $p=0.030$; Figure 8). Also, on the fourth date the number of lymphocytes in the control protein groups was higher (factorial ANOVA p $=0.044$; Figure 9).

\subsubsection{Number of Haemonchus contortus eggs in the faeces}

Ewe lambs that were not artificially infected with H. contortus larvae remained free of helminth eggs in their faeces through the four dates of faeces collection. In the supplemented infected group, the number of eggs varied from 0 to 3,350(average of 657). In the control infected group, the number of eggs varied from 0 to 5,400(average of 1,385). But there was no significant difference between protein supplemented and not supplemented infected groups for the number of $\mathrm{H}$. contortus eggs in the faeces.

\subsubsection{AMH serum levels}

Serum AMH concentrations ranged from $0.12 \mathrm{ng} / \mathrm{mL}$ to $1.29 \mathrm{ng} / \mathrm{mL}$ on the first date(mean 0.86, std.dev. 0,3), 0.52 to $1.45 \mathrm{ng} / \mathrm{mL}$ on the second date (mean 0.9, std. dev.0.29), 0.43 to $2.02 \mathrm{ng} / \mathrm{mL}$ (mean 1.13, std.dev. 0.45) and 0.41 to $1.31 \mathrm{ng} / \mathrm{mL}$ on the fourth date (mean 0.79, std.dev. 0.24) (Figure 10). There was great variation in the 
concentration among individuals. However, the variation was not significant between different levels of protein in the diet, infection status, interaction diet vs infection, age, or progression of time during the experiment. Although not significant, there was a consistent variation in the average levels of AMH in all groups in the third date. The averages were higher than the other dates, and on the fourth date, they lowered again (Figure 11).

There was no correlation of serum AMH levels among different dates even though these measurements were made with short intervals between them, confirming a variation of AMH's concentration in the same cycle of the same animal. On a significance level, though, AMH did not vary significantly in the same animal during the same oestrus cycle (ANOVA repeated measures).

Serum AMH covariates with plasma protein on the fourth date when level of protein in the diet was considered $(\mathrm{p}=0.013)$. AMH covariates with the number of red blood cells on the third $(\mathrm{p}=0.036)$ and fourth date $(p=0.001)$, when infection status was considered. Plasma albumin covariates with AMH on the fourth date when infection status was considered $(\mathrm{p}=0.048)$. Plasma haemoglobin covariates with $\mathrm{AMH}$ on the fourth date when infection status was considered $(\mathrm{p}=0.004)$.

\subsubsection{Size of ovarian primordial follicles and oocytes}

The statistic model was significant for the primordial follicle and oocyte size's average size $(p<.0001)$. There was a significant correlation $(\mathrm{r}=0.85)$ between the oocyte and primordial follicle sizes.

Primordial follicle size significantly varied due to the interaction diet vs infection status on factorial ANOVA $(p=0.037)$ and due to different levels of protein in the diet $(p<.0001)$, where supplemented not infected group presented larger sizes (Figure 12). Primordial follicle size also covaried significantly with plasma protein (continuous predictor) on the 4 th date $(\mathrm{p}=0.039)$ when the diet as a categorical factor was considered. Accordingly, in a multiple regression analysis, the primordial follicle size related to plasma protein level (p-level 0.009945; Beta $0,702875)$.

On the comparison of primordial follicles sizes between ewe lambs fed with supplemented protein and supplemented protein infected $(\mathrm{p}=0.0018)$ and between those fed with supplemented protein vs control protein a significative (<.0001) difference was found. There was also a difference between the groups control protein and control protein infected $(\mathrm{p}=0.0053)$.

Oocyte size significantly varied with the level of protein in the diet, with supplemented groups presenting a larger size (factorial ANOVA p=0.047; Figure 12).

For the number of normal antral follicles, the interaction between Diet and Infection status was significative $(\mathrm{p}=0.023)$ and, so it was for the number of atretic antral follicles $(\mathrm{p}=0.041)$.

\subsubsection{Model of physiological influence on oocyte' and primordial follicle' sizes}

\subsubsection{Explanatory model for oocyte size}

The model which best explained (Best fit model) the significant variation in oocyte size was the one that included: the interaction of Diet and Infection status, the level of plasma protein, albumin, haemoglobin, AMH, glucose, beta-hydroxybutyrate, number of neutrophils and monocytes as fixed effects and age as a random effect. This model was significative (Chisquare $=161.8$; p-value $<2.2 \mathrm{e}-16$ ) when compared to a more parsimonious model, which included the interaction of Diet and Infection status, serum AMH, plasma protein, haemoglobin as fixed effects and age as a random effect (Chisquare $=9.1843 ; \mathrm{p}$-value $=0.027$ ). The Best fit model was also significative compared to the model, which included only the interaction of Diet and Infection status as fixed effects and age as a random effect 
(Null model). This best fit model had the lowest Akaike Information Criterion(AIC $=-105.37$ ) compared to both models above(Table 4).

Table 4. Results of linear mixed model analysis for the physiological influence on oocyte size

\begin{tabular}{|c|c|c|c|c|c|c|c|c|c|c|}
\hline & npar & AIC & BIC & logLik & deviance & Chisq & Df & $\Delta \mathrm{AIC}$ & rank & $\operatorname{Pr}(>$ Chisq $)$ \\
\hline Best fit model & 14 & -105.370 & -93.705 & 66.685 & -133.370 & 161.8 & 5 & 0 & $1 \mathrm{st}$ & $<2.2 \mathrm{e}-16$ \\
\hline Parsimonious model & 9 & 46.425 & 53.924 & -14.213 & 28.425 & 9.18 & 3 & 151.8 & 2nd & 0.02694 \\
\hline Null model & 6 & 49.610 & 54.609 & -18.805 & 37.610 & & & 155 & $3 \mathrm{rd}$ & \\
\hline
\end{tabular}

$*_{\text {npar }}=$ number of parameters included in the model; AIC = Akaike Information Criterion; BIC = Bayesian Information Criterion; loglik= log likelihood; Df=degrees of freedom; Chisq= Chisquare; $\operatorname{Pr}(>$ Chisq $)=p$-value

\subsubsection{Explanatory model for primordial follicle size}

For the primordial follicle size, the Best fit model explaining its variation was the one that included the interaction of Diet and Infection status, the level of plasma protein, albumin, haemoglobin, AMH, glucose, number of lymphocytes as fixed effects and age as a random effect. The best fit model was significative compared to the parsimonious model including the interaction of Diet and Infection status, serum AMH, plasma protein and haemoglobin as fixed effects and age as a random effect (Chisq $=158.7$; p-value $<2.2 \mathrm{e}-16)$. The best fit model was also significative when compared to the model which included only the interaction of Diet and Infection status as fixed effects and age as a random effect (Chisq $=171.39 ; \mathrm{p}$-value $=<2.2 \mathrm{e}-16)$. This best fit model had the lowest Akaike Information Criterion (AIC $=-109.245)$ compared to both models above (Table 5).

Table 5. Results of linear mixed model analysis for the physiological influence on primordial follicle size

\begin{tabular}{lcccccccccc}
\hline & npar & AIC & BIC & logLik & deviance & Chisq & df & $\Delta$ AIC & rank & $\operatorname{Pr}(>$ Chisq) \\
\hline Best fit model & 12 & -109.245 & -99.246 & 66.622 & -133.245 & 158.7 & 3 & 0 & 1 & $<2.2 \mathrm{e}-16$ \\
Parsimonious model & 9 & 43.453 & 50.952 & -12.726 & 25.453 & 12.69 & 3 & 152.7 & 2 & 0.005357 \\
Null model & 6 & 50.143 & 55.142 & -19.071 & 38.143 & & & 159.4 & 3 & \\
\end{tabular}

${ }_{\text {*npar }}=$ number of parameters included in the model; AIC = Akaike Information Criterion; BIC = Bayesian Information Criterion; loglik $=\log$ likelihood; Df=degrees of freedom; Chisq $=$ Chisquare; $\operatorname{Pr}(>$ Chisq $)=p$-value 

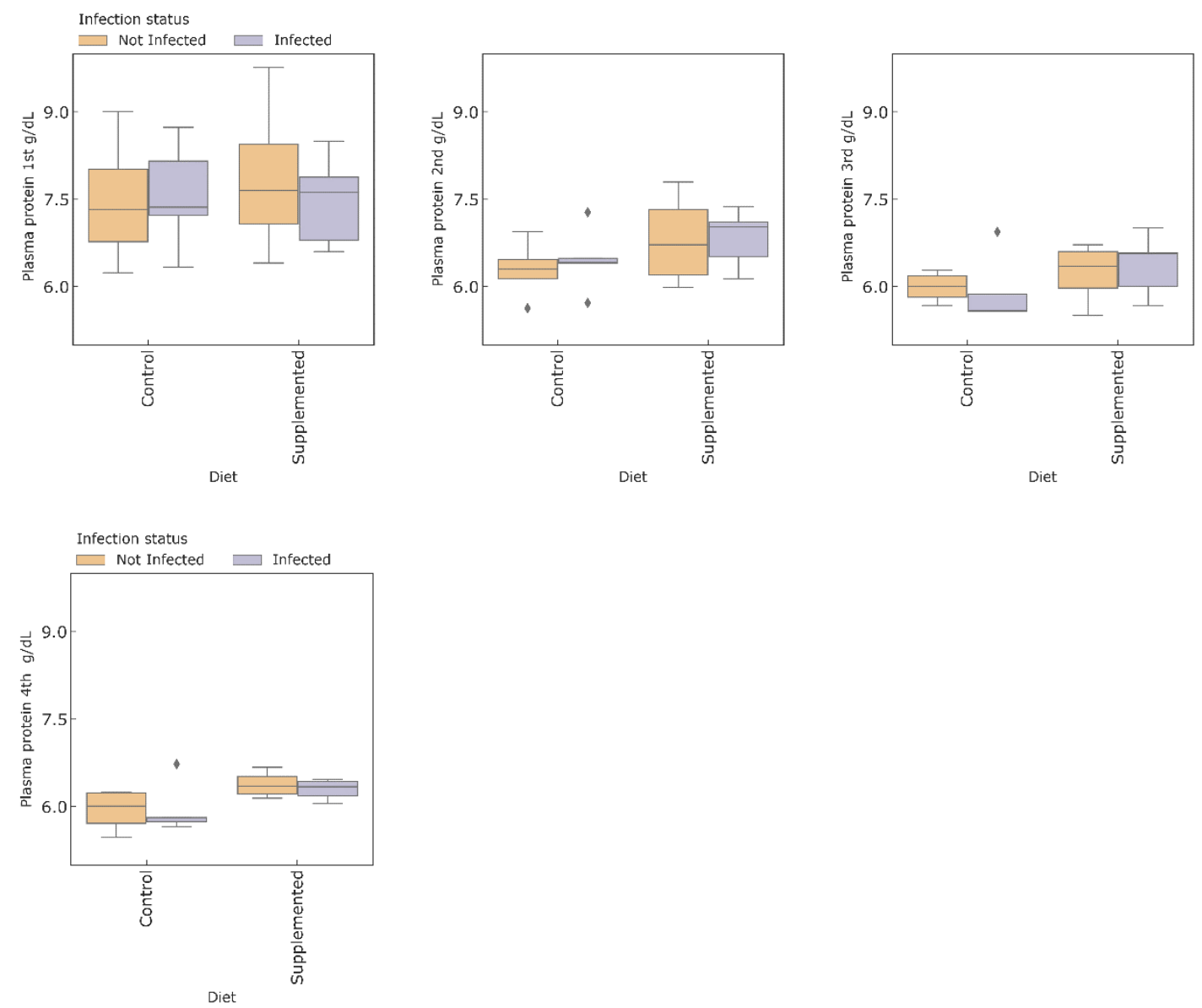

Figure 1. Plasma protein level in the groups Control not Infected, Control Infected, Supplemented not Infected and Supplemented Infected on four consecutive dates throughout the experiment. Plasma protein level varied significantly due to different level of dietetic protein $(\mathrm{p}=0.02)$ on the fourth $\left(4^{\text {th }}\right)$ date. 

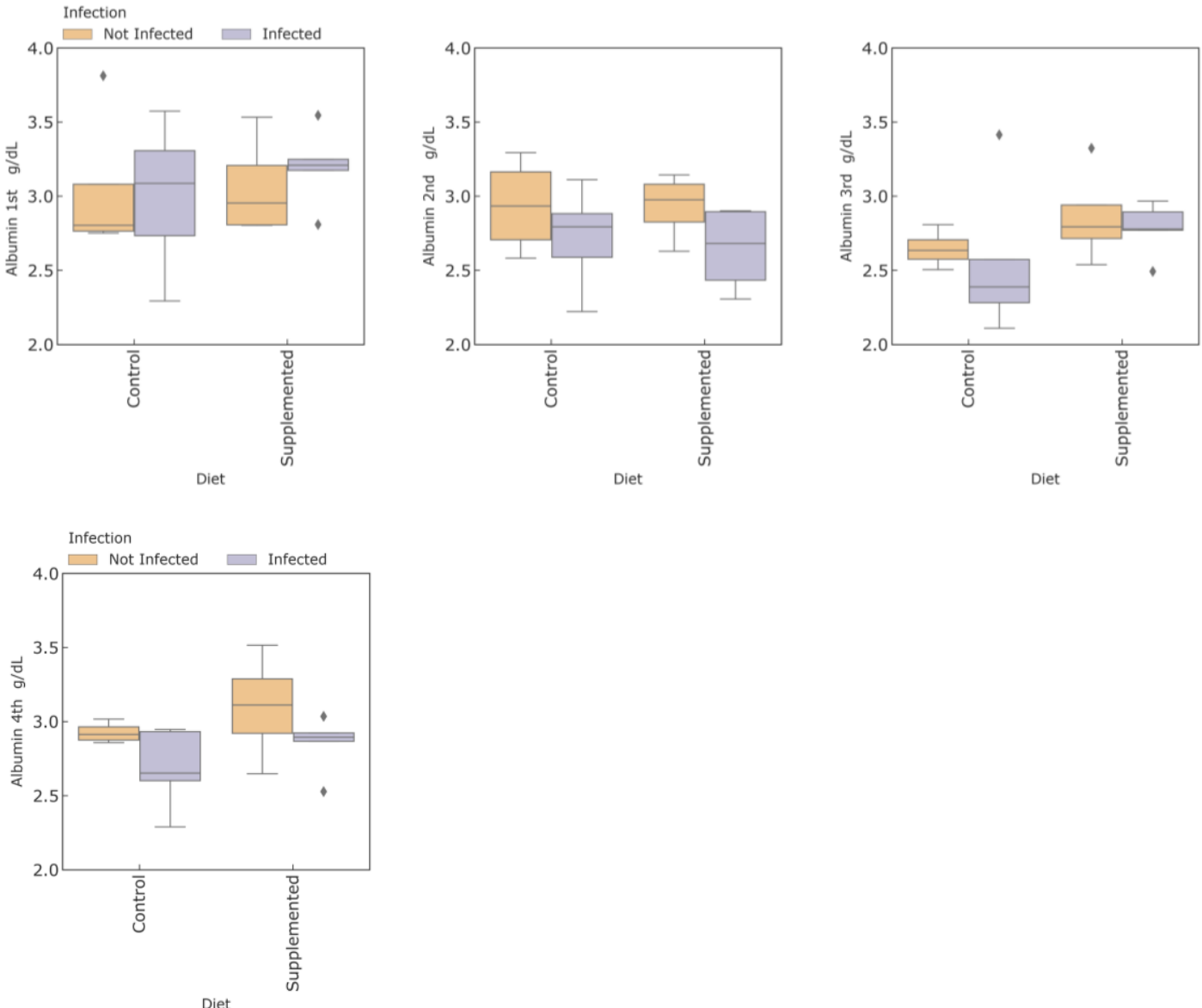

Figure 2. Albumin levels in the groups Control not Infected, Control Infected, Supplemented not Infected and Supplemented Infected on four consecutive dates throughout the experiment. Albumin levels did not vary significantly.

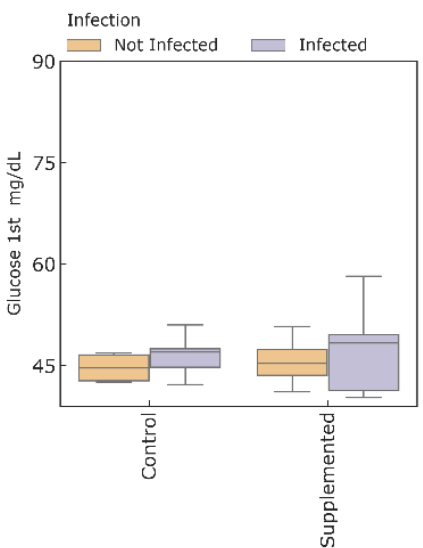

Diet

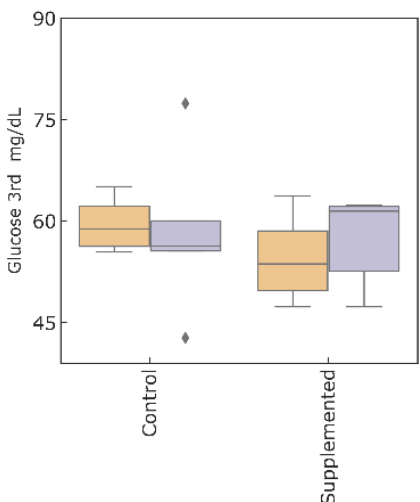

Diet

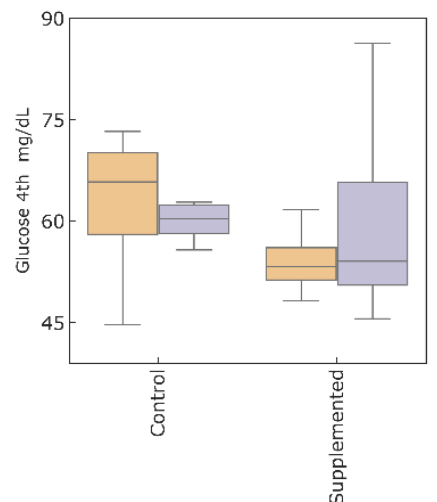

Diet

Figure 3. Glucose levels in the groups Control not Infected, Control Infected, Supplemented not Infected and Supplemented Infected on first(1st), third(3rd) and fourth(4th) dates throughout the experiment. Glucose levels did not vary significantly. 

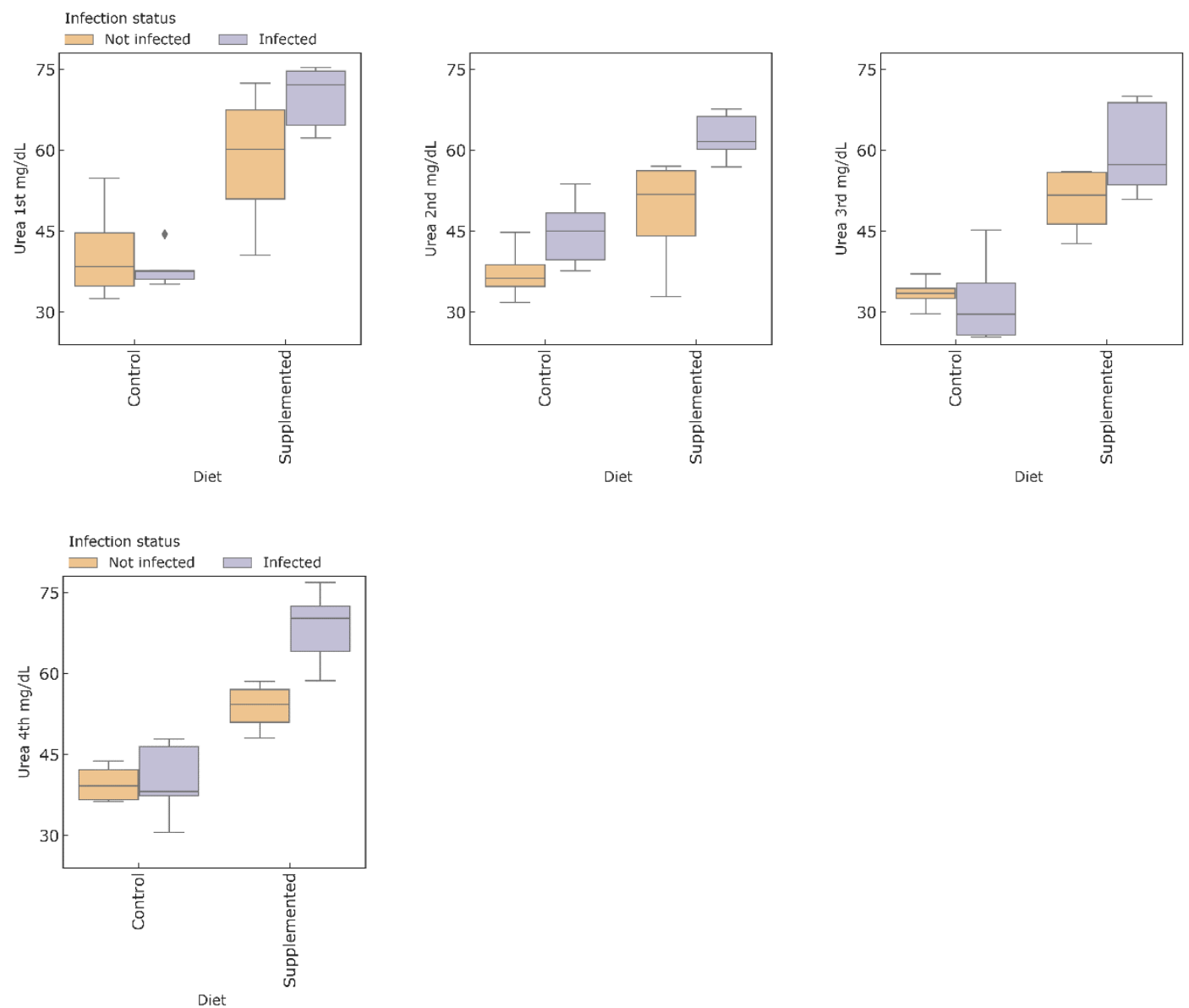

Figure 4. Plasma urea levels in the groups Control not Infected, Control Infected, Supplemented not Infected and Supplemented Infected on four consecutive dates throughout the experiment. Plasma urea levels varied significantly between different diets, different infection status and due to the interaction diet vs infection on the fourth $\left(4^{\text {th }}\right)$ date $(\mathrm{p}=0.000, \mathrm{p}=0.020, \mathrm{p}=0.026)$. 

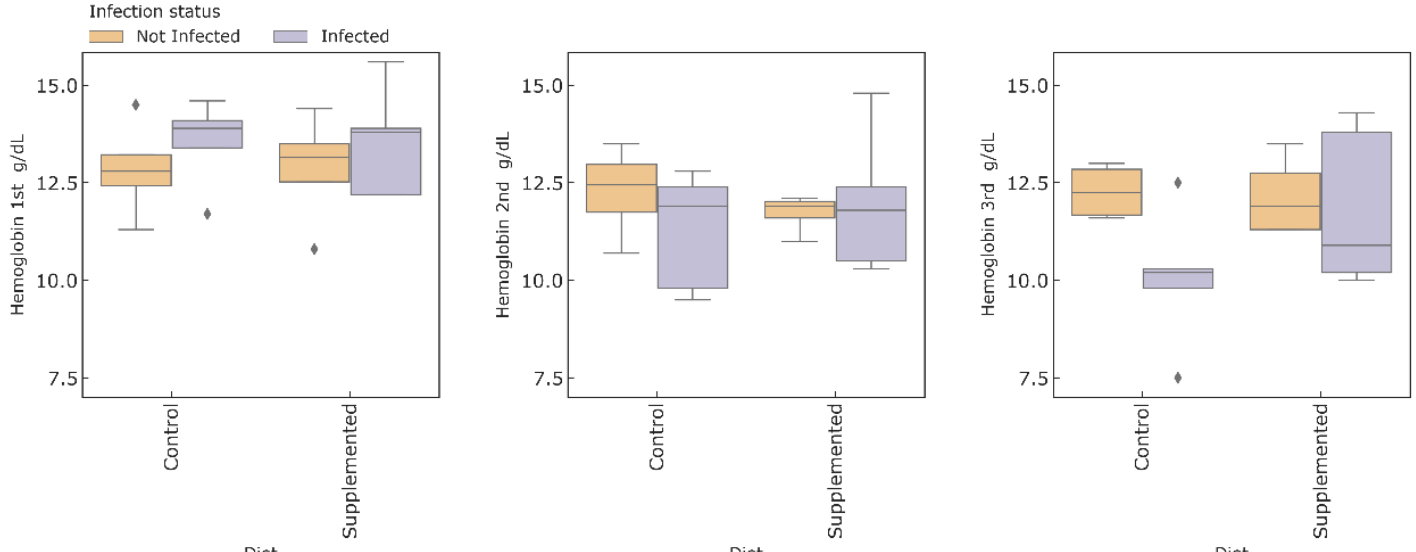

Diet

Diet

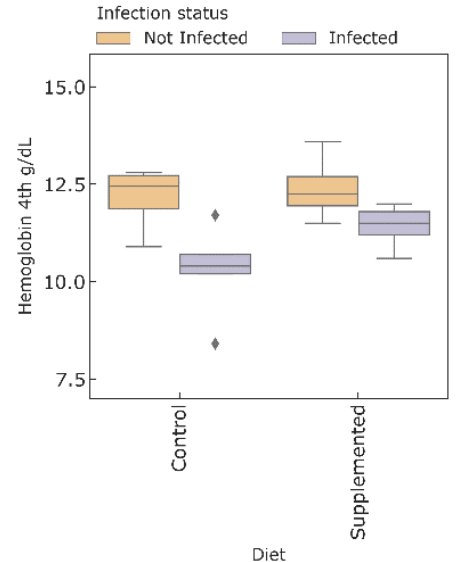

Figure 5. Haemoglobin levels in the groups Control not Infected, Control Infected, Supplemented not Infected and Supplemented Infected on four consecutive dates throughout the experiment. Haemoglobin levels after the infection varied significantly overtime $(\mathrm{p}=0.05)$ between infected and not infected animals. Haemoglobin varied significantly on the fourth $\left(4^{\text {th }}\right)$ date due to different infection status (factorial ANOVA $\mathrm{p}=0.005$ ). 

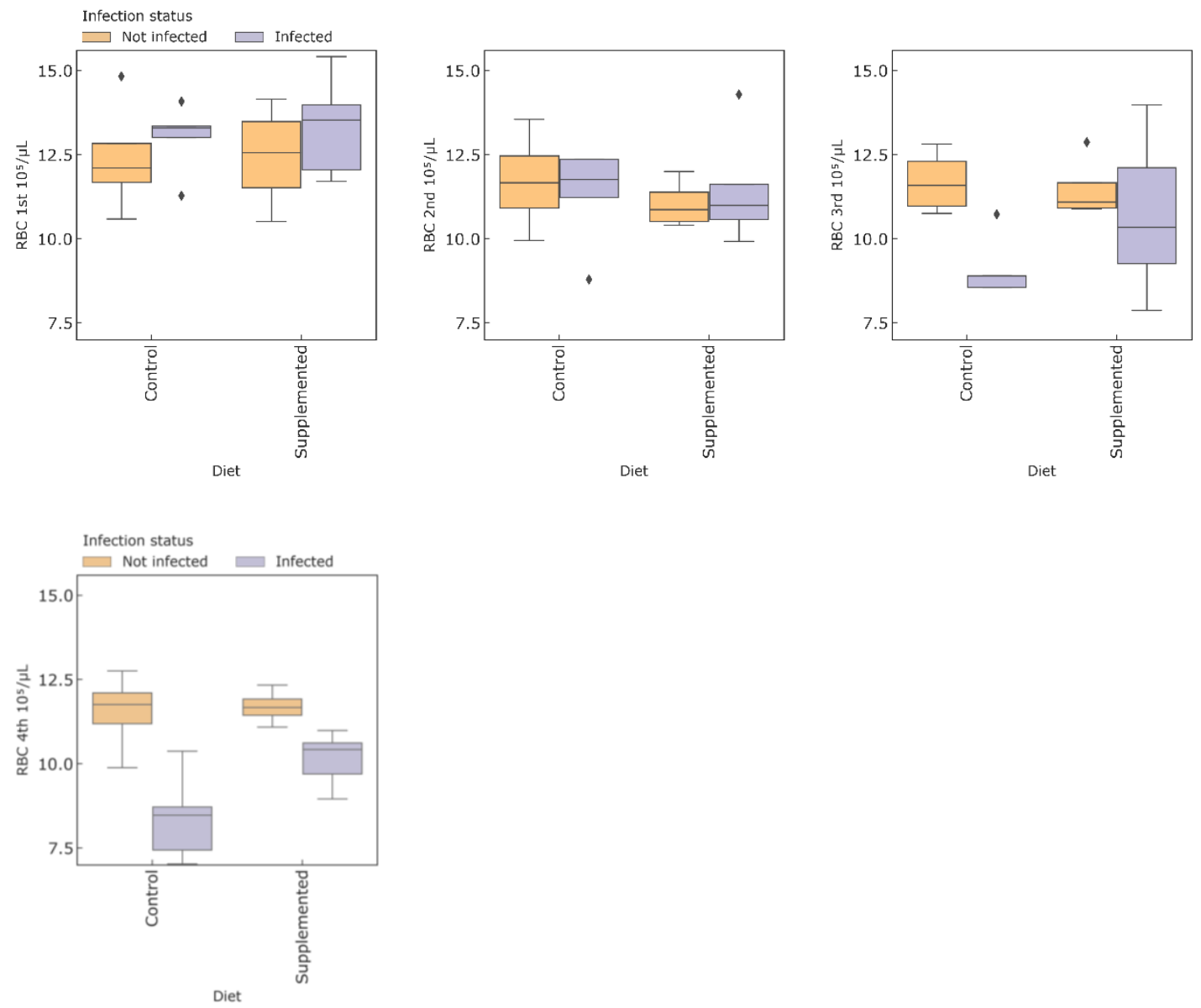

Figure 6. Number of red blood cells $\left(\mathrm{RBC}-10^{5} / \mu \mathrm{L}\right)$ in the groups Control not Infected, Control Infected, Supplemented not Infected and Supplemented Infected on four consecutive dates throughout the experiment. On the third(3rd) and fourth(4th) date the number of red blood cells varied significantly due to different infection status (respectively $\mathrm{p}=0.032$ and $\mathrm{p}=0.00026$ ) 

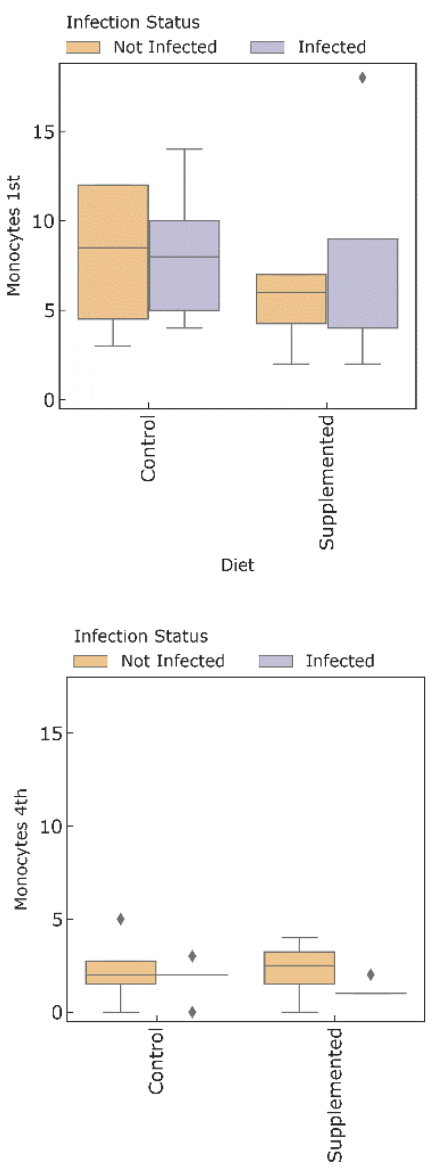

Diet

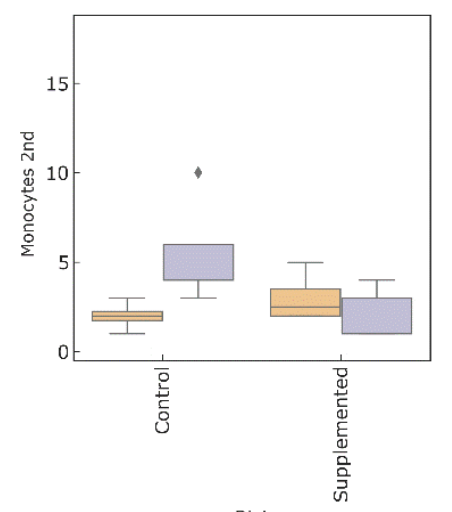

Diet

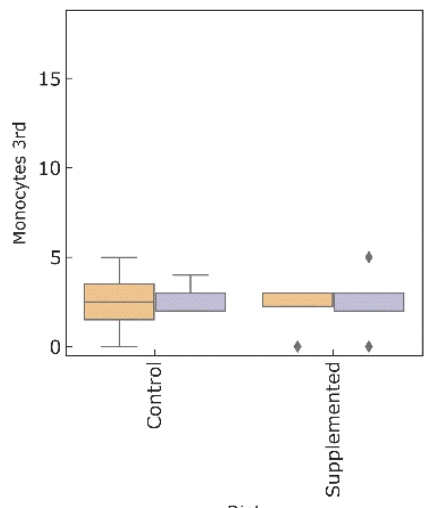

Diet

Figure 7. Number of monocytes in the groups Control not Infected, Control Infected, Supplemented not Infected and Supplemented Infected on four consecutive dates throughout the experiment. The number of monocytes varied due to the interaction diet vs infection $(\mathrm{p}=0.036)$ on the second $\left(2^{\text {nd }}\right)$ date. 


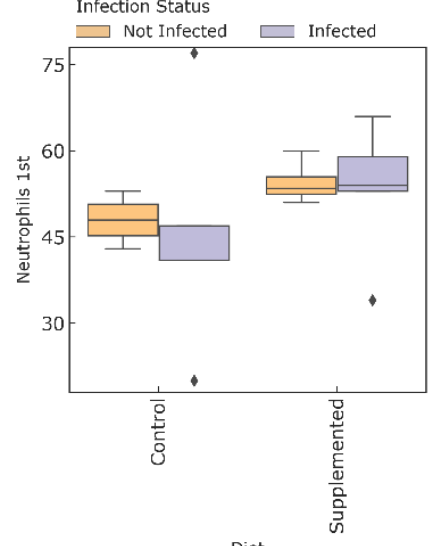

Diet

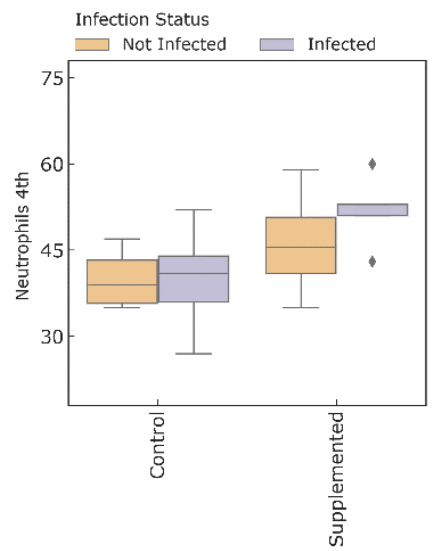

Diet

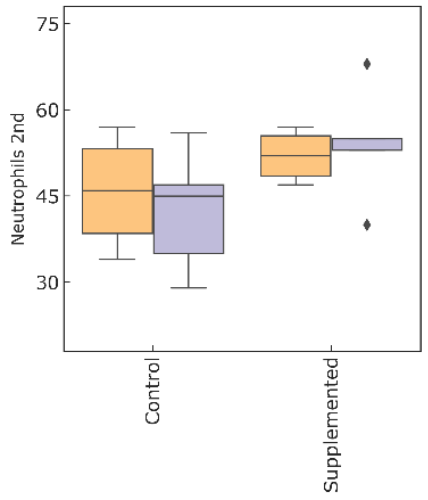

Diet

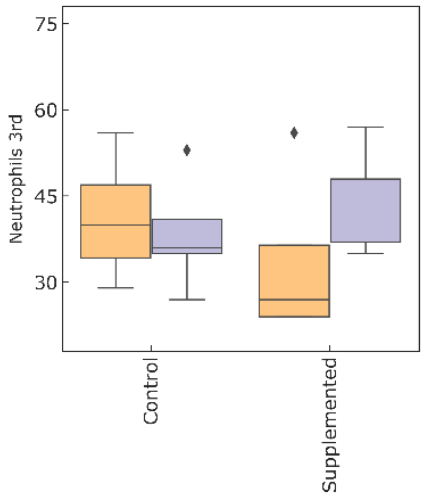

Diet

Figure 8. Number of neutrophils in the groups Control not Infected, Control Infected, Supplemented not Infected and Supplemented Infected on four consecutive dates throughout the experiment. the number of neutrophils was significantly higher in the supplemented protein groups $(\mathrm{p}=0.030)$ on the fourth $\left(4^{\text {th }}\right)$ date 


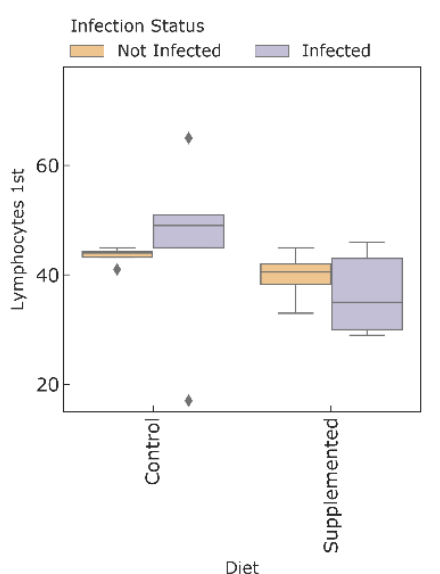

Infection Status

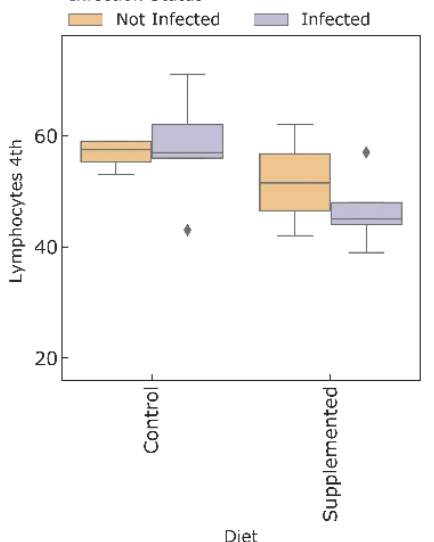

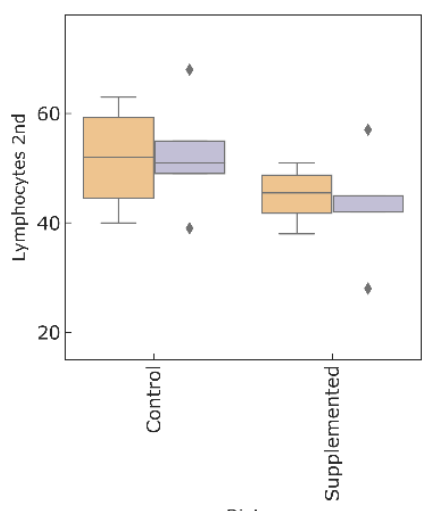

Diet

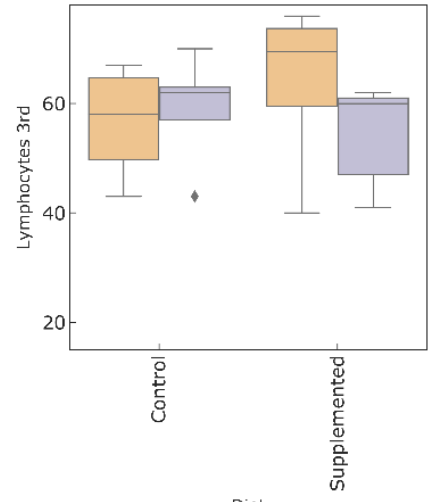

Diet

Figure 9. Number of lymphocytes in the groups Control not Infected, Control Infected, Supplemented not Infected and Supplemented Infected on four consecutive dates throughout the experiment. The number of lymphocytes varied significantly due to different protein levels in the $\operatorname{diet}(\mathrm{p}=0.044)$ on the fourth date $\left(4^{\text {th }}\right)$. 

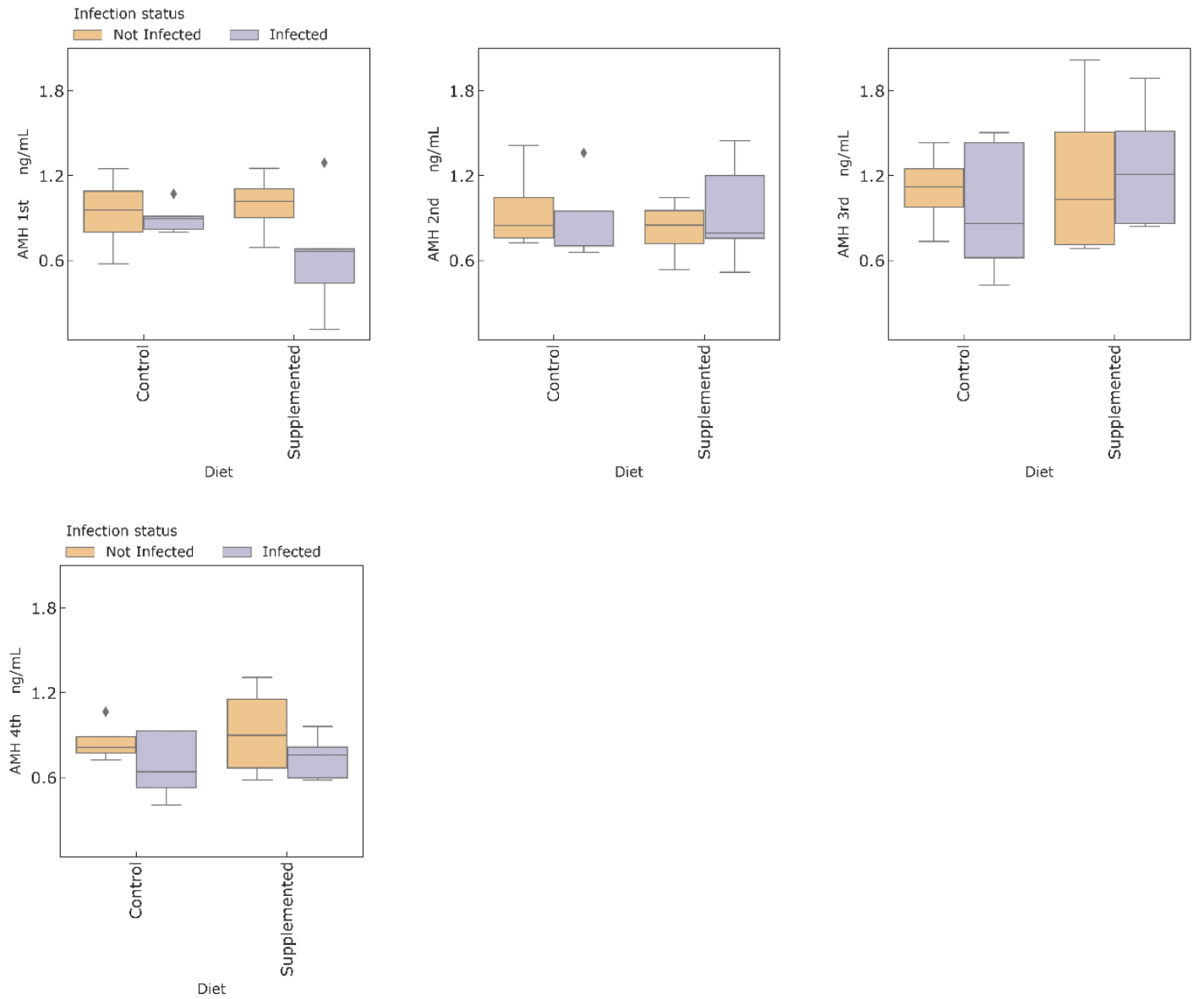

Figure 10. AMH concentrations in $\mathrm{ng} / \mathrm{mL}$ in the groups Control not Infected, Control Infected, Supplemented not Infected and Supplemented Infected on four consecutive dates throughout the experiment.

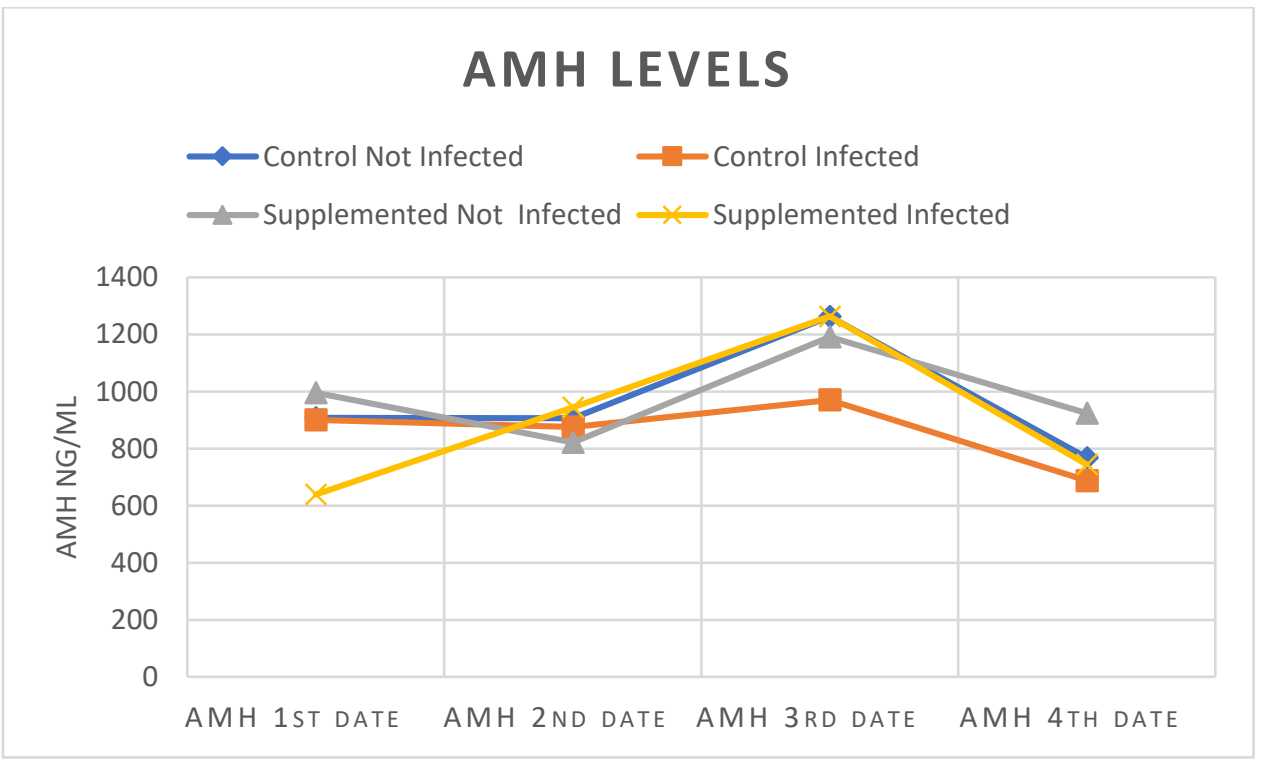

Figure 11. Average levels of serum AMH concentration(picograms $/ \mathrm{mL}$ ) on the four experimental dates in the groups Control Not Infected, Control Infected, Supplemented Not Infected and Supplemented Infected. 

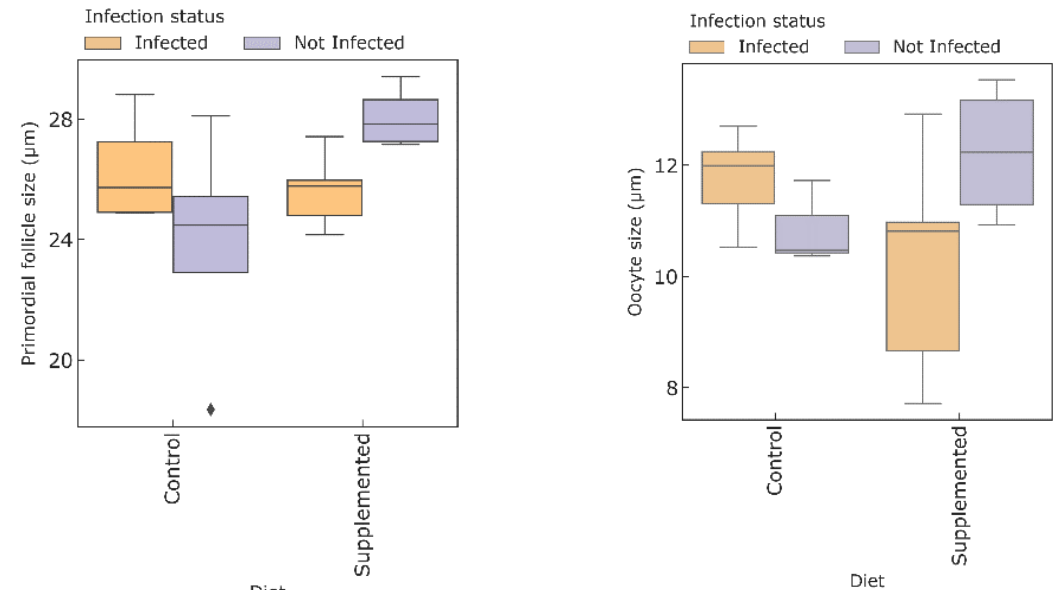

Figure 12. Size of primordial follicle and oocyte size in ewe lambs Control Protein Not Infected, Supplemented not infected, Control Protein infected and Supplemented Protein Infected.Oocyte size varied significantly due to different dietetic protein level $(\mathrm{p}=0.047)$. Primordial follicle size significantly varied due to the interaction diet $\mathrm{x}$ infection status $(\mathrm{p}=0.037)$ and due to different levels of dietetic protein $(\mathrm{p}<.0001)$. 


\subsection{DISCUSSION}

Plasma protein was significantly higher in animals supplemented with protein in the diet, meaning that these animals had more circulating protein than their low protein diet counterparts. Haemoglobin and red blood cells were significantly lower in the infected animals, an expected response to the Haemonchus contortus infection, which causes blood loss and anaemia. Although the Control infected animals presented lower plasma protein levels and haemoglobin, they were in the normal range for the species. The supplemented not infected animals had normal blood parameters; their plasma urea was not significantly higher than the supplemented infected animals. According to this and their glucose levels, the not infected animals could cope with their diet's extra protein.

Serum AMH did not significantly vary with ewe lambs' age, body weight, abomasal infection, neither with the progression of time during the experimental period, a surprising fact, considering that the ewe lambs were in transition to the pubertal period when body growth and reproductive development are intense. So, during our experiment, AMH functioned as a stable measurement of the ovarian reserve, what is in agreement with some of the literature in cows (Ireland et al., 2011; Rico et al., 2009) but disagrees with a study in humans which found high variability of AMH in the same women's ovarian cycles and between their cycles (Melado et al., 2018).

The concentration levels of AMH in all our ewe lambs were greater than $120 \mathrm{pg} / \mathrm{mL}$ what is higher than the stipulated value of $97 \mathrm{pg} / \mathrm{mL}$ by (Lahoz et al., 2012) used as a screening cutoff value in 3.6 months old ewe lambs, to predict fertility at first mating. The synchronous raise in the average AMH concentration in all groups on the third date and its fall on the fourth date could be an indication that these animals were in the same ovarian developmental period, as it was seen in the AMH profile of prepubertal heifers (Ali et al., 2017). On the third date (60 days of diet and 30 days post-infection) and fourth experimental date (67 days of diet and 37 days post-infection) the averages of the group that was infected and not supplemented with protein (Control Infected group) were lower than in the other groups.

The significant covariance found between AMH with plasma protein, albumin, and haemoglobin shows an influence of AMH on these parameters. In the covariance analysis, AMH increases the significance (lowers the p-value) of these physiological parameters when the infection is present. The explanatory linear mixed model for the size of oocyte and size of primordial follicle confirms these findings. When AMH is included as a fixed effect, the model's explicability is significatively higher than without AMH. A possible explanation is that circulating AMH could be contributing to set the animals' reproductive context to the overall homeostasis.

We expected that the plasma protein levels in the ewe lamb's blood would impact the primordial follicle size and oocyte size because the primordial follicle activation is susceptible to the nutrients level in the ovary microenvironment to transition into a primary follicle. MTORC1 is a gene pathway that integrates environmental signals to control cell growth and metabolism and is a sensor for amino acids levels (Nguyen et al., 2017; Tan and Miyamoto, 2016). The high levels of amino acids activate MTORC1 signalling in the granulosa cells and this signalling awakens the oocyte (Liu et al., 2014b; Zhang, Hua; Liu, 2015) and a super activation of mTORC1 signaling in dormant oocytes accelerates the activation of primordial follicles (Adhikari et al., 2009). 
Our hypothesis for the influence of physiological factors on oocyte and follicle sizes was a parsimonious model that considered only plasma protein, haemoglobin and serum AMH. However, the findings show that a more complex model, including other parameters such as immune cells, was necessary to explain these ovarian parameters' variation.

The physiological influence model that best explained the variation in oocyte size had different variables to the model that best explained primordial follicle size. These difference in variables could have a relationship with the findings that oocyte size varied significantly only with protein level in the diet, and primordial follicle size varied significantly with plasma protein level and with the interaction of diet and infection status in initial variance analysis.

The two models differed. Including beta-hydroxybutyrate (BHB), neutrophils and monocytes, increased the oocyte size model's explicability and, including only lymphocytes, increased the explicability for the primordial follicle model.

High levels of beta-hydroxybutyrate in follicular fluid and blood of postpartum cows were linked to worse embryonic development and subnormal Corpus luteum function (Jorritsma et al., 2004). However, in our animals, there were no high levels of BHB neither a significative difference among the groups. So, probably the animals were in energetic balance.

Regarding the inclusion of immune cells in the models, there is no direct evidence that circulating immune cells could access and act in the ovarian tissue. However, there is knowledge of an immune cell population resident in the ovary that plays a role in the remodelling and maintenance of ovarian tissue and even regeneration of ovarian follicles (Bukovsky, 2011; Richards et al., 1998; Wagner et al., 2020).Moreover, in polycystic ovarian syndrome - an endocrine-reproductive-metabolic disorder - there is a hormone-mediated dysregulation of immune cells (Hu et al., 2020).

In this physiological context formed by the extra dietetic protein, abomasal infection and peripubertal development, the immune cells could be representing other physiological factors in the model that were not measured.

The complexity of the explanatory model reflects the multiple interactions occurring in the organism during the pubertal period. Primordial follicles activation is genuinely dependent on the general homeostasis and not only on few physiological parameters. Supplemented not infected animals had significantly larger primordial follicle and oocyte sizes than other groups, but the average size of the other three groups were similar. So maybe a higher supplementation of protein in the peripubertal period might be necessary when there is a gastrointestinal disease by Haemonchus contortus infection. By supplementing protein to infected animals, we are giving extra support to their homeostasis and enabling them to activate their follicles, reaching puberty in a timely fashion. 


\section{REFERENCES}

Abecia, J.A.A., Lozano, J.M.M., Forcada, F., Zarazaga, L., 1997. Effect of level of dietary energy and protein on embryo survival and progesterone production on day eight of pregnancy in Rasa Aragonesa ewes. Anim. Reprod. Sci. 48, 209-218.

Adhikari, D., Flohr, G., Gorre, N., Shen, Y., Yang, H., Lundin, E., Lan, Z., Gambello, M.J., Liu, K., 2009. Disruption of Tsc2 in oocytes leads to overactivation of the entire pool of primordial follicles. Mol. Hum. Reprod. 15, 765770. https://doi.org/10.1093/molehr/gap092

Ali, H.E.S., Kitahara, G., Takahashi, T., Mido, S., Sadawy, M., Kobayashi, I., Hemmi, K., Osawa, T., 2017. Plasma anti-Müllerian hormone profile in heifers from birth through puberty and relationship with puberty onset. Biol. Reprod. 97, 153-161. https://doi.org/10.1093/biolre/iox069

Balic, A., Bowles, V.M., Meeusen, E.N.T., 2000. The immunobiology of gastrointestinal nematode infections in ruminants. Adv. Parasitol. 45, 181-241. https://doi.org/10.1016/S0065-308X(00)45005-0

Batista, E.O.S., Vieira, L.M., Freitas, B.G., Guerreiro, B.M., Carvalho, J.G.S., Mingoti, R.D., Vasconcellos, G., Souza, A.H., Bento Sterman Ferraz, J., Sampaio Baruselli, P., 2020. Anti-Mullerian hormone and its relationship to ovulation response and fertility in timed AI Bos indicus heifers. Reprod. Domest. Anim. 55, 753-758. https://doi.org/10.1111/rda.13677

Berardinelli, J.G., Weng, J., Burfening, P.J., Adair, R., 1998. Effect of excess degradable intake protein on early embryonic development, ovarian steroids, and blood urea nitrogen on days $2,3,4$, and 5 of the estrous cycle in mature ewes 1 193-199.

Bezerra, M.É.S., Barberino, R.S., Menezes, V.G., Gouveia, B.B., Macedo, T.J.S., Santos, J.M.S., Monte, A.P.O., Barros, V.R.P., Matos, M.H.T., 2018. Insulin-like growth factor-1 (IGF-1) promotes primordial follicle growth and reduces DNA fragmentation through the phosphatidylinositol 3-kinase/protein kinase B (PI3K/AKT) signalling pathway. Reprod. Fertil. Dev. 30, 1503-1513. https://doi.org/10.1071/RD17332

Braun, J.P., Trumel, C., Bézille, P., 2010. Clinical biochemistry in sheep: A selected review. Small Rumin. Res. 92, 1018. https://doi.org/10.1016/j.smallrumres.2010.04.002

Bukovsky, A., 2011. Immune Maintenance of Self in Morphostasis of Distinct Tissues, Tumour Growth and Regenerative Medicine. Scand. J. Immunol. 73, 159-189. https://doi.org/10.1111/j.1365-3083.2010.02497.x

Campbell, B.K., Telfer, E.E., Webb, R., Baird, D.T., 2004. Evidence of a Role for Follicle-Stimulating Hormone in Controlling the Rate of Preantral Follicle Development in Sheep. Endocrinology 145, 1870-1879. https://doi.org/10.1210/en.2003-1138

Coles, G.C., Bauer, C., Borgsteede, F.H.M., Geerts, S., Klei, T.R., Taylor, M.A., Waller, P.J., 1992. World Association for the Advancement of Veterinary Parasitology (W.A.A.V.P.) methods for the detection of anthelmintic resistance in nematodes of veterinary importance. Vet. Parasitol. 44, 35-44. https://doi.org/10.1016/03044017(92)90141-U

Durlinger, A.L.L., Gruijters, M.J.G., Kramer, P., Karels, B., Ingraham, H.A., Nachtigal, M.W., Uilenbroek, J.T.J., Anton Grootegoed, J., Themmen, A.P.N., 2002. Anti-Müllerian hormone inhibits initiation of primordial follicle growth in the mouse ovary, Endocrinology. https://doi.org/10.1210/endo.143.3.8691

Ermilio, E.M., Smith, M.C., 2011. Treatment of Emergency Conditions in Sheep and Goats. Vet. Clin. North Am. Food Anim. Pract. 27, 33-45. https://doi.org/10.1016/j.cvfa.2010.10.005 
H. Hoste, J.F.J. Torres-Acosta J. Quijada, I. Chan-Perez, M.M. Dakheel, D.S. Kommuru, I. Mueller-Harvey, T.H.T., 2017. Advances in Parasitology. pp. 570-576.

Hirayama, H., Naito, A., Fukuda, S., Fujii, T., Asada, M., Inaba, Y., Takedomi, T., Kawamata, M., Moriyasu, S., Kageyama, S., 2017. Long-term changes in plasma anti-Müllerian hormone concentration and the relationship with superovulatory response in Japanese Black cattle. J. Reprod. Dev. 63, 95-100. https://doi.org/10.1262/jrd.2016-019

Hirshfield, A.N., 1991. Development of Follicles in the Mammalian Ovary. Int. Rev. Cytol. 124, 43-101. https://doi.org/10.1016/S0074-7696(08)61524-7

Houdijk, J.G.M., 2012. Differential effects of protein and energy scarcity on resistance to nematode parasites. Small Rumin. Res. 103, 41-49. https://doi.org/10.1016/j.smallrumres.2011.10.017

Houdijk, J.G.M., Jessop, N.S., Kyriazakis, I., 2001. Nutrient partitioning between reproductive and immune functions in animals. Proc. Nutr. Soc. 60, 515-525. https://doi.org/10.1079/PNS2001114

Houdijk, J.G.M., Kyriazakis, I., Jackson, F., Huntley, J.F., Coop, R.L., 2005. Effects of protein supply and reproductive status on local and systemic immune responses to Teladorsagia circumcincta in sheep. Vet. Parasitol. 129, 105117. https://doi.org/10.1016/j.vetpar.2004.12.023

Hu, C., Pang, B., Ma, Z., Yi, H., 2020. Immunophenotypic profiles in polycystic ovary syndrome. Mediators Inflamm. 2020. https://doi.org/10.1155/2020/5894768

Ireland, J.J., Smith, G.W., Scheetz, D., Jimenez-Krassel, F., Folger, J.K., Ireland, J.L.H., Mossa, F., Lonergan, P., Evans, A.C.O., 2011. Does size matter in females? An overview of the impact of the high variation in the ovarian reserve on ovarian function and fertility, utility of anti-Mullerian hormone as a diagnostic marker for fertility and causes of variation in the ovarian reserve in . Reprod. Fertil. Dev. 23, 1-14. https://doi.org/10.1071/RD10226

Jackson, F., Varady, M., Bartley, D.J., 2012. Managing anthelmintic resistance in goats-Can we learn lessons from sheep? Small Rumin. Res. 103, 3-9. https://doi.org/10.1016/j.smallrumres.2011.10.012

Jiang, J.Y., Macchiarelli, G., Tsang, B.K., Sato, E., 2003. Capillary angiogenesis and degeneration in bovine ovarian antral follicles. Reproduction 125, 211-223.

Jorritsma, R., César, M.., Hermans, J.,, Kruitwagen, C.L.J., Vos, P.L.A.., Kruip, T.A.., 2004. Effects of non-esterified fatty acids on bovine granulosa cells and developmental potential of oocytes in vitro. Anim. Reprod. Sci. 81, 225235. https://doi.org/10.1016/J.ANIREPROSCI.2003.10.005

Kahn, L.P., 2003. Regulation of the resistance and resilience of periparturient ewes to infection with gastrointestinal nematode parasites by dietary supplementation. Aust. J. Exp. Agric. https://doi.org/10.1071/EA02202

Lahoz, B., Alabart, J.L., Monniaux, D., Mermillod, P., Folch, J., 2012. Anti-Müllerian hormone plasma concentration in prepubertal ewe lambs as a predictor of their fertility at a young age. BMC Vet. Res. 8, 1. https://doi.org/10.1186/1746-6148-8-118

Liu, K., Zhang, H., Risal, S., Gorre, N., Busayavalasa, K., Li, X., Shen, Y., Bosbach, B., Brännström, M., 2014. Somatic cells initiate primordial follicle activation and govern the development of dormant oocytes in mice. Curr. Biol. 24, 2501-2508. https://doi.org/10.1016/i.cub.2014.09.023

Louvandini, H., Veloso, C.F.M., Paludo, G.R., Dell'Porto, A., Gennari, S.M., McManus, C.M., 2006. Influence of protein supplementation on the resistance and resilience on young hair sheep naturally infected with gastrointestinal nematodes during rainy and dry seasons. Vet. Parasitol. 137, 103-111. https://doi.org/10.1016/j.vetpar.2006.01.004 
Macarthur, F.A., Kahn, L.P., Windon, R.G., 2013. Immune response of twin-bearing Merino ewes when infected with Haemonchus contortus: Effects of fat score and prepartum supplementation. Livest. Sci. 157, 568-576. https://doi.org/10.1016/j.livsci.2013.08.017

Mattioli, M., Barboni, B., Turriani, M., Galeati, G., Zannoni, A., Castellani, G., Berardinelli, P., Scapolo, P.A., 2001. Follicle Activation Involves Vascular Endothelial Growth Factor Production and Increased Blood Vessel Extension 1, BIOLOGY OF REPRODUCTION.

Melado, L., Lawrenz, B., Sibal, J., Abu, E., Coughlan, C., Navarro, A.T., Fatemi, H.M., 2018. Anti-müllerian Hormone During Natural Cycle Presents Significant Intra and Intercycle Variations When Measured With Fully Automated Assay. Front. Endocrinol. (Lausanne). 9, 1-8. https://doi.org/10.3389/fendo.2018.00686

Morotti, F., Zangirolamo, A.F., Silva, N.C., Silva, C.B., Rosa, C.O., Seneda, M.M., 2017. Antral follicle count in cattle: advantages, challenges, and controversy. Anim. Reprod. 14, 514-520. https://doi.org/10.21451/1984-3143AR994

Nguyen, T.P., Frank, A.R., Jewell, J.L., 2017. Amino acid and small GTPase regulation of mTORC1. Cell. Logist. 7, e1378794. https://doi.org/10.1080/21592799.2017.1378794

Ribeiro, E.S., Bisinotto, R.S., Lima, F.S., Greco, L.F., Morrison, A., Kumar, A., Thatcher, W.W., Santos, J.E.P., 2014. Plasma anti-Müllerian hormone in adult dairy cows and associations with fertility. J. Dairy Sci. 97, 6888-6900. https://doi.org/10.3168/jds.2014-7908

Richards, J.A.S., Russell, D.L., Robker, R.L., Dajee, M., Alliston, T.N., 1998. Molecular mechanisms of ovulation and luteinization. Mol. Cell. Endocrinol. 145, 47-54. https://doi.org/10.1016/S0303-7207(98)00168-3

Rico, C., Fabre, S., Médigue, C., Clemente, N. Di, Clément, F., Bontoux, M., Touzé, J.L., Dupont, M., Briant, E., BenoîtRémy, Beckers, J.F., Monniaux, D., 2009. Anti-Müllerian hormone is an endocrine marker of ovarian gonadotropin-responsive follicles and can help to predict superovulatory responses in the cow. Biol. Reprod. 80, 50-59. https://doi.org/10.1095/biolreprod.108.072157

Rodrigues, M., Moreira Silva, L., Manoel Gomes da Silva, C., Alencar Araújo, A., Célia Sousa Nunes-Pinheiro, D., Rondina, D., 2015. Reproductive and metabolic responses in ewes to dietary protein supplement during mating period in dry season of northeast Brazil. Cienc. Anim. Bras. 16, 24-36. https://doi.org/10.1590/1089$6891 \mathrm{v} 16 \mathrm{i} 124613$

Silva, J.R.V., Van Den Hurk, R., De Matos, M.H.T., Dos Santos, R.R., Pessoa, C., De Moraes, M.O., De Figueiredo, J.R., 2004. Influences of FSH and EGF on primordial follicles during in vitro culture of caprine ovarian cortical tissue. Theriogenology 61, 1691-1704. https://doi.org/10.1016/j.theriogenology.2003.09.014

Sohani, A.R., 2018. Identifying blood and bone marrow abnormalities in the laboratory, in: Diagnosis of Blood and Bone Marrow Disorders. Springer International Publishing, pp. 1-15. https://doi.org/10.1007/978-3-319-202792_1

Tan, V.P., Miyamoto, S., 2016. Nutrient-sensing mTORC1: Integration of metabolic and autophagic signals. J. Mol. Cell. Cardiol. 95, 31-41. https://doi.org/10.1016/j.yjmcc.2016.01.005

Tena-Sempere, M., 2012. Deciphering puberty: Novel partners, novel mechanisms. Eur. J. Endocrinol. 167, $733-747$. https://doi.org/10.1530/EJE-12-0669

Van den Brom, R., Moll, L., Kappert, C., Vellema, P., 2015. Haemonchus contortus resistance to monepantel in sheep. Vet. Parasitol. 209, 278-280. https://doi.org/10.1016/j.vetpar.2015.02.026

Visser, J.A., de Jong, F.H., Laven, J.S.E., Themmen, A.P.N., 2006. Anti-Müllerian hormone: A new marker for ovarian function. Reproduction 131, 1-9. https://doi.org/10.1530/ rep.1.00529 
Wagner, M., Yoshihara, M., Douagi, I., Damdimopoulos, A., Panula, S., Petropoulos, S., Lu, H., Pettersson, K., Palm, K., Katayama, S., Hovatta, O., Kere, J., Lanner, F., Damdimopoulou, P., 2020. Single-cell analysis of human ovarian cortex identifies distinct cell populations but no oogonial stem cells. Nat. Commun. 11. https://doi.org/10.1038/s41467-020-14936-3

Weenen, C., Laven, J.S.E., von Bergh, A.R.M., Cranfield, M., Groome, N.P., Visser, J.A., Kramer, P., Fauser, B.C.J.M., Themmen, A.P.N., 2004. Anti-Müllerian hormone expression pattern in the human ovary: Potential implications for initial and cyclic follicle recruitment. Mol. Hum. Reprod. 10, 77-83. https://doi.org/10.1093/molehr/gah015

Zhang, Hua; Liu, K., 2015. Cellular and molecular regulation of the activation of mammalian primordial follicles: somatic cells initiate follicle activation in adulthood. Hum. Reprod. Update 21, 779-786. 


\title{
3. SUPPLEMENTATION OF PROTEIN IN THE DIET OF PERIPUBERTAL INFECTED EWE LAMBS ENABLES THE EXPRESSION OF OVARIAN GENES RELATED TO FOLLICLE ACTIVATION
}

\author{
RESUMO \\ A suplementação de proteína na dieta de ovelhas peripúberes infectadas permite a \\ expressão de genes ovarianos relacionados a ativação folicular
}

\begin{abstract}
O estado nutricional e fisiológico da ovelha peripúbere pode interferir no ambinete ovariano e fertilidade.Os nutrientes após serem absorvidos são transpostados pela circulação sanguínea para todos os tecidos do organismo. A falta ou excesso de alguns nutrientes circulantes atingindo o ovário pode modificar sua expressão gênica. Uma deficiência de proteína no sangue causada pela infecção abomasal com Haemonchus contortus é prejudicial ao desenvolvimento do organismo durante a puberdade. O período peripúbere é uma época de crescimento intenso que requer um nível alto de nutrientes. A ativação do crescimento do folículo ovariano é uma característica essencial controlando o potencial reprodutivo da fêmea. Nós objetivamos determinar se, ao suplementar proteína na dieta de animais infectados, haveria um impacto no ambiente ovariano levando a uma ativação folicular eficiente. Para alcançar este objetivo alimentamos 18 borregas Santa Inês(Ovis aries) - filhas do mesmo reprodutor com um nível de proteína controle(12\%) ou com suplementação de proteína(19\%) e após 35 dias desta dieta, elas foram infectadas artificialmente ou não com 10.000 larvas L3 de Haemonchus contortus. Depois de 42 dias de infecção e 77 dias de dieta, seus ovários esquerdos foram coletados para extração e sequenciamento de RNA. Nós observamos que a suplementação de proteína dietética em animais infectados levou a uma expressão mais alta de genes e processos biológicos ligados a ativação meiótica em folículos pré-ovulatórios e ativação de folículos primordiais, entre outros processos. Os animais suplementados não infectados também apresentaram maior expressão de genes e processos ligados a meiose e outros como comportamento circadiano. As borregas que não foram suplementadas tiveram expressão mais baixa destes mesmos genes e processos, enquanto tiveram maior expressão de processos relacionados a morfogênese tecidual, inflamação e resposta imune. No nosso estudo, a suplementação de proteína na dieta de animais peripúberes infectados permitiu que seus ovários expressassem genes relacionados a um estágio folicular ovariano mais maduro.
\end{abstract}

Palavras-chave: Ovelha púbere, Ovário, Expressão gênica, Proteína dietética, Infecção, Haemonchus contortus 


\title{
ABSTRACT
}

\section{Supplementation of protein in the diet of peripubertal infected ewe lambs enables the expression of ovarian genes related to follicle activation}

\begin{abstract}
The ewe lamb nutritional and physiological state may interfere with the ovarian environment and fertility. Nutrients after being absorbed are transported by circulating blood to all tissues in the body. The lack or excess of circulating nutrients reaching the ovary can change its gene expression. A deficiency of protein in the blood caused by an Haemonchus contortus abomasal infection is detrimental to the organism's development during puberty. The peripubertal period is a time of intensive growth that requires a high level of nutrients. Ovarian follicle growth activation is an essential feature controlling female reproductive potential. We aimed to determine if supplementing protein in infected animals' diet would impact the ovarian environment leading to efficient ovarian follicle activation. To accomplish this aim, we fed 18 Santa Ines ewe lambs (Ovis aries) - bred by the same ram - with either 12\% protein (Control groups) or 19\% protein (Supplemented groups) in their diets. After 35 days of the diet, they were artificially infected or not with 10,000 Haemonchus contortus L3 larvae. Following 77 days of the diet and 42 days of infection, we removed their left ovaries and examined their genes expression through RNA sequencing. We found that protein supplementation in infected animals led to an up-regulation of genes and biological processes linked to meiotic activation in pre-ovulatory follicles and primordial follicle activation, among other processes. The supplemented not infected animals also up-regulated genes and processes linked to meiosis and other processes such as circadian behaviour. The animals that were not supplemented had these same processes down-regulated while they up-regulated processes related to tissue morphogenesis, inflammation and immune response. In our study, diet's protein supplementation of peripubertal infected animals allowed them to express genes related to a more mature ovarian follicle stage.
\end{abstract}

Keywords: Peripubertal Ewe; Ovary; Gene expression; Dietetic Protein; Infection; Haemonchus contortus 


\subsection{INTRODUCTION}

Female reproductive capacity is maintained by the gradual and regular activation of ovarian follicles population. Primordial follicle activation is independent of pituitary hormones and may be influenced by the ovarian environment (Tong et al., 2013). Ovarian follicle development in ruminants is influenced by nutrition through changes in metabolic hormones and direct effects of nutrients in the ovary (Dupont et al., 2014). Changes in gene expression enable the communication between ovarian cells and their environment. The gene MTORC1 senses the ovarian environment's nutritional and physiological states, and its signalling promotes cell growth or autophagy (Guo and Yu, 2019). The induction of MTORC1 activity in oocytes was associated with primordial follicle activation (Tong et al., 2013) and when MTORC1 signalling was super expressed, primordial follicles were activated prematurely (Roa et al., 2009).

Pubertal transition involves a series of morphological, physiological and behavioural changes. During puberty, a surge in luteinising hormone activates meiosis in pre-ovulatory follicles ((Toro et al., 2018)Toro et al., 2018). Meiosis converts diploid germ cells into haploid eggs allowing the egg to be fertilised (Sharma et al., 2018). Environmental changes might also interfere with meiotic resumption and genetic quality of the oocyte, affecting reproductive ability(Hunt and Hassold, 2008).

The abomasal infection with the helminth Haemonchus contortus in sheep causes severe blood losses, anaemia, blood coagulation issues and diminished appetite. These symptoms generate a higher protein requirement to fight the organic imbalance and build an immune response against the parasite. Protein's supplementation to growing sheep during infection resulted in improved immunity against gastrointestinal nematodes (Mcrae et al., 2015). By providing "nutritional therapy" for the animal to balance its homeostasis and combat the parasite, anthelminthic therapy may be avoided. $H$ contortus develops resistance to anthelmintic drugs shortly after being exposed (Jackson et al., 2012). On top of that, these drugs leave residues in sheep milk and dairy products (Imperiale et al., 2004; Tsiboukis et al., 2010) Tsiboukis . Anthelmintic residues in food products may cause embryotoxicity and teratogenicity (McKellar and Scott, 1990) generating a public health concern that demands less usage of these drugs.

There are very few works assessing the effect of protein supplementation in the ovary. One of them is by (Davis et al., 1981)when they found that ovulation rate was increased in mature ewes fed with high protein or energy. However, there is an explicit lack of studies in peripubertal ewe lambs infected with Haemonchus contortus - a widespread counterproductive situation in sheep breeding. We aimed to verify how protein supplementation in the diet of peripubertal ewe lambs with an abomasal nematode infection would affect their ovary gene expression. We examined the ovarian gene expression to evaluate if there was a change caused by different dietary protein levels and infection. This study could model the potential effects of environmental factors nutrition and infection on reproductive health. 


\subsection{METHODOLOGY}

This research project with protocol and procedures employed were ethically reviewed and approved by the Bioethics Commission of University of São Paulo (CENA-USP, protocol number 004/2017), which complies with animal research ethical principles.

\subsubsection{Experimental design, animals and diets}

The 18 Santa Ines ewe lambs we used for this experiment were all half-sisters - bred by the same ram - they were six to seven months old at the beginning of the experimental period. The lambs were divided into four different groups - Control Not Infected, Supplemented Not Infected, Control Infected and Supplemented Infected - being fed a 12\% protein isocaloric diet (Control groups) or a $19 \%$ protein isocaloric diet (Supplemented groups).

The environment they were raised and kept was helminth-free; they were monitored every two weeks for the presence of helminth eggs in their faeces.

The four groups were balanced according to the animals' age and weight to avoid differences in ovarian gene expression due to the peripubertal development period. The average weight and age for each group are detailed in Table 6 . The housing environment was illuminated by natural light during the whole experiment.

The animals were housed in individual pens; the feed was also given twice a day individually, and the water was provided ad libitum. The composition of the diets is defined in Table 7, and their bromatological composition is detailed in Table 8. We followed the general guidelines of the National Research Council (2007) to formulate their diets. The diet's amount was calculated for the lambs' body weight and re-calculated every two weeks observing their current body weight.

After 35 days of consuming this diet, the ewe lambs were either orally infected (Infected groups) or not (Not Infected groups) with 10,000 stage 3 larvae of the nematode Haemonchus contortus. Following 77 days of consuming this diet and 42 days of being infected, they had their left ovaries collected to examine their morphometry through histological analysis. 
Table 6. Average liveweight and age (+/- standard deviation) for each group at the beginning and end of the experiment

\begin{tabular}{|c|c|c|c|c|}
\hline & $\begin{array}{l}\text { Control protein } \\
\text { Not Infected }\end{array}$ & $\begin{array}{r}\text { Control protein } \\
\text { Infected }\end{array}$ & $\begin{array}{r}\text { Supplemented protein } \\
\text { Not infected }\end{array}$ & $\begin{array}{r}\text { Supplemented protein } \\
\text { Infected }\end{array}$ \\
\hline $\begin{array}{l}\text { Mean weigth of the } \\
\text { group at the } \\
\text { beginning of the } \\
\text { experiment }(\mathrm{kg})\end{array}$ & $\begin{array}{r}22.2 \\
(+/-5.5)\end{array}$ & $\begin{array}{r}23.5 \\
(+/-3.9)\end{array}$ & $\begin{array}{r}21.5 \\
(+/-7.2)\end{array}$ & $\begin{array}{r}22.1 \\
(+/-5.6)\end{array}$ \\
\hline $\begin{array}{l}\text { Mean weigth of the } \\
\text { group at the end of } \\
\text { the experiment }(\mathrm{kg})\end{array}$ & $\begin{array}{r}29.5 \\
(+/-4.2)\end{array}$ & $\begin{array}{r}31.7 \\
(+/-4.4)\end{array}$ & $\begin{array}{r}28.1 \\
(+/-11.4)\end{array}$ & $\begin{array}{r}29.1 \\
(+/-6.4)\end{array}$ \\
\hline $\begin{array}{l}\text { Mean group's age at } \\
\text { the start of } \\
\text { experiment(days) }\end{array}$ & $\begin{array}{r}220 \\
(+/-5.4)\end{array}$ & $\begin{array}{r}217 \\
(+/-9.6)\end{array}$ & $\begin{array}{r}215 \\
(+/-5.9)\end{array}$ & $\begin{array}{r}208 \\
(+/-7.7)\end{array}$ \\
\hline $\begin{array}{l}\text { Mean age of the } \\
\text { group(days) at the } \\
\text { end of the } \\
\text { experiment }\end{array}$ & $\begin{array}{r}299 \\
(+/-5.4)\end{array}$ & $\begin{array}{r}296 \\
(+/-9.6)\end{array}$ & $\begin{array}{r}294 \\
(+/-5.9)\end{array}$ & $\begin{array}{r}287 \\
(+/-7.7)\end{array}$ \\
\hline
\end{tabular}

Table 7. Composition of the control protein and supplemented protein diets

\section{Forage feed}

Tifton-85 hay

$60 \%$

$60 \%$

Concentrated feed

Ground corn

Soybean meal

\section{Crude protein}

(\% total diet) 


\subsubsection{Bromatological analysis of the diet}

We calculated dry matter in the diet after dried out in an electric kiln (Odontobrás 1.6, Brazil) at $105^{\circ} \mathrm{C}$ for 24 hours. Mineral matter's calculation was calculated after burning the diet sample out in a muffle furnace (JUNG, Brazil) at $550^{\circ} \mathrm{C}$ for five hours and 30 minutes. Crude protein's amount was established with a micro-Kjeldahl method of vapour distillation (Tecnal, Brazil) using $15 \mathrm{ml}$ of sodium hydroxide with volatilised nitrogen $(\mathrm{NaOH} 12 \mathrm{~N})$ collected in the boric acid solution at 2\%(H3BO3) and quantified by titration with a sulfuric acid solution ( $\mathrm{H} 2 \mathrm{SO} 40.005 \mathrm{~N}$ ) with multiplication by conversion factor 6,25 . The ethereal extract was quantified with petroleum ether by heating it in a fat extractor (Soxhlet- TE-044-8/50 - Tecnal, Brazil). The quantification of fibre in neutral detergent was obtained after washing the diet samples in fibre quantification bags Ankom F57 (Ankom Technology Corp., USA) at $90^{\circ} \mathrm{C}$ for 1 hour in neutral detergent solution (Van Soest et al., 1991). Then alphaamylase and sodium sulfite were added (TE-149 - Tecnal, Brazil) followed by two washes with distilled water plus alpha-amylase at $90^{\circ} \mathrm{C}$ for five minutes and another acetone wash for five minutes. These bags were put in the electric kiln at $105^{\circ} \mathrm{C}$ (Odontobrás, Brazil) during four hours and then in a dryer. They were weighed in an analytical balance (UY220, Japan) and transferred to porcelain crucibles incinerated in a muffle furnace (JUNG, Brasil) at $530^{\circ} \mathrm{C}$ for 3 hours and 30 minutes. The fibre's in neutral detergent calculation (FDN) was performed after correction for ashes. The fibre in acid detergent (FDA) was estimated after the diet samples were washed with an acid detergent solution at $90^{\circ} \mathrm{C}$ for 60 minutes followed by four rinses in distilled water at $90^{\circ} \mathrm{C}$ for five minutes and another five minutes wash with acetone. The bags with diet samples were put in an electric kiln at $105^{\circ} \mathrm{C}$ for four hours, then in a dryer until reaching $25^{\circ} \mathrm{C}$ for their weighing. The lignin was predicted using the FDA bags; both were calculated after being corrected for ashes. After the bags were weighted, were put in a sulfuric acid solution at $72 \%$ during three hours. They were rinsed with distilled water at $90^{\circ} \mathrm{C}$ for five minutes and washed with acetone for another five minutes. Bags with diet were put in an electric kiln at $105^{\circ} \mathrm{C}$ for four hours, then were weighed and put in porcelain crucibles to burn out in a muffle furnace at $530^{\circ} \mathrm{C}$ for three hours and 30 minutes. The quantification of energy in the diet ingredients was done in the calorimeter bomb 6200(Parr Instrument Company - USA) after the combustion. 
Table 8. Bromatological composition $\left(\mathrm{g} \mathrm{kg}^{-1}\right.$ of dry matter at $\left.100^{\circ} \mathrm{C}\right)$ and energy $(\mathrm{MJ})$ of the diets' ingredients

\begin{tabular}{llll}
\hline & $\begin{array}{l}\text { Concentrated } \\
\text { feed } \\
\text { Supplemented } \\
\text { Protein }\end{array}$ & $\begin{array}{l}\text { Concentrated } \\
\text { feed Control } \\
\text { protein }\end{array}$ & $\begin{array}{l}\text { Tifton-85 } \\
\text { Hay }\end{array}$ \\
& 897.11 & 896.50 & 877.90 \\
\hline Dry matter at $\mathbf{1 0 5}^{\circ} \mathbf{C}$ & 317.69 & 153.04 & 104.20 \\
Crude Protein & 0.018 & 0.018 & 0.019 \\
Energy & 246.26 & 168.34 & 727.90 \\
Fiber in neutral detergent & 188.75 & 131.89 & 386.80 \\
Fiber in acid detergent & 14.88 & 23.19 & 20.70 \\
Ethereal extract & 99.60 & 84.63 & 66.87 \\
Mineral matter & 26.93 & 25.75 & \\
Lignin & 10.21 & 8.39 & \\
Phosphorus & & & \\
\hline
\end{tabular}

\subsubsection{Absence of oestrus synchronisation in the ewe lambs}

To ensure our objective of studying the effects of diet's protein supplementation in the infected animals ovarian's gene expression., we opted for not synchronising the ewe lambs' oestrus. Hormonal therapy to synchronise the oestrus would affect ovarian gene expression becoming a confounding factor in our study.

\subsubsection{Blood collection, complete blood count and blood biochemical} analysis

We collected five $\mathrm{mL}$ of blood from the animals' jugular vein before being fed in the morning. The blood was collected in Vacutainer tubes with or without EDTA.

The blood samples in EDTA were analysed in the automatic analyser Davol Poch-100iV Diff immediately after their collection. Blood samples were collected from the animals on four different dates. We analysed hematocrit, number of red blood cells (RBC), number of white blood cells (WBC), haemoglobin (HGB), mean corpuscular haemoglobin $(\mathrm{MCH})$, number of platelets, mean corpuscular volume (MCV) and mean corpuscular haemoglobin concentration (MCHC).

The samples which did not contain EDTA were centrifuged for 15 minutes at $1310 \mathrm{~g}$ at $4^{\circ} \mathrm{C}$ to obtain blood serum which was aliquoted and kept in storage at $-20^{\circ} \mathrm{C}$ until the biochemical analysis 
was performed. The plasma albumin levels, glucose, urea and total protein were measured with Labtest kits (Labtest Diagnostica S.A.- Brazil) following the manufacturer instructions and its reading performed by spectrophotometer (Perkin Eusing Elmer - Lambda EZ150 UV/Vis Spectrophotometer).

\subsubsection{White blood cell counts}

Counting and differentiation of the white blood cells were done through blood smears of each animal on the four dates. We counted the first visualised 100 cells in the microscope at a $100 \mathrm{X}$ magnification of a Nikon Eclipse E200 microscope (Sohani, 2018).

\subsubsection{Faecal egg count}

Infection's level was examined every fourteen days by faecal egg count of each individual. We sampled faeces directly from the ewe lambs' rectum, and the eggs present were counted in a McMaster chamber under the Nikon Eclipse E200 microscope according to the methodology by (Coles et al., 1992).

\subsubsection{Beta-hydroxybutyrate concentration}

Beta-hydroxybutyrate's concentration was measured in four different dates throughout the experiment. We assessed its concentration with Freestyle Optium Beta-Ketone test (Abbot) in whole blood just after its collection. On the first date, the lambs had been on a supplemented or control protein diets for one month but had not been infected yet. The three subsequent measurements were done after the artificial oral infection with the 10,000 Haemonchus contortus L3 stage larvae.

\subsubsection{Statistical Analyses of faecal egg counts, beta-hydroxybutyrate levels, blood cell and biochemical parameters}

We used standardised parameters' values for the following statistical analyses. We subtracted the individual values out of the group's mean and divided by the standard deviation value. Shapiro-Wilks analysis was performed on all the measurements of the data to ensure their normality.

We also performed Pearson correlation analysis in the plasma parameters (plasma protein, albumin, haemoglobin and glucose), whole blood beta-hydroxybutyrate, serum AMH and number of red blood cells to ensure a non-linearity relationship between them.

We used factorial ANOVA to assess the variation due to the interaction of protein level in the diet (Diet: Supplemented versus Control) and infection status (Infection: Infected versus Not 
Infected). We also performed ANOVA repeated measures to evaluate the effect over time in the four different data collections.

We analysed covariance between the measured parameters following a pattern where the protein level on the diet (Supplemented or Control) and Infection status (Infected or Not Infected) were categorical factors; the plasma variables were the dependent variables and AMH the continuous predictor. We also performed covariation analysis to examine a possible influence of AMH on several physiological factors and primordial follicle and oocyte sizes. The analyses above were performed in the software STATISTICA (StatSoft - version 12).

\subsubsection{Ovary RNA extraction}

Just after the left ovary was removed through ovariectomy, it was snap frozen in liquid nitrogen and kept in a $-80^{\circ} \mathrm{C}$ freezer until RNA extraction was performed. Total RNA was extracted from a fragment of the left ovary using Trizol reagent (ThermoFisher, Waltham, Massachusetts, USA). In brief, the frozen ovarian fragments were macerated with a pestle and mortar in liquid nitrogen until they were pulverized. Quickly after that, Trizol reagent was poured over, and the sample was again macerated. The tissue lysate was then centrifuged and incubated subsequentially with chloroform and 2-propanol. The RNA pellet, formed after the 2-propanol incubation, was washed twice with ethanol $75 \%$ and re-suspended in RNAse free water.

\subsubsection{RNA quality control}

RNA Samples were verified for their purity and concentration through absorbance analysis of their 260/280 and 260/230 ratios in a spectrophotometer (NanoDrop 2000, Wilmington, DE)(Table 9). To determine its integrity, we analysed 500ng of each RNA sample in an agarose gel (Figure 13). Some samples were not analysed in the agarose gel because there was not enough RNA for the gel and sequencing. The RNA samples were further analysed through Agilent 2100 Bioanalyser at Novogene (San Diego-CA-USA) for more precise quantification and integrity determination (Figure 14). 
Table 9: List of ovarian RNA samples, their concentration, 260/280 and 260/230 absorbance ratios

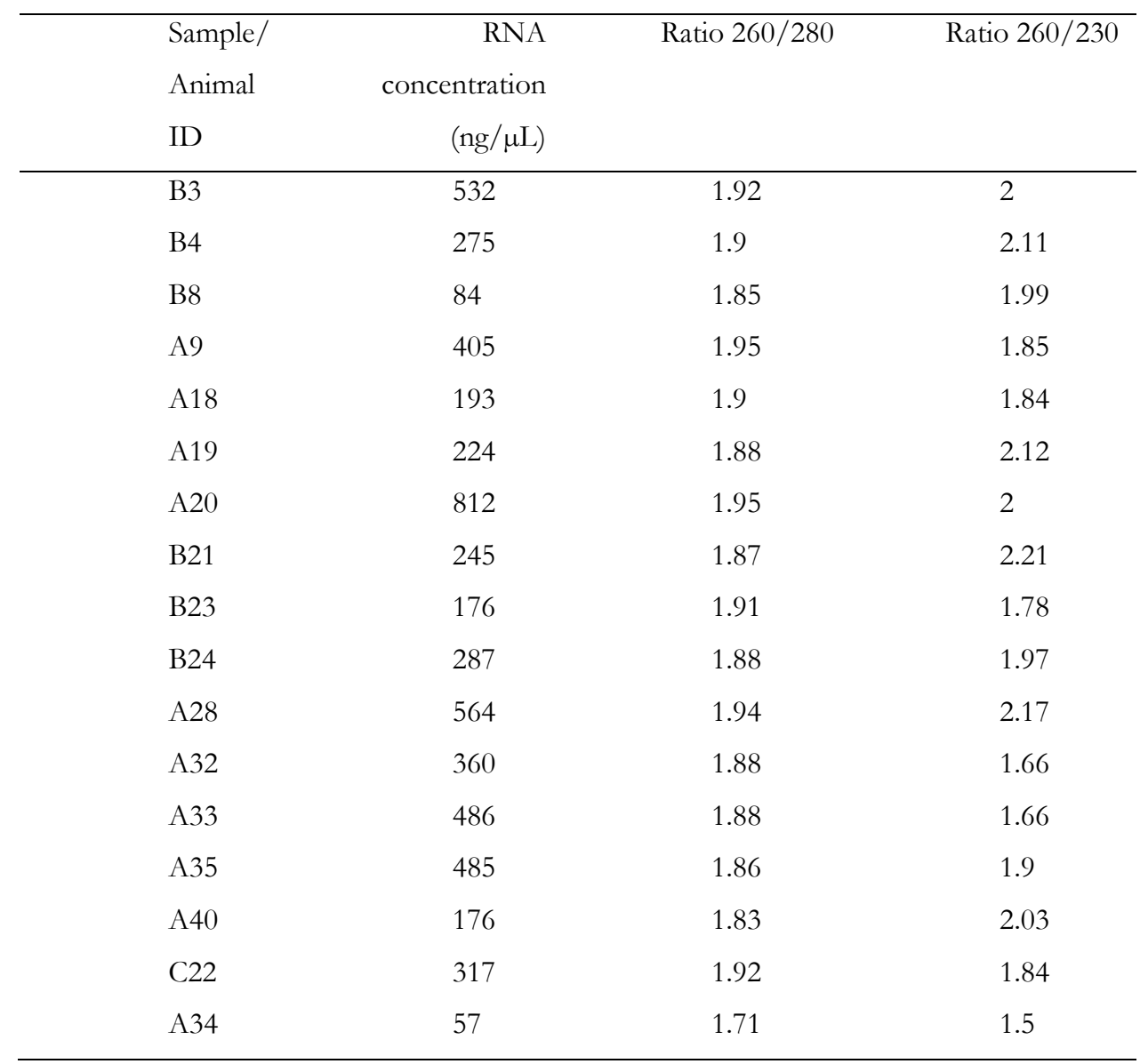

\section{B3 A34 C0 B9 A4 B19 B22 A23 B20 A24 B28 A21 B32 A35 B35 B40}

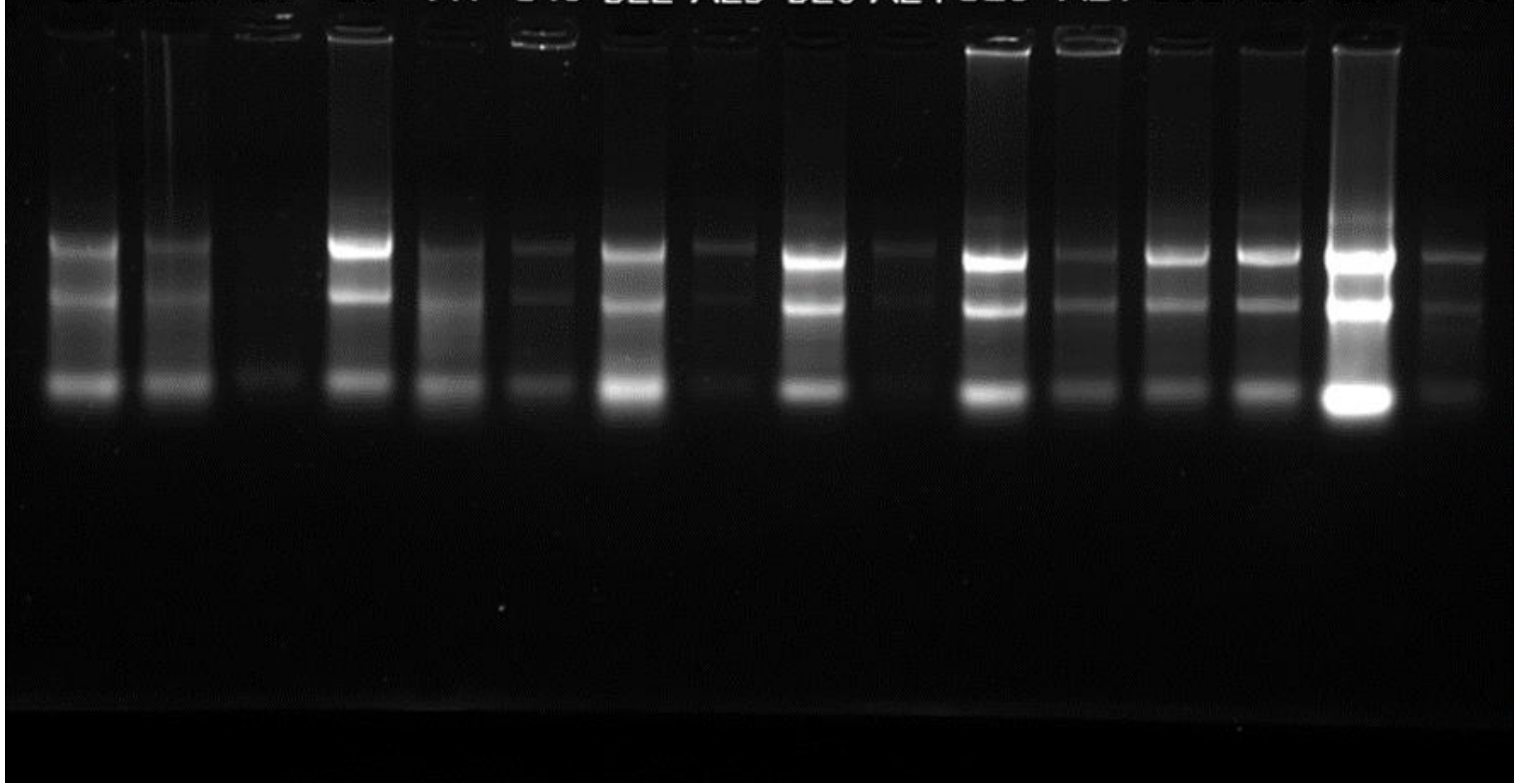

Figure 13: Gel electrophoresis with ovarian RNA samples with the correspondent animal identification 


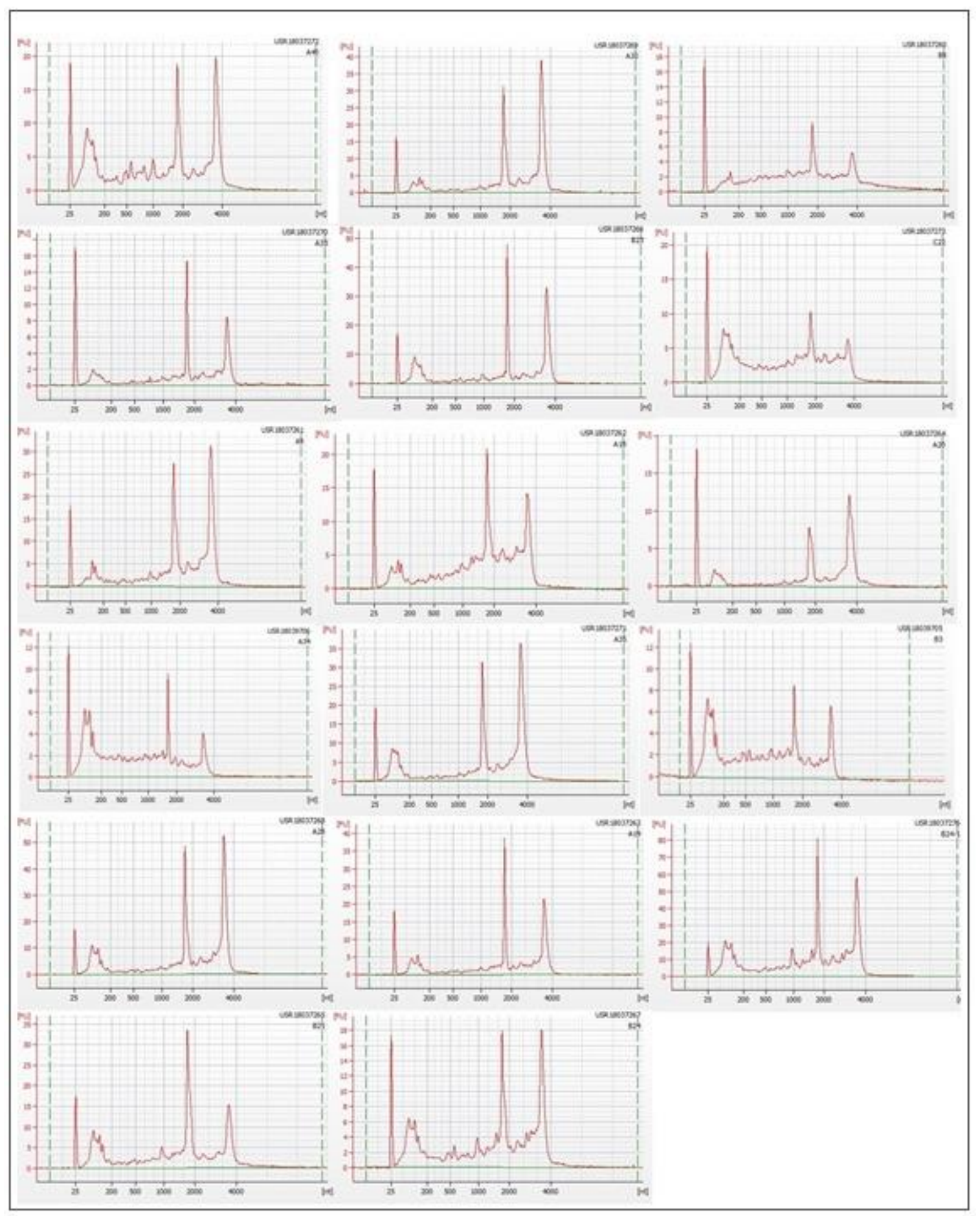

Figure 14: Bioanalyser images of RNA samples 


\subsubsection{1. cDNA's Library elaboration}

After the RNA quality control analysis, the RNA was enriched using beads oligo-DT, these beads attach to the poly-A tail of the messenger RNAs to specifically select them. Firstly, the messenger RNA was randomly fragmented with the addition of the fragmentation buffer. The cDNA was then synthesized using the messenger RNA as a template and random hexamer primers as building blocks. After this, a buffer specific for the second strand synthesis plus dNTPs, RNase H and DNA polymerase one were added to initiate the second strand synthesis. At the end of this stage, the terminations were repaired, linking A, linking the adaptor for sequencing, and completing the cDNA library through size selection and PCR enrichment. The cDNA library passed three quality controls: a preliminary concentration measurement with Qubit, a test to measure the insert size, and a quantitative PCR to assess the library size effectively.

\subsubsection{Library Sequencing}

The qualified libraries were put into the Illumina Hiseq 2000(Illumina- San Diego- USA) sequencer after being grouped according to their effective concentration and expected data volume. The RNA sample of the ewe lamb 1715 did not have enough RNA to perform sequencing.

\subsubsection{RNA sequencing data analysis}

The reads generated by RNA sequencing were analysed using the software CLC Genomics Workbench v 12.02 (QIAGEN, Aarhus, Denmark) after the sequencing reads were imported to the software environment.

\subsubsection{Import of the sequencing reads}

The sequencing reads were imported to the software using the section "Illumina High Throughput Sequencing Import". Inside this section, the selected options were "paired reads; discard reads names; paired-end(forward-reverse); minimum distance 1, maximum distance 1000; remove failed reads". The distance measurement used includes the complete read's sequence, what in the case of paired-end libraries, the measured distance goes from the beginning of the forward read to the beginning of the reverse read.

\subsubsection{Reads mapping and reference genome}

The option used for the mapping step were: "Genome annotated with transcripts", where the RNA splicing is taken into consideration. The annotations linked to the RNA transcripts were used to define how the transcripts were amended. In this option, RPKM and TPM's expression values were 
calculated based on the length of the transcripts supplied by the mRNA tracks. It was allowed two mismatches maximum, and in the counting scheme, the broken pairs were included - in which a pair of sequences is counted as two, and a single sequence is counted as one.

We mapped the sequenced reads to the sheep (Ovis aries) reference genome version Oar_rambouillet v. 1.0 (2017). The reference genome was imported to the software CLC Genomics Workbench v 12.02 (QIAGEN, Aarhus, Denmark) through its "Import Tracks" tool. The reference genome had been previously downloaded from NCBI ( National Center for Biotechnology Information) database (https://www.ncbi.nlm.nih.gov/genome/?term=Ovis+aries - Genbank assembly). The genomes' reference sequence was obtained in separated FASTA format files and the genome annotations through only one GFF/GFF3 combined file. The sequencing reads' chromosomes were named in the same way as the reference genome for the adequate files' association.

\subsubsection{Normalisation of RNA sequencing data}

The normalisation was necessary because the sequencing depth differed among samples; therefore, they were compared without bias. The difference of depth consists of a difference of size for each sample's RNA sequencing library. The normalisation method used was the weighted trimmed mean of the $\log$ expression ratios (trimmed mean of M values-TMM) by Robinson and Oshlack,(2010). This method adjusts the library sizes based on the assumption that most genes are not differentially expressed.

\subsubsection{RNA sequencing analysis}

In short, the RNAseq analysis was done according to the following steps. The annotated RNA transcripts were imported to the software environment using the tool RNAm track. The reads were mapped using the complete genome and transcripts. After this mapping, the reads were categorised and assigned to the transcripts using the estimation algorithm EM (intrinsic to the CLC Genomics Workbench software; its functioning is explained in the following section). The gene counts were obtained by adding over the (EM-distributed) transcript counts. The option chosen to measure the expression level was "Count paired reads as two" to ensure that each read of the pair is counted to the gene's expression to which the read overlaps. If a sequence was paired to multiple distinct places, but less than the maximum number of hits established, this sequence was randomly assigned to one of these places. The EM algorithm did this random distribution.

\subsubsection{EM estimation algorithm}

The EM algorithm was inspired by the RSEM(Li and Dewey, 2014) and eXpress (https://pachterlab.github.io/eXpress/manual.html) methods. It successively estimates the abundance of genes/transcripts according to these abundances. For a gene with two transcripts, where one of the 
transcripts is twice longer than the other turns the longer transcript twice more abundant, which means that two of these three reads originate from the longer transcript. The final read comes from the shorter transcript in the exon common to both transcripts. The longer transcript has a second exon which also generates two reads. So, the longer transcript is twice more abundant, and because it is twice longer, it generates four times the number of reads. If the shorter transcript were twice more abundant than the longer transcript, there would be equal numbers of reads of each transcript.

A mapping is a set of transcripts to which one read can map. A maximization expectancy procedure estimated the transcript abundance. In the cases mentioned on the previous paragraph, some reads had the mapping $\mathrm{a} 1=\mathrm{ft} 1 ; \mathrm{t} 2 \mathrm{~g}$ (these are reads mapped in a $\mathrm{y}$ non-unique way), and some reads had the mapping $\mathrm{a} 2=\mathrm{ft} 2 \mathrm{~g}$ (these are reads mapped uniquely). On both examples, the mapping counting a1 is three because three reads are shared between the transcripts. The mapping counting a2 is two in the first example and one in the second example.

1.When the process starts, the transcripts abundances are evenly distributed under the assumption that all the transcripts are equally expressed.

2. Expectancy step: the transcript assumed abundances were used to calculate each transcript's expected counting, meaning the expected number of reads that should be assigned to a given transcript. This process was done passing over all the mappings that include a given transcript and assigning a proportion of the total counting of that mapping to the transcript. The proportion corresponds to the proportion of total abundance of transcripts in the mapping due to the target.

3. Maximisation step: the countings assigned to each transcript were used to re-compute the transcript abundance. This step was done passing over all the targets. Each target divides the proportion of countings currently assigned to the transcript (=total countings per transcript divided by the total number of reads) by the target's length. It is expected that longer transcripts proportionately generate more reads.

4. Repetition of step 2 until convergence: once the algorithm converged, each mapped read in a non-unique way is randomly assigned to a transcript according to the same mapping's transcript abundances. The column of total reads of transcripts shows these assignments. The values of RPKM and TPM are assigned to each transcript.

\subsubsection{Differential expression analysis of the RNA sequencing data}

The tool we used for the differential expression analysis of the RNA sequencing data performs a statistical test of differential expression for the set of expression tracks with associated metadata using multifactorial statistic based in a negative binomial model of the generalised linear model (GLM). 
We used the RNA's sequencing tracks that measured expression at the gene level (GE tracks). The metadata associated was each track sample assignment to its belonging group Control Not Infected, Supplemented Not Infected, Control Infected or Supplemented Infected. For comparison between groups, the "ANOVA all group pairs" was chosen to test the differences between all the groups in one factor. We also used "age" as a controlling factor because, in the peripubertal developmental stage, a difference between the animals' ages could cause differences in the gene expression.

Once we had the lists of genes differentially expressed identified (FDR p-value $<$ or $=$ to 0.05), we searched on several databases to find out their function and in which biological processes they were found to be involved. We used the following databases for this search: Kyoto Encyclopedia of Genes and Genomes (KEGG) PATHWAY, Gene Ontology (GO) Project at Mouse Genome International (MGI), Molecular Signature Databases v7.0 (MSigDB), Database of Phenotypes and Genotypes at the National Centre of Biotechnology Information (dbGap-NCBI), Genome-Wide Association Studies catalogue (GWAS - National Human Genome Research Institute), Hallmark Gene Sets, Reactome Gene Sets and GeneCards - The Human Database.

\subsubsection{Analysis of differentially expressed gene lists to identify enriched pathways shared or selectively enriched between groups.}

This analysis was done with the software Metascape (Zhou et al., 2019). It combined searching for functional gene enrichment, protein-protein interaction analysis, gene annotation and membership using 40 independent databases. Also, a comparative analysis of datasets through orthogonal experiments was performed. The comparison among these datasets allowed identifying pathways/networks coherently and detected accurate signals above the experimental noise (Bushman et al., 2009).

The protocol followed was the same for all the comparisons between gene lists. In the item “Annotation", we selected the databases: Gene Symbol, Description, Biological process, Database of Genotypes and Phenotypes (dbGap-NCBI), GWAS, Variations, Kegg Pathways and Hallmark gene sets. In the item "Membership" the selected databases for the analysis were: Reactome Gene Sets, Kegg Pathways, GO Biological process. In the item "Enrichment”, Kegg Pathways, Hallmark Gene Sets, GO Biological Process, and Reactome Gene Sets were selected. For the enrichment of pathways and biological processes the parameters used were: Minimum Overlap 3, p-value cutoff 0.01, Minimum Enrichment 1.5 and for the enrichment of protein-protein interaction we used the parameters: Minimum network size 3, Maximum network size 500 using the databases Biogrid, InWeb and OmniPath.

\subsubsection{Enrichment clustering}


The whole genome was used as the enrichment background. Terms that had a p-value smaller than 0.01, a minimum count of three, and an enrichment factor larger than 1.5 were selected and grouped into clusters based upon their membership affinity. P-values were calculated utilising Benjamini-Hochberg method to account for multiple testing (Benjamini and Hochberg, 1995). Each term within a cluster that was most significant was chosen to represent a given cluster.

During the data post-processing, the Kappa similarities between all the enriched pairs of terms were computed and used to join the terms hierarchically in a tree. They were fused in sub-trees of similar term groups. By absorbing most redundancies in representative groups, the enrichment clustering avoided confounding problems in data interpretation, which may arise when multiple ontologies are reported. However, the bar graph did not capture similarities and redundancies between the clusters. The enrichment network visualisation approach represents each enriched term with a node. These nodes are connected between pairs if their Kappa similarities were above 0.3, producing a network portrayed using Cytoscape (Shannon et al., 2003). Redundant terms inside a cluster conducted to the formation of local complexes well-adjusted due to their high similarities intra-cluster. Clusters were occasionally linked to similar terms reflecting the relationship of two separate processes.

\subsubsection{Analysis of protein networks}

Because analysing gene lists in the context of proteins interactions may help to enlighten complex biochemical processes or components of signals' translation that rule biological processes, we used an algorithm of complex identification built in Metascape. The MCODE algorithm infers results that are easier to interpret in a biological context. It extracts protein complexes that are built-in the more extensive network. A functional enrichment is also performed to combine the three ontological more significant terms to annotate the possible biological roles for each MCODE complex.

The protein pathways provide a complementary way to identify dynamically, the groups of protein that are probably functionally relevant. The connected proteins inside a PPI (protein-protein interaction) network are probable collaborators, forming a translation signal of a pathway or molecular complex that execute related biological processes. The genes that do not interact with other hits are filtered to generate a sub-list with a better ratio between the signal to noise.

The processes and pathways described in the enrichment analysis were automatically applied to the proteins network, and the more enriched terms characterise their biological significance.

The algorithm Molecular Complex Detection (MCODE) was applied to identify regions with pathways densely connected. Each component of the region was more probably associated with a functional unity or a complex than the rest of the network. The enrichment analysis of the pathways/biological processes was automatically applied to the proteins in the network to understand the role of each of the identified MCODE components (minimum size of three proteins), and the more enriched terms characterised their biological significance. 


\subsubsection{Statistical methodology used in the Enrichment analysis}

Considering $N$ as the total number of genes (the whole genome as background), the number of genes in a pathway as $k$ and, our input gene list containing $M$ genes, among which $n$ genes are found in the same $k$ given pathway.

The enrichment factor shows how many folds more individual pathway members were found in our input gene list in comparison to what would have been anticipated randomly:

$$
\text { Enrichment Factor: } \quad n M k N=n N k M
$$

If our $M$ input genes were selected by chance out of the pool of $N$ genes, the probability that we obtained $n$ genes from the given $k$ pathway would be:

$$
(k n)(N-k M-n)
$$

This expression above is known as hypergeometric distribution. The p-value(log10p) was defined as the probability to obtain $n$ or more pathway members, creating an accumulative hypergeometric distribution:

$$
\mathrm{p}=\Sigma \mathrm{i}=\operatorname{nmin}(M, K)(\text { in })(N-k \cdot M-\imath)
$$

A more negative p-value indicated that the observed enrichment was less due to randomness (Zar, 1988). The software used the BH-adjustment (Benjamini and Hochberg, 1995) to address the statistical problem of multiple testing, the Q number of pathways and finding significative $\mathrm{p}$-values only due to the large number of the pathways queried against. For the $\mathrm{BH}$-adjustment to be calculated, all $\mathrm{p}$ values were firstly classified from small to large. If a $\mathrm{p}$-value ranked $\mathrm{i}$, it would be expected that $\mathrm{pQ}$ pathways would be found with an equal or better $\mathrm{p}$-value at random under the Bonferroni correction. Because only i pathways were observed, part of our observations would be false (false discovery rate FDR).

$$
\min (\mathrm{pQi}, 1)
$$

The $z$ - score is the Z- standard deviation away from the anticipated counts(Kim and Volsky, 2005). Although it is just an approximate form, its formula is as follows:

$$
\mathrm{Z}=(\mathrm{n}-\mathrm{MkN}) \sigma
$$




\subsubsection{RT-qPCR to validate gene expression}

To confirm the difference in gene expression found in the RNA sequencing analysis between groups Supplemented not Infected vs Control not Infected and between the groups Supplemented Infected vs Control Infected, we performed RT-qPCR for the genes INHBA, HSD17B1, FST, C7, RABEP1 and KDM5B. The mRNA sequences used were obtained on the NCBI website (https://www.ncbi.nlm.nih.gov/nuccore/).To design the primers, we used the tool Primer 3 plus(https://primer3plus.com/cgi-bin/dev/primer3plus.cgi). The primer pairs' quality was assessed with the tool NetPrimer(http://www.premierbiosoft.com/NetPrimer/AnalyzePrimerServlet), and the best-rated pair was chosen (Table 10). The primers specificity was verified by running the PCR product in gel electrophoresis and melting curve analysis. According to section $\mathrm{X}$, the RNA extraction was performed, and it was quantified with Nanodrop 2000(Wilmington-USA). The RNA samples were treated with DNAse enzyme (Promega-Madison-USA), and then the reverse transcription reaction was performed to obtain cDNA. The reactions were performed according to the kit GoTaq- 2-Step RTqPCR System (Promega-Madison-USA).

Total RNA - $1200 \mathrm{ng}$ of each sample - were incubated with random primers at $70^{\circ} \mathrm{C}$ for 5 minutes and then at $4^{\circ} \mathrm{C}$ for 5 minutes. After that, it was mixed with GoScript $5 \mathrm{X}$ Reaction Buffer, MgCl2 25mM, PCR Nucleotide Mix - 10mM, Recombinant RNasin Ribonuclease Inhibitor and GoScript Reverse Transcriptase enzyme. The cycles for the reverse transcriptase reaction were annealing at $25^{\circ} \mathrm{C}$ for 5 minutes, extension at $42^{\circ} \mathrm{C}$ for 60 minutes and inactivation at $70^{\circ} \mathrm{C}$. After this, the samples were stored at $-80^{\circ} \mathrm{C}$ until the qPCR reactions were performed. We used 15 nanograms of cDNA in 3 microlitres for each qPCR reaction, and each sample was performed in triplicate. The primers for each gene were used in the concentration of $900 \mathrm{nmol}$. The qPCR reactions followed the cycle: $1 \times 95^{\circ} \mathrm{C}$ for 5 minutes, 50 cycles of: hold at $95^{\circ} \mathrm{C}$ for 10 seconds, hold at [primer annealing temperature] for 25 seconds and hold at $72^{\circ} \mathrm{C}$ for 25 seconds. The melting curve was done with a ramp from [primer annealing temperature] to $95^{\circ} \mathrm{C}$, with a 90 seconds hold on the first step and a 4 seconds hold on the next steps. These reactions were performed on the qPCR thermocycler Rotor-Gene Q 5plex HRM Platform (Qiagen-Denmark). PCR efficiencies were obtained with the LinRegPCR software(Ruijter et al., 2009). The normalized Ct levels for the target genes were obtained from the subtraction of the Ct of the target gene out of the reference gene RPL7A (ribosomal protein L7a). The reference gene was chosen out of the RNA sequencing analysis data. Its choice was based on an analysis selecting the genes most highly expressed in all samples and the ones with the smallest variation (ANOVA) among samples.

Table 10. Sequence, annealing temperature and product size of primers used for $\mathrm{qPCR} . * \mathrm{~F}=$ forward primer; $\mathrm{R}=$ reverse primer; product size in base pairs 


\begin{tabular}{|c|c|c|c|c|c|}
\hline $\begin{array}{l}\text { Gene } \\
\text { symbol }\end{array}$ & $\begin{array}{l}\text { Accession } \\
\text { no. }\end{array}$ & Species & Primer sequence 5' - 3' & $\begin{array}{l}\text { Annealing } \\
\text { temperature } \\
\left({ }^{\circ} \mathrm{C}\right) \\
\end{array}$ & $\begin{array}{l}\text { Product } \\
\text { size(bp) }\end{array}$ \\
\hline \multirow[t]{2}{*}{ INHBA } & $\begin{array}{l}\text { NM_001009 } \\
458.1\end{array}$ & $\begin{array}{l}\text { Sheep(Ovis } \\
\text { aries) }\end{array}$ & F: GGACGGAGGGCAGAAATGAA & 63.7 & 80 \\
\hline & & & R:TTCCTGGCTGTGCCTGATTC & & \\
\hline \multirow[t]{2}{*}{ HSD17B1 } & $\begin{array}{l}\text { XM_027974 } \\
501.1\end{array}$ & $\begin{array}{l}\text { Sheep(Ovis } \\
\text { aries) }\end{array}$ & F: CTTCTACCGCTACTGTCGCC & 60 & 82 \\
\hline & & & R:GAGGAAGACCTCGACCACCT & & \\
\hline \multirow[t]{2}{*}{$\mathrm{C} 7$} & $\begin{array}{l}\text { XM_004017 } \\
017.4\end{array}$ & $\begin{array}{l}\text { Sheep(Ovis } \\
\text { aries) }\end{array}$ & F:TGCCTAAATGTCAGCCCTGG & 62.6 & 84 \\
\hline & & & R:CATGCAAGGAGGACCCACAT & & \\
\hline \multirow[t]{2}{*}{ FST } & $\begin{array}{l}\text { XM_012096 } \\
672.3\end{array}$ & $\begin{array}{l}\text { Sheep(Ovis } \\
\text { aries) }\end{array}$ & F:GGATCTTGCAACTCCATTTCG & 61.9 & 119 \\
\hline & & & R:AACACTGAACATTGGTGGAGG & & \\
\hline \multirow[t]{2}{*}{ RABEP1 } & $\begin{array}{l}\text { XM_015098 } \\
590.2\end{array}$ & $\begin{array}{l}\text { Sheep(Ovis } \\
\text { aries) }\end{array}$ & $\begin{array}{l}\text { F:GCTCAGTTATCAAATGAGGAGG } \\
\text { AAC }\end{array}$ & 61.3 & 87 \\
\hline & & & R:CCCGGATGGCAACAGTAAGT & & \\
\hline \multirow[t]{2}{*}{ KDM5B } & $\begin{array}{l}\text { XM_027976 } \\
024.1\end{array}$ & $\begin{array}{l}\text { Sheep(Ovis } \\
\text { aries) }\end{array}$ & F:CTGCACTGTTGATTGGCTGC & 63 & 98 \\
\hline & & & R:TGCAGATCATCTCGTCGTGG & & \\
\hline \multirow[t]{2}{*}{ RPL7A } & $\begin{array}{l}\text { XM_027966 } \\
154.1\end{array}$ & $\begin{array}{l}\text { Sheep(Ovis } \\
\text { aries) }\end{array}$ & F:CAGCCTTTCAAGATGCCGAAG & 62.5 & 113 \\
\hline & & & R:TTCTCGAACAGGGGGTTGAC & & \\
\hline
\end{tabular}

\subsection{Results}

\subsubsection{Haematological and biochemical parameters}

At the end of the experiment, we found a positive correlation among the number of red blood cells, haemoglobin and haematocrit. Haematocrit and haemoglobin values were positively correlated (0.96), so we chose using only haemoglobin in the primordial follicle and oocyte size statistical analysis to avoid redundancy and statistical power loss. Plasma protein and infection influenced haemoglobin levels as found in the covariance analysis for haemoglobin as the dependent variable, diet and infection as categorical factors and plasma protein as a continuous predictor.

There was significant variation in plasma protein on the fourth date between Control and Supplemented protein diet groups on factorial ANOVA, supplemented groups presented higher levels $(\mathrm{p}=0.021)$. Levels of plasma albumin did not vary significantly according to time, diet or infection. Glucose plasma concentration varied from 40.3 to $73.3 \mathrm{mg} / \mathrm{dL}$ on three collection dates but also did not vary significantly with diet or infection status or with time. Glucose concentration remained inside the typical values for the species (Braun et al., 2010). There was significant variation for plasma urea levels between different diets, infection status and interaction diet vs infection on the fourth date (respectively $\mathrm{p}=0.000, \mathrm{p}=0.020, \mathrm{p}=0.026$ ). 
Haemoglobin levels varied significantly according to time after the infection $(p=0.05)$ between infected and not infected animals. The not infected animals presented higher levels of haemoglobin on the three pos infection dates. Haemoglobin also varied significantly on the fourth date when infection status was considered $(\mathrm{p}=0.005)$.

Red blood cells' number varied significantly according to infection status on the third and fourth dates $(\mathrm{p}=0.032$ and $\mathrm{p}=0.00026)$. In counting white blood cells, the number of monocytes varied significantly with the interaction diet vs infection on the second date, being higher in the Control infected group $(\mathrm{p}=0.036)$. The neutrophils' number varied according to the diet on the fourth date, and it was significantly higher in the supplemented protein groups $(p=0.030)$. The number of lymphocytes on the fourth date varied significantly with diet; it was higher in the control protein groups $(\mathrm{p}=0.044)$.

The concentration of beta-hydroxybutyrate concentration in whole blood ranged from 0.2 to $0.7 \mathrm{mmol} / \mathrm{L}$. It did not vary significantly with diet or infection status, nor did it vary overtime significantly during the experiment. Its concentration remained inside the expected values for the species (Ermilio and Smith, 2011) .

\subsubsection{Number of Haemonchus contortus eggs in the faeces}

The not infected group of ewe lambs remained free of helminth eggs in their faeces during the whole experimental period. The number of eggs in the supplemented infected group varied from 0 to 3,350 (average of 657), and it varied from 0 to 5,400(average of 1,385) in the control infected group. The number of $H$. contortus eggs in their faeces did not vary significantly between protein supplemented and not supplemented infected groups.

\subsubsection{Results of RNA sequencing's raw data filtering}

The filtering removed the reads' adaptors, removed the reads in which more than $10 \%$ of its bases could not be identified, and removed the reads containing low-quality bases. The filtering removed 966967 (3.99\%) of reads adaptor-related, 510 reads containing $\mathrm{N}(0.00 \%)$ there were no reads removed because of low quality. The clean reads remaining after filtering were $23287287(96,01 \%)$ of the total.

\subsubsection{Sequencing data summary}

The total generated data was $153.3 \mathrm{G}$ raw data and $148.1 \mathrm{G}$ of filtered data-clean reads. The analysis identified 28.401 expressed genes. Statistical data for the sequencing quality can be visualised in Table 11. The number of sequences generated and sequencing depth in each sample are 
shown in Table 12. The percentage of mapping to gene regions can be seen in Table 13. The specificity of cDNA strand for each sample is in Table 14.

Table 11. Data generated by RNA sequencing

\begin{tabular}{cccccccccc}
\hline Sample & $\begin{array}{c}\text { Raw } \\
\text { Reads }\end{array}$ & $\begin{array}{c}\text { Clean } \\
\text { Reads }\end{array}$ & $\begin{array}{c}\text { Raw } \\
\text { Base(G) }\end{array}$ & $\begin{array}{c}\text { Clean } \\
\text { Base(G) }\end{array}$ & $\begin{array}{c}\text { Effective } \\
\text { Rate(\%) }\end{array}$ & $\begin{array}{c}\text { Error } \\
\text { Rate(\%) }\end{array}$ & Q20(\%) & Q30(\%) & $\begin{array}{c}\text { GC } \\
\text { Content(\%) }\end{array}$ \\
\hline B4 & 24254764 & 23287287 & 7.3 & 7.0 & 96.01 & 0.03 & 97.86 & 94.59 & 54.38 \\
B8 & 44927957 & 44419032 & 13.5 & 13.3 & 98.87 & 0.03 & 96.66 & 92.61 & 59.63 \\
A9 & 33463044 & 32569875 & 10.0 & 9.8 & 97.33 & 0.02 & 98.07 & 94.93 & 52.69 \\
A18 & 20745903 & 19471831 & 6.2 & 5.8 & 93.86 & 0.02 & 97.97 & 94.75 & 52.85 \\
A19 & 28202604 & 27983564 & 8.5 & 8.4 & 99.22 & 0.03 & 96.09 & 90.66 & 54.48 \\
A20 & 32232047 & 31370541 & 9.7 & 9.4 & 97.33 & 0.03 & 97.38 & 93.99 & 57.19 \\
B21 & 29113823 & 27363768 & 8.7 & 8.2 & 93.99 & 0.03 & 97.58 & 94.27 & 56.51 \\
B23 & 29536890 & 28869927 & 8.9 & 8.7 & 97.74 & 0.03 & 96.45 & 91.28 & 52.69 \\
B24 & 24821414 & 24244630 & 7.4 & 7.3 & 97.68 & 0.02 & 98.02 & 94.72 & 51.55 \\
A28 & 30591298 & 29980521 & 9.2 & 9.0 & 98.00 & 0.03 & 97.92 & 94.56 & 53.42 \\
A32 & 28459885 & 27334382 & 8.5 & 8.2 & 96.05 & 0.02 & 98.09 & 94.91 & 52.88 \\
A33 & 38037046 & 36050761 & 11.4 & 10.8 & 94.78 & 0.03 & 97.41 & 93.40 & 53.97 \\
A35 & 24058204 & 22874912 & 7.2 & 6.9 & 95.08 & 0.02 & 98.04 & 94.89 & 53.22 \\
A40 & 28344939 & 26734222 & 8.5 & 8.0 & 94.32 & 0.02 & 98.09 & 94.96 & 53.74 \\
C22 & 27175486 & 24885063 & 8.2 & 7.5 & 91.57 & 0.03 & 97.61 & 94.16 & 52.34 \\
B24_1 & 26497214 & 26099781 & 7.9 & 7.8 & 98.50 & 0.03 & 98.00 & 94.65 & 53.30 \\
B3 & 19073483 & 18755024 & 5.7 & 5.6 & 98.33 & 0.02 & 98.09 & 94.86 & 52.33 \\
A34 & 21526666 & 21229329 & 6.5 & 6.4 & 98.62 & 0.02 & 98.62 & 95.94 & 52.10 \\
\hline
\end{tabular}

\subsubsection{Distribution of the $A / T / G / C$ bases}

This distribution is used to identify the separation of AT and GC when the distribution of the GC content is verified. According to the principle of complementarity between bases, AT and GC's content should be equal in every sequencing cycle and be constant and stable in the whole sequencing procedure. Due to the tendency of the primer's amplification, the first six or seven nucleotides fluctuate. The distribution of the GC content is shown in Figure 15. 


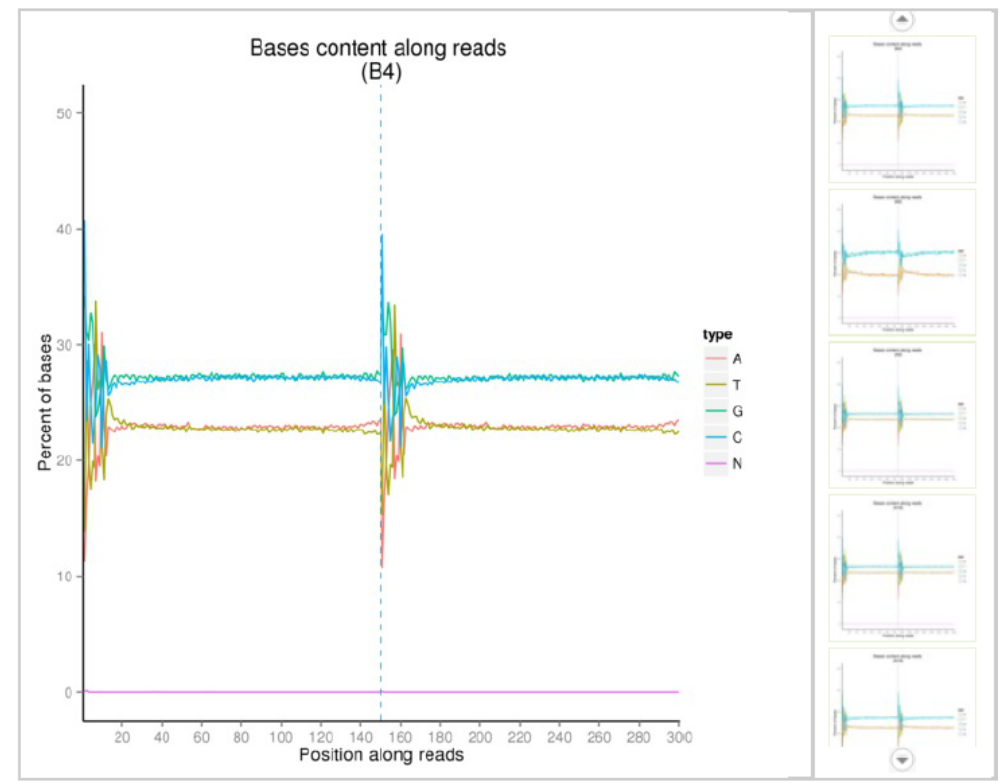

Figure 15. Distribution $A / T / G / C$. The position of the sequenced base is in the horizontal axis and the percentage of the single base is in the vertical axis.

Table 12. Number of sequences and Sequencing depth generated by RNA sequencing

\begin{tabular}{ccc}
\hline $\begin{array}{c}\text { Sample/Animal } \\
\text { Identification }\end{array}$ & $\begin{array}{l}\text { Number of } \\
\text { generated } \\
\text { sequences }\end{array}$ & $\begin{array}{c}\text { Sequencing } \\
\text { depth(X) }\end{array}$ \\
\hline A18 & 40.226 .422 & 4,7 \\
A35 & 48.116 .408 & 5,6 \\
B4 & 48.509 .528 & 5,7 \\
A32 & 56.919 .770 & 6,7 \\
A9 & 66.926 .088 & 7,8 \\
B3 & 38.146 .966 & 4,5 \\
A34 & 43.053 .332 & 5,0 \\
A28 & 61.182 .596 & 7,2 \\
B8 & 46.062 .480 & 5,4 \\
A19 & 56.405 .208 & 6,6 \\
A33 & 73.152 .548 & 8,6 \\
B24 & 49.642 .828 & 5,8 \\
B23 & 59.073 .780 & 6,9 \\
A20 & 44.524 .258 & 5,2 \\
A40 & 55.056 .536 & 6,4 \\
B21 & 41.889 .154 & 4,9 \\
C22 & 54.350 .972 & 6,4 \\
\hline & &
\end{tabular}


Table 13. Percentage of mapping to gene regions

\begin{tabular}{llll}
\hline $\begin{array}{l}\text { Sample/Animal } \\
\text { Identification }\end{array}$ & $\begin{array}{l}\text { Mapped to gene } \\
\text { regions (\%) }\end{array}$ & $\begin{array}{l}\text { Mapped to intergenic } \\
\text { regions (\%) }\end{array}$ & Messenger RNA (\%) \\
\hline A18 & 95,05 & 4,95 & 95 \\
A35 & 95,19 & 4,81 & 93 \\
B4 & 95,39 & 4,61 & 84 \\
A32 & 94,63 & 5,37 & 92 \\
A9 & 94,41 & 5,59 & 92 \\
B3 & 94,93 & 5,07 & 94 \\
A34 & 94,33 & 5,67 & 92 \\
A28 & 95,02 & 4,98 & 89 \\
B8 & 93,33 & 6,67 & 73 \\
A19 & 96,39 & 3,61 & 76 \\
A33 & 95,63 & 4,37 & 86 \\
B24 & 95,08 & 4,92 & 91 \\
B23 & 95,29 & 4,71 & 91 \\
A20 & 94,58 & 5,42 & 80 \\
A40 & 96,18 & 3,82 & 81 \\
B21 & 94,95 & 5,05 & 86 \\
C22 & 85,99 & 14,01 & 87 \\
\hline
\end{tabular}

Table 14. Specificity of DNA strand

\begin{tabular}{lll}
\hline $\begin{array}{l}\text { Sample/Animal } \\
\text { Identification }\end{array}$ & \% of the reads mapped in forward sense & $\begin{array}{l}\text { \% of the reads mapped in reverse } \\
\text { sense }\end{array}$ \\
\hline A18 & 50,51 & 49,49 \\
A35 & 50,38 & 49,62 \\
B4 & 50,46 & 49,54 \\
A32 & 50,18 & 49,82 \\
A9 & 50,38 & 49,62 \\
B3 & 50,07 & 49,93 \\
A34 & 49,94 & 50,06 \\
A28 & 50,35 & 49,65 \\
B8 & 50,28 & 49,72 \\
A19 & 50,44 & 49,56 \\
A33 & 50,31 & 49,69 \\
B24 & 50,42 & 49,58 \\
B23 & 50,47 & 49,53 \\
A20 & 50,25 & 49,75 \\
A40 & 50,24 & 49,76 \\
B21 & 50,61 & 49,39 \\
C22 & 50,34 & 49,66 \\
\hline
\end{tabular}




\subsubsection{RNAseq differential expression analysis}

\subsubsection{Differentially expressed genes in the comparisons Supplemented Not Infected vs} Control Not Infected groups and Supplemented Infected vs Control Infected groups

The comparison between groups Supplemented Not Infected vs Control Not Infected generated a list of 1927 differentially expressed up-regulated genes and 2504 down-regulated genes.

Supplemented Infected vs Control Infected comparison produced a list of 2187 differentially expressed up-regulated genes and 2304 down-regulated genes.

The comparison between groups Control Infected vs Supplemented Infected generated a list of 2304 differentially expressed up-regulated genes and 2186 down-regulated genes. The full list of these genes is in Additional Information section.

Some of the up-regulated genes found in the comparisons Supplemented Not Infected vs Control Not Infected and Supplemented Infected vs Control Infected are shown in Table 15.

Some of the up-regulated genes found in the comparisons Control not Infected vs Supplemented not Infected and Control Infected vs Supplemented Infected are shown in Table 16.

In figure 26 we pictured common and uniquely processes found enriched in the in the upregulated gene lists of the comparisons Supplemented not Infected vs Control not Infected and Supplemented Infected vs Control Infected.

In figure 27 we pictured common and uniquely processes found enriched in the downregulated gene lists of the comparisons Supplemented not Infected vs Control not Infected and Supplemented Infected vs Control Infected. 
Table 15: Up-regulated genes in the comparisons Supplemented not Infected vs Control not Infected and Supplemented Infected vs Control Infected

\begin{tabular}{|c|c|c|c|c|}
\hline Gene ID & Gene name /Function & GO/Biological processes/Pathways & $\begin{array}{l}\text { Supplemented } \\
\text { not Infected vs } \\
\text { Control not } \\
\text { Infected } \\
\text { (log fold } \\
\text { change) }\end{array}$ & $\begin{array}{l}\text { Supplemented } \\
\text { Infected vs } \\
\text { Control } \\
\text { Infected } \\
\text { (log fold } \\
\text { change) }\end{array}$ \\
\hline INHBA & Inhibin subunit beta $A$ & $\begin{array}{l}\text { Gamete generation (GO:0007276); } \\
\text { Developmental process involved in reproduction (GO:0003006); } \\
\text { First menstruation in humans }\end{array}$ & 5.1 & 2.5 \\
\hline FST & Follistatin & $\begin{array}{c}\text { Gamete generation (GO:0007276); } \\
\text { Developmental process involved in reproduction (GO:0003006); } \\
\text { Body height (Dbgap - Ncbi). }\end{array}$ & 3.5 & 5.8 \\
\hline HSD17B1 & $\begin{array}{l}\text { hydroxysteroid 17-beta } \\
\text { dehydrogenase }\end{array}$ & $\begin{array}{l}\text { Estrogen biosynthesis process (GO:0006703); } \\
\text { Estrogen metabolic process (GO:0008210); } \\
\text { Cell hormonal metabolism process (GO:0034754) }\end{array}$ & 1.3 & 6.4 \\
\hline $\mathrm{EZH} 2$ & $\begin{array}{l}\text { enhancer of zeste } 2 \text { polycomb } \\
\text { repressive complex } 2 \text { subunit }\end{array}$ & $\begin{array}{l}\text { Repression of the transcription (GO:0098532); } \\
\text { G2M checkpoint (Hallmark) }\end{array}$ & 1.2 & 1.8 \\
\hline FBXO5 & F-BOX protein 5 & $\begin{array}{l}\text { Spindle assembly involved in female meiosis (GO:0007057); } \\
\text { Negative regulation of DNA endoreduplication (GO:0032876) }\end{array}$ & 1.6 & 2.7 \\
\hline AURKA & Aurora kinase & $\begin{array}{l}\text { Oocyte meiosis(hsa04114); Positive regulation of oocyte maturation (GO:1900195); } \\
\text { Spindle assembly involved in female meiosis I (GO:0007057) }\end{array}$ & 1.6 & 1.9 \\
\hline PLK1 & Polo like kinase 1 & $\begin{array}{l}\text { Oocyte meiosis(hsa04114); Progesterone-mediated oocyte maturation(hsa04914); } \\
\text { Mitotic spindle assembly checkpoint(GO:0007094) }\end{array}$ & 1.3 & 2.1 \\
\hline
\end{tabular}




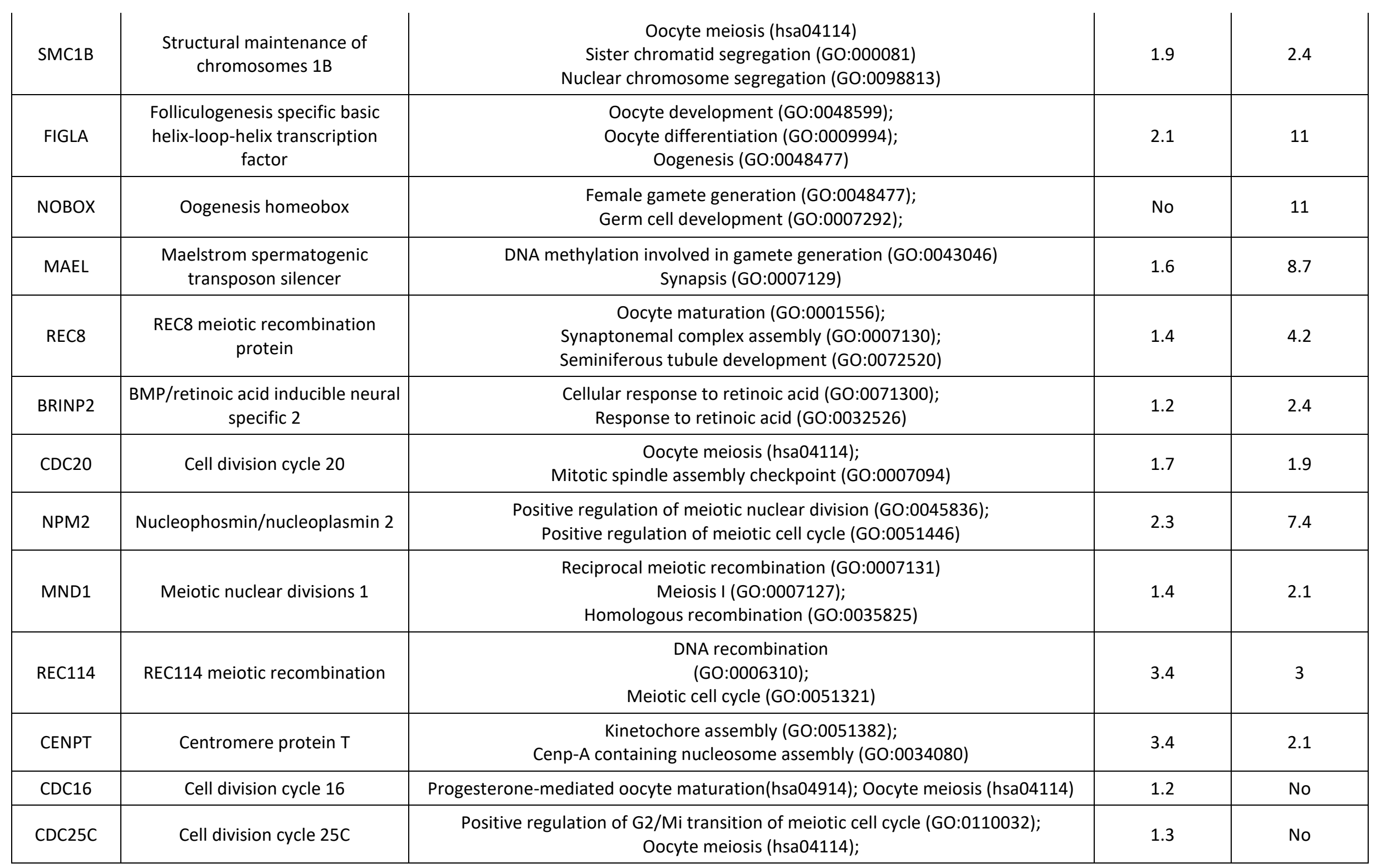




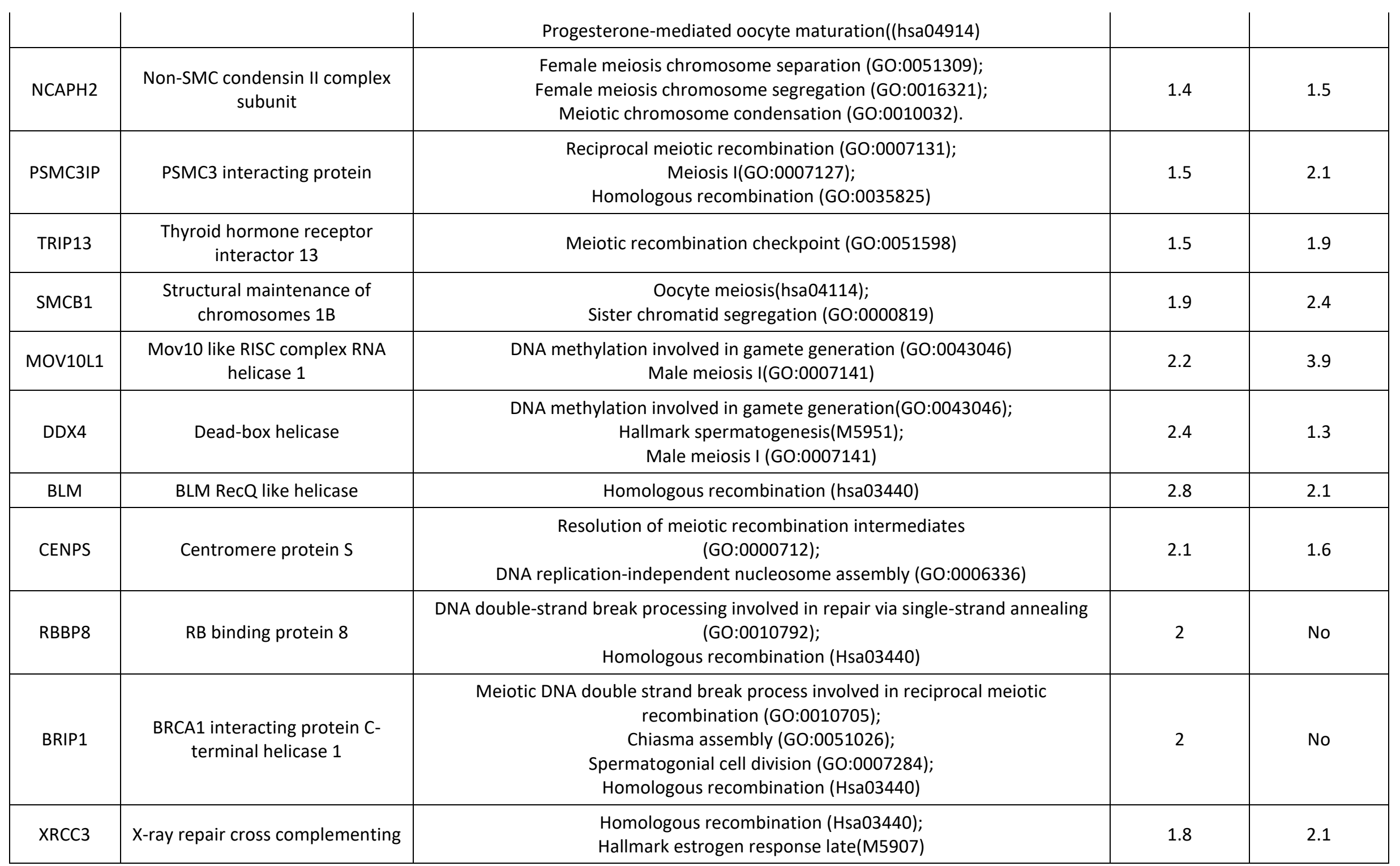




\begin{tabular}{|c|c|c|c|c|}
\hline FANCD2 & FA complementation group D2 & Double-strand break repair involved in meiotic recombination (GO:1990918) & 1.6 & 1.8 \\
\hline BUB1 & $\begin{array}{l}\text { BUB1 mitotic checkpoint } \\
\text { serine/threonine kinase }\end{array}$ & $\begin{array}{l}\text { Meiotic sister chromatid cohesion, centromeric (GO:0051754); } \\
\text { Oocyte meiosis(Hsa04114); } \\
\text { Progesterone-mediated oocyte maturation(hsa04914); } \\
\text { Hallmark spermatogenesis(M5951); } \\
\text { Hallmark MTORC1 signaling(M5924) }\end{array}$ & 1.7 & 1.8 \\
\hline LRCOL1 & Leucine rich colipase like & $\begin{array}{l}\text { Response to food (GO:0032094); } \\
\text { Digestion(GO:0007586); } \\
\text { Lipid catabolic process( GO:0016042) }\end{array}$ & 10 & No \\
\hline NUCB2 & Nucleobinding 2 & $\begin{array}{l}\text { Negative regulation of appetite (GO:0032099); } \\
\text { Negative regulation of response to food (GO:0032096); } \\
\text { Negative regulation of response to nutrient level (GO:0032108) }\end{array}$ & 1.4 & No \\
\hline CLPSL2 & Colipase like 2 & $\begin{array}{l}\text { Response to food (GO:0032094); } \\
\text { Digestion (GO:0007586); } \\
\text { Lipid catabolic process (GO:0016042) }\end{array}$ & 1.3 & No \\
\hline LHX8 & LIM homeobox 8 & Female gonad development (GO:0008585) & No & 10 \\
\hline NOBOX & NOBOX oogenesis homeobox & Female gamete generation (GO:0007292); & No & 11 \\
\hline
\end{tabular}




\begin{tabular}{|c|c|c|c|c|}
\hline & & Germ cell development (GO:0007281) & & \\
\hline SOHLH1 & $\begin{array}{l}\text { spermatogenesis and oogenesis } \\
\text { specific basic helix-loop-helix } 1\end{array}$ & $\begin{array}{c}\text { Oocyte differentiation } \\
\text { (GO:0009994); } \\
\text { Oogenesis (GO:0048477); } \\
\text { Spermatogenesis (GO:0007283) }\end{array}$ & No & 8.5 \\
\hline Foxl2 & forkhead box L2 & Positive regulation of gonadotropin secretion (GO:0032278) & No & 4.8 \\
\hline FSHR & $\begin{array}{l}\text { Receptor for follicle stimulating } \\
\text { hormone }\end{array}$ & $\begin{array}{l}\text { Cellular response to follicle-stimulating hormone stimulus (GO:0071372); } \\
\text { Ovarian follicle development (GO:0001541) }\end{array}$ & No & Yes $(+2.9)$ \\
\hline STAR & $\begin{array}{l}\text { Steroidogenic acute regulatory } \\
\text { protein }\end{array}$ & $\begin{array}{c}\text { Circadian sleep/wake cycle, REM sleep (GO:0042747); } \\
\text { Ovarian steroidogenesis(hsa04913) }\end{array}$ & No & Yes $(+2.2)$ \\
\hline CYP17A1 & $\begin{array}{l}\text { Cytochrome P450 family } 17 \\
\text { subfamily A member } 1\end{array}$ & Progesterone metabolic process (GO:0042448) & No & Yes $(+4.1)$ \\
\hline CYP11A1 & $\begin{array}{l}\text { Cytochrome P450 family } 11 \\
\text { subfamily A member } 1\end{array}$ & $\begin{array}{c}\text { GO:0006700 C21-steroid hormone biosynthetic process; } \\
\text { Ovarian steroidogenesis(hsa04913) }\end{array}$ & No & Yes $(+2.4)$ \\
\hline LHCGR & $\begin{array}{c}\text { Luteinizing } \\
\text { hormone/choriogonadotropin } \\
\text { receptor }\end{array}$ & Cellular response to luteinizing hormone stimulus (GO:0071373) & No & Yes $(+1.3)$ \\
\hline VEGF-A & $\begin{array}{l}\text { Vascular endothelial growth } \\
\text { factor A }\end{array}$ & VEGF signaling pathway (hsa04370) & $\operatorname{Yes}(2.2)$ & Yes $(+2.5)$ \\
\hline
\end{tabular}

Table 16. Up-regulated genes in the comparisons Control not Infected vs Supplemented not Infected and Control Infected vs Supplemented Infected 


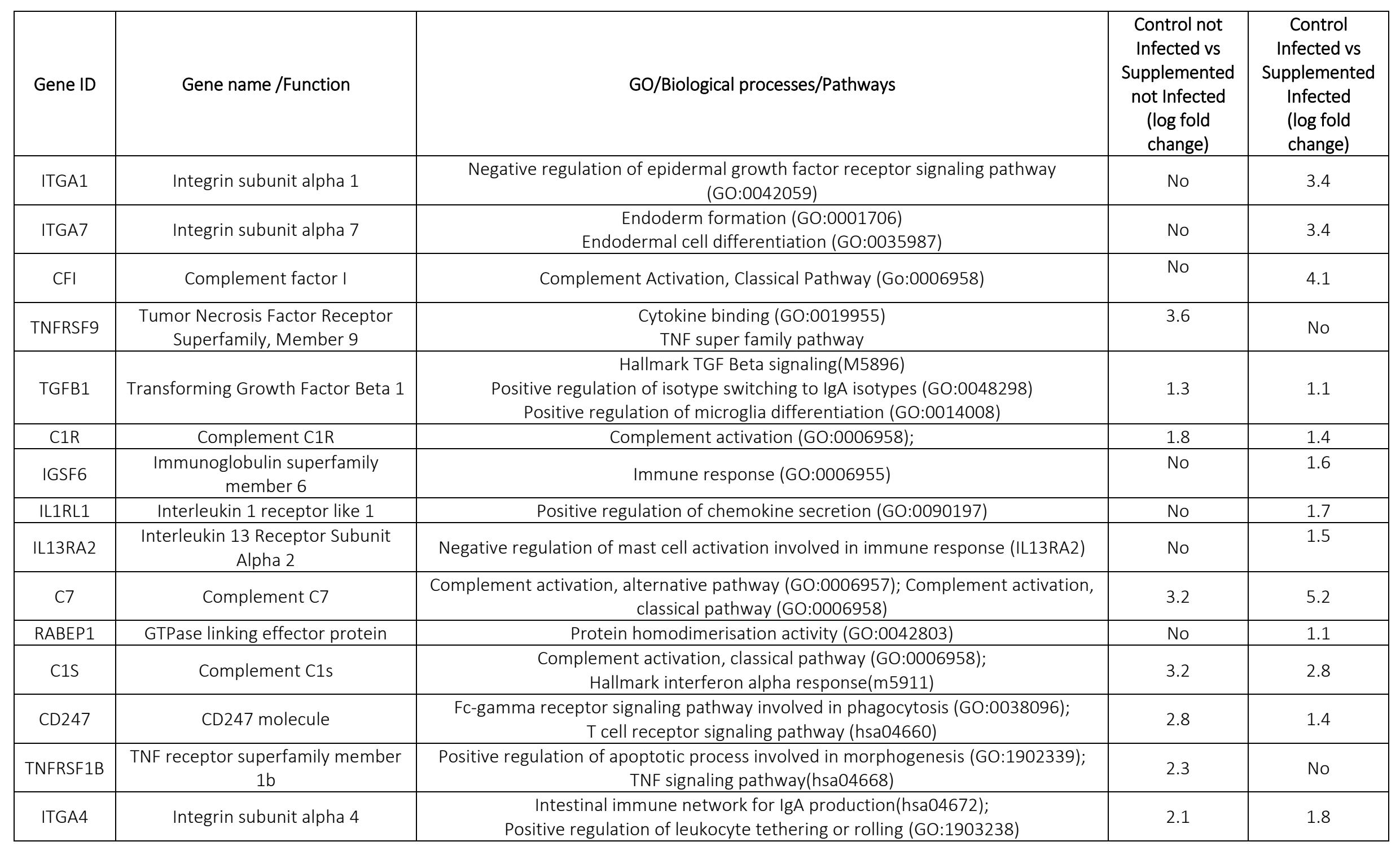




\begin{tabular}{|c|c|c|c|}
\hline TNFSF13B & $\begin{array}{c}\text { Tumor Necrosis Factor (Ligand) } \\
\text { Superfamily, Member 13b }\end{array}$ & TNF receptor binding (GO:0005164) & 3.6 \\
\hline TNFSF8 & $\begin{array}{c}\text { Tumor Necrosis Factor Ligand } \\
\text { Superfamily Member 8 }\end{array}$ & $\begin{array}{c}\text { TNF receptor binding (GO:0005164) } \\
\text { Signalling receptor binding (GO:0005102) }\end{array}$ & 1.4 \\
\hline
\end{tabular}




\subsubsection{Enriched pathways and biological processes in the differentially expressed genes}

\subsection{Comparison between Supplemented Not Infected vs Control Not Infected groups}

We analysed the genes differentially expressed in the comparison between Supplemented Not Infected vs Control Not Infected to find the differentially expressed genes in the ewe lambs ovary due only to the diet's level of protein. This comparison generated a list of up-regulated 1927 differentially expressed genes and 2504 differentially down-regulated genes. We searched on both gene lists to find which pathways and biological processes terms were enriched (Figures 16 and 17).

In the up - regulated gene list, among other terms/biological processes, we found enriched : Meiotic cell cycle (GO - 0051321), DNA recombination (GO: 0006310); DNA methylation involved in gamete generation (GO:0043046), Regulation of meiotic nuclear division (GO: 0040020), DNA Replication (GO: 0006260), Meiotic cell cycle phase transition (GO:0044771),Sister chromatid cohesion (GO: 0007062); Kinetochore organisation (GO: 0051383), Male meiosis I (GO:0007141), Regulation of response to DNA damage stimulus (GO:2001020), regulation of DNA endoreduplication (GO: 0032875), Positive regulation of smoothened signaling pathway (GO:0045880), Response to food (GO: 0032094), Hallmark MTORC1 Signaling (M5924), Circadian behaviour (GO:0048512), Hallmark Estrogen Response Late (M5907); Hallmark Spermatogenesis (M5951); the full list of terms found enriched in the up-regulated genes with their respective - $\log 10$ (p-values) is in Figure 3. Also, in Figure 4 a subset of these enriched terms is pictured in a different perspective to show the connections among processes, each term is pictured by a node, where its size is proportional to the number of genes belonging to this term. Terms with a Kappa similarity larger than 0.3 are connected by borders. The nodes are coloured by cluster ID, where nodes that share the same cluster ID are generally close to each other.

\subsection{Comparison between Control Not Infected vs Supplemented Not Infected groups}

This comparison generated a list of 2513 up-regulated genes and 1961 down regulated genes. In the up-regulated gene list, among other terms/biological processes we found enriched: Macrophage activation(GO:0042116), Leukocyte Migration(GO: 0050900), Regulation of Cytokine Production(GO: 0001817); Myeloid leukocyte activation(GO:0002274),Leukocyte proliferation (GO: 0070661), Hallmark Complement(M5921), Hallmark Inflammatory response(M5932), Cellular response to Growth Factor stimulus(GO: 0071363), Developmental Growth (GO:0048589), Developmental growth involved in morphogenesis (GO:0060560), Regulation of Cell Adhesion(GO: 0030155), Negative Regulation Of Cell Adhesion(GO:0007162); Extracellular matrix organisation (GO:0030198), 
Blood vessel development(GO: 0001568); the full list of terms found enriched in the up-regulated genes with their respective $-\log 10$ (p-values) is in Figure 18. Also, in Figure 19 a subset of these enriched terms is pictured in a different perspective to show the connections among processes, each term is pictured by a node, where its size is proportional to the number of genes belonging to this term. Terms with a Kappa similarity larger than 0.3 are connected by borders. The nodes are colored by cluster ID, where nodes that share the same cluster ID are generally close to each other. 


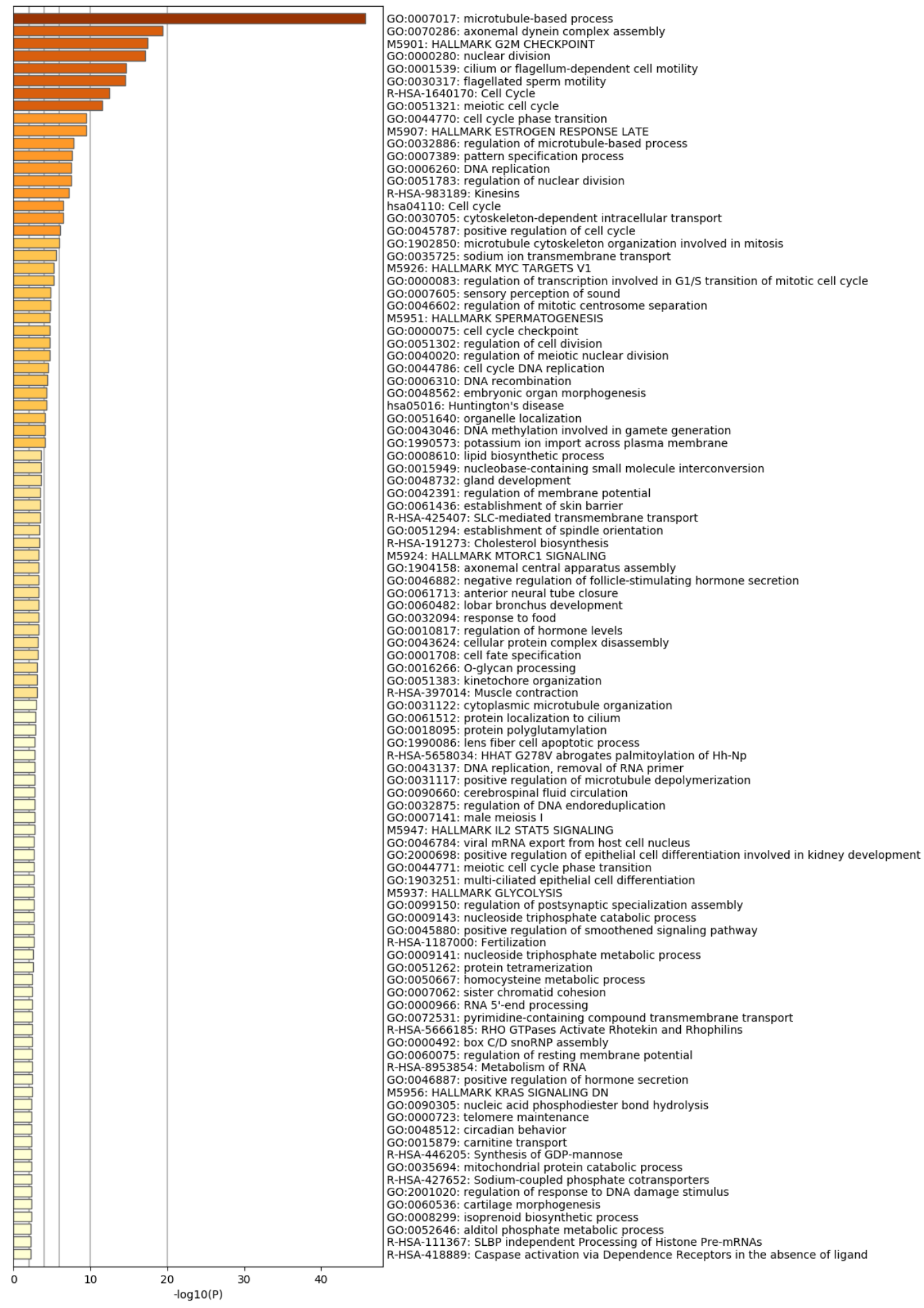

Figure 16. Enriched terms in the list of differentially up-regulated genes between the groups Supplemented Not Infected and Control Not Infected. *The hypergeometric accumulated p-values and enrichment factors were calculated and used for filtering. The significant terms that remained after filtering were hierarchically grouped in a tree based on Statistical similarity Kappa. The score Kappa 0.3 was applied as threshold to fuse the tree. 

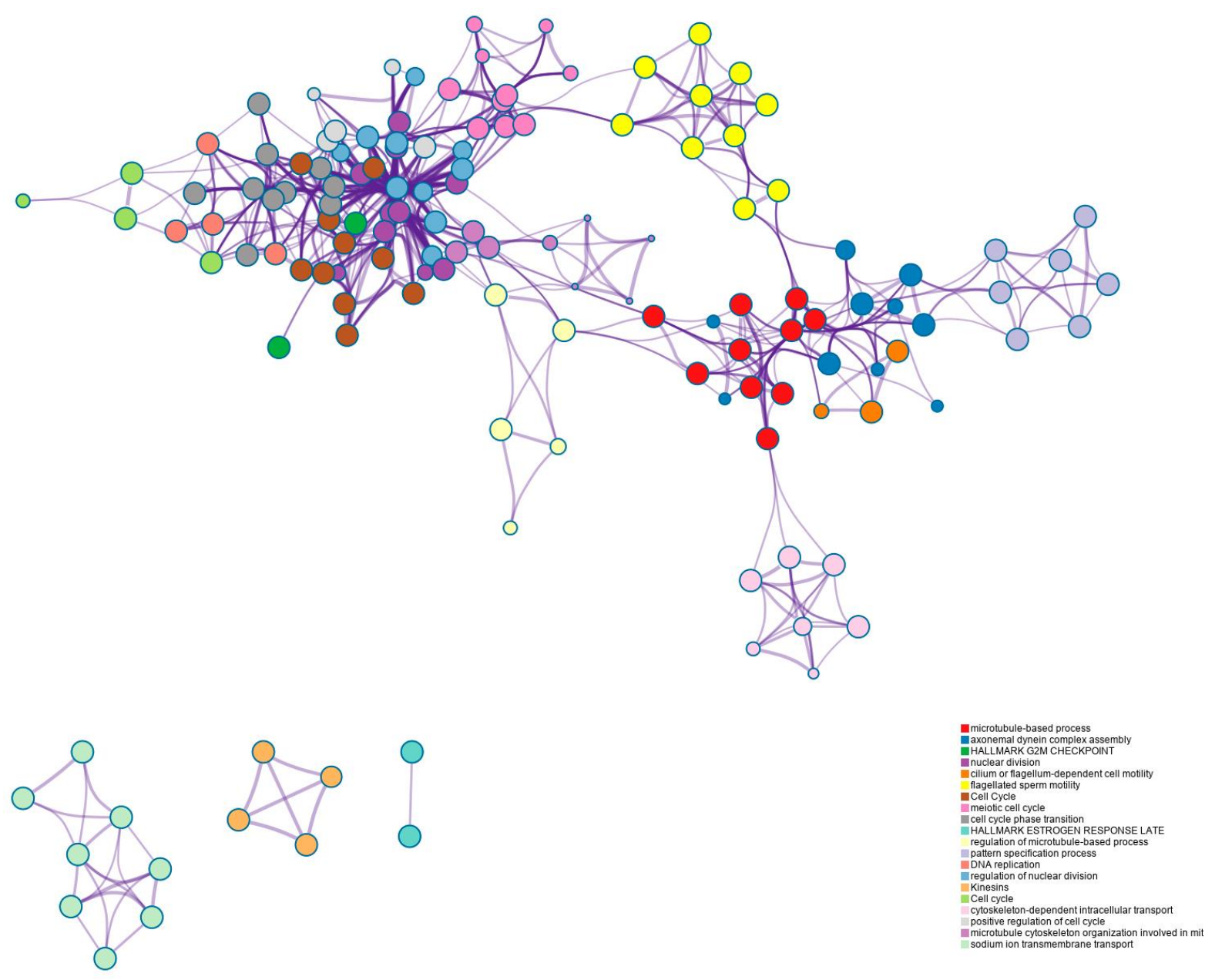

Figure 17. Subset of enriched terms in the list of differentially up regulated genes between the groups Supplemented not Infected vs Control Not Infected. *Each term is represented by a node, its size is proportional to the number of genes belonging to this term. Terms with a similarity larger than 0.3 are connected by borders, they have the best $\mathrm{p}$-values from each of the 20 clusters. There are no more than 15 terms per cluster and no more than 250 terms in total. The nodes are coloured by cluster ID, where nodes that share the same cluster ID are generally close to each other. 


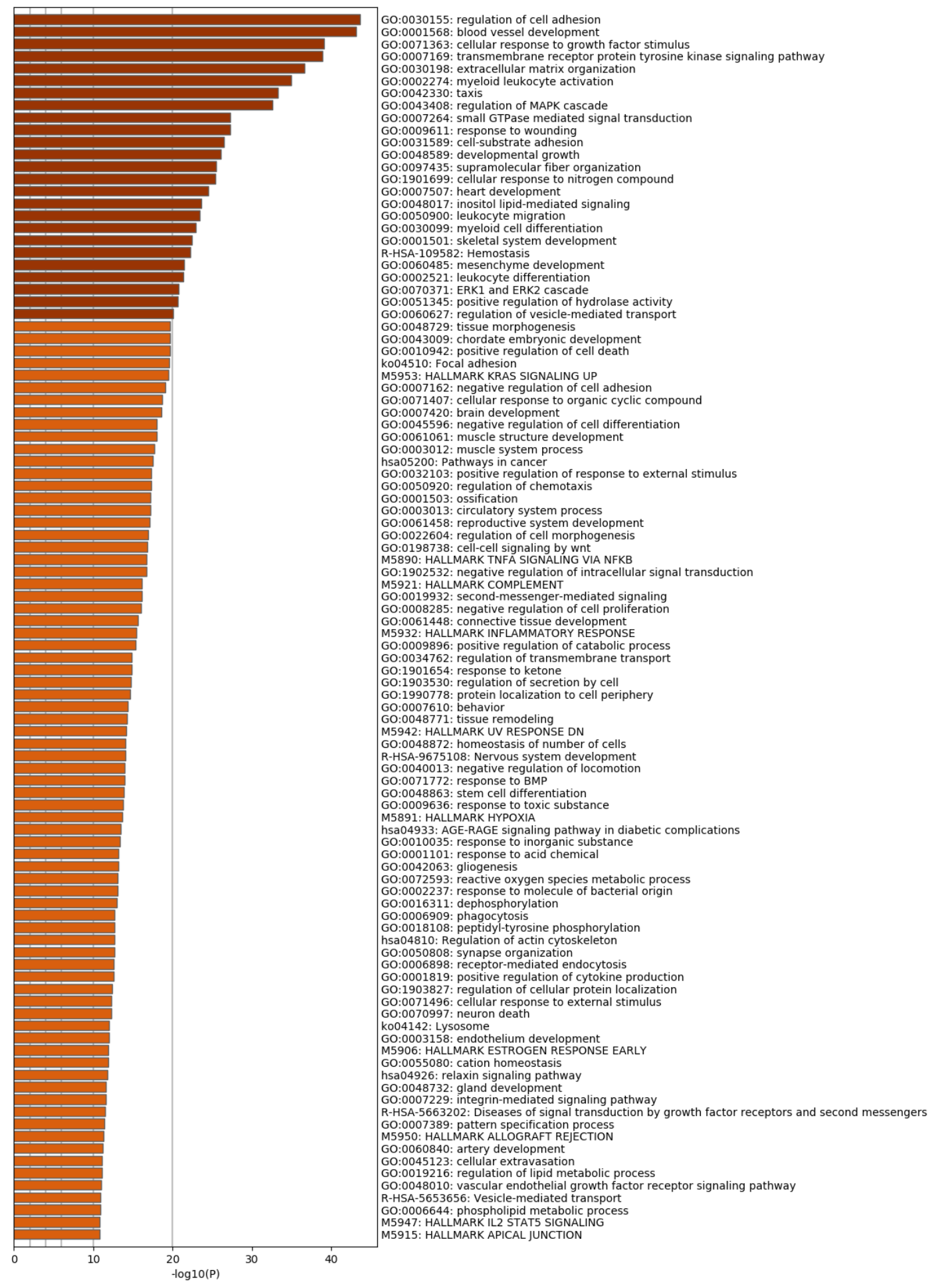

Figure 18. Enriched terms in the list of differentially up-regulated genes between Control Not Infected vs Supplemented Not Infected.* The hypergeometric accumulated p-values and enrichment factors were calculated and used for filtering. The significant terms that remained after filtering were hierarchically grouped in a tree based on Statistical similarity Kappa. The score Kappa 0.3 was applied as threshold to fuse the tree in terms grouping. 


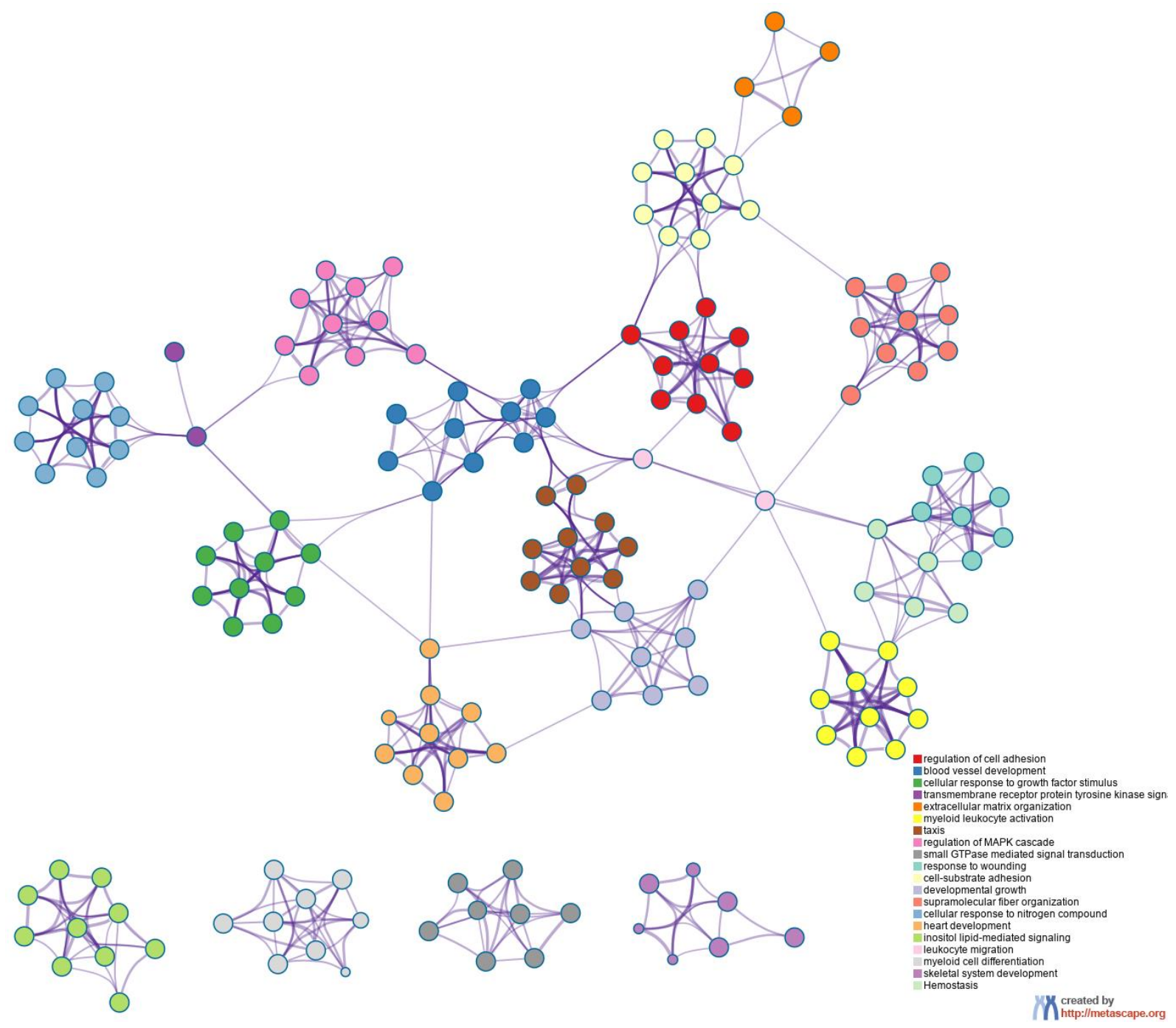

Figure 19. Subset of enriched terms in the list of differentially up-regulated genes between the groups Control Not Infected vs Supplemented Not Infected. *Each term is represented by a node, its size is proportional to the number of genes belonging to this term. Terms with a similarity larger than 0.3 are connected by borders, they have the best p-values from each of the 20 clusters. There are no more than 15 terms per cluster and no more than 250 terms in total. The nodes are colored by cluster ID, where nodes that share the same cluster ID are generally close to each other. 


\subsection{Comparison between Supplemented Infected vs Control Infected} groups

We analysed the lists of genes differentially expressed in the comparison Supplemented Infected vs Control Infected to find the enriched pathways in the ewe lambs' ovary due to the difference of protein's level in the diet in the presence of an infection. This comparison generated a list of 2187 differentially up-regulated genes and 2304 differentially down-regulated genes. We analysed both gene lists to find which pathways and biological processes terms were enriched (Figures 20 and 21).

Among other biological processes and pathways enriched in the up-regulated genes list, we found: Meiotic nuclear division(GO:0140013), Female gamete generation(GO:0007292), Double-strand break repair via break induced replication(GO: 0000727), HDR through Homologous recombination(R-HSA-5685942), DNA biosynthetic process(GO:0071897), Oocyte meiosis(hsa04114),Establishment of Chromosome localization (GO:0051303), Methylation(GO: 0032259), DNA conformation change(GO:0071103), Hallmark E2F targets (M5925), DNA dependent DNA replication(GO: 0006261), DNA replication (R-HSA-69306), Ribosome biogenesis(GO:0042254), Hallmark MTORC1 Signaling(M5924); the full list of enriched biological processes and pathways terms in up-regulated genes is in Figure 7. Also, in Figure 8 a subset of these enriched terms is pictured in a different perspective to show the connections among processes, each term is pictured by a node, where its size is proportional to the number of genes belonging to this term. Terms with a Kappa similarity larger than 0.3 are connected by borders. The nodes are coloured by cluster ID, where nodes that share the same cluster ID are generally close to each other.

\subsubsection{Comparison between Control Infected vs Supplemented Infected groups}

This comparison generated a list of 2304 up-regulated genes and 2186. Among other biological processes and pathways enriched in the up-regulated genes list, we found: Leukocyte migration (GO:0050900), Regulation of cytokine production (GO:0001817), Hallmark Inflammatory response (M5932), Negative regulation of Immune system process (GO:0002683), Hallmark IL2 STAT5 signaling (M5947), Hallmark KRAS signaling up (M5953), Cytokine mediated signaling pathway (GO:0019221), Cytokine-cytokine receptor interaction (hsa04060), Hallmark TNFA signaling via NFKB (M5890), Inositol lipid mediated signaling (GO: 0048017), Alpha-beta T cell activation (GO:0046631), Chemokine signaling pathway (hsa04060), Regulation of cell adhesion (GO:0030155), Extracellular matrix organization (GO:0030198), Blood vessel development (GO:0001568), Tissue morphogenesis (GO: 0048729), Response to growth factor (GO:0070848), Wound healing (GO:0042060), Tissue remodelling (GO:0048771), Artery development (GO:0060840) and Endothelium development (GO: 0003158); the full list of enriched biological processes and pathways terms in up-regulated genes is in Figure 22. Also, in Figure 23 a subset of these enriched terms was pictured in a different perspective to show the connections among processes, each term is pictured by a node, where its size is proportional to the number of genes belonging to this term. Terms with a similarity larger than 0.3 are connected by borders. The nodes are coloured by cluster ID, where nodes that share the same cluster ID are generally close to each other. 


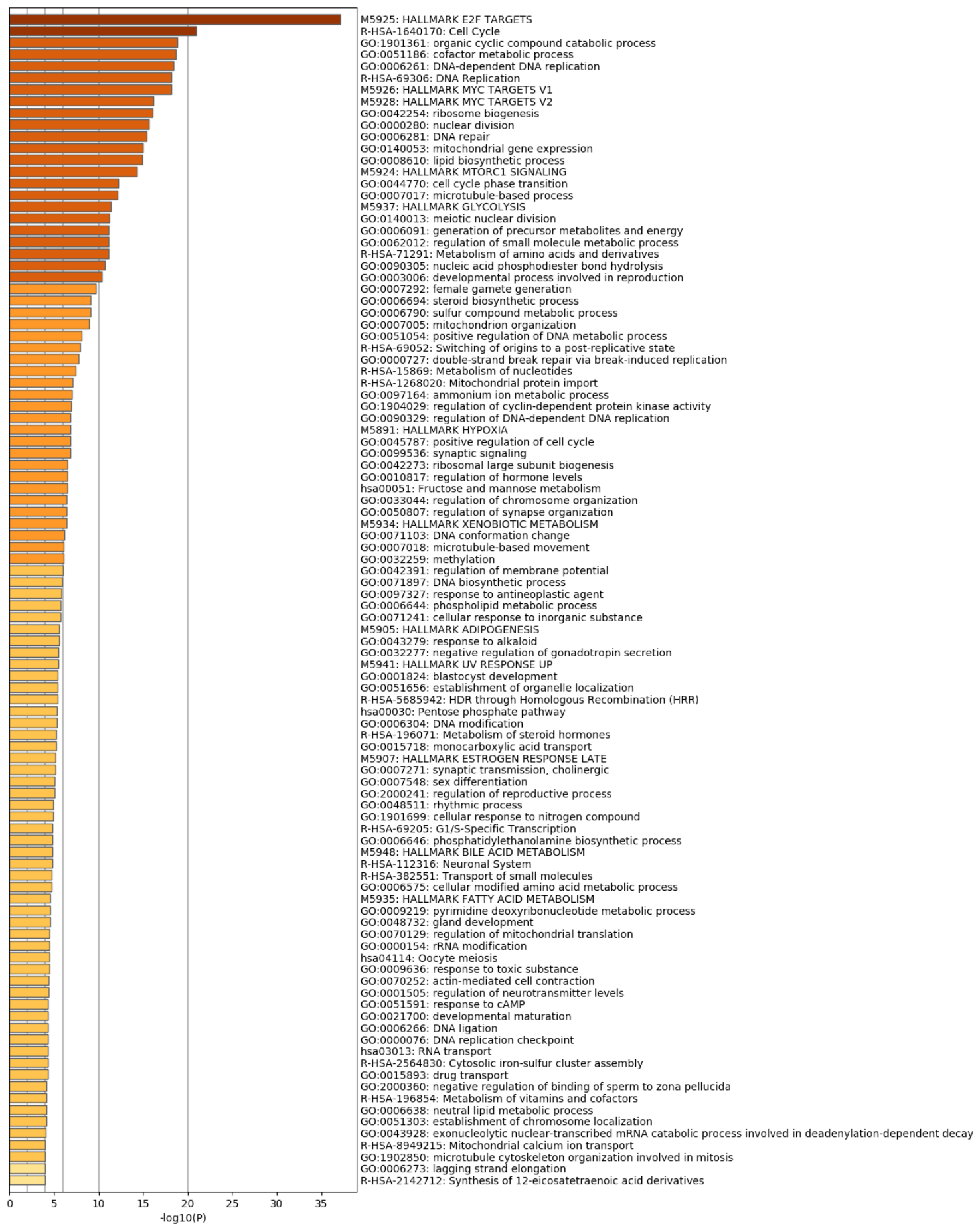

Figure 20. Enriched terms in the list of differentially up-regulated genes between the groups Supplemented Infected and Control Infected. The hypergeometric accumulated p-values and enrichment factors were calculated and used for filtering. The significant terms that remained after filtering were hierarchically grouped in a tree based on Statistical similarity Kappa. The score Kappa 0.3 was applied as threshold to fuse the tree in terms grouping 


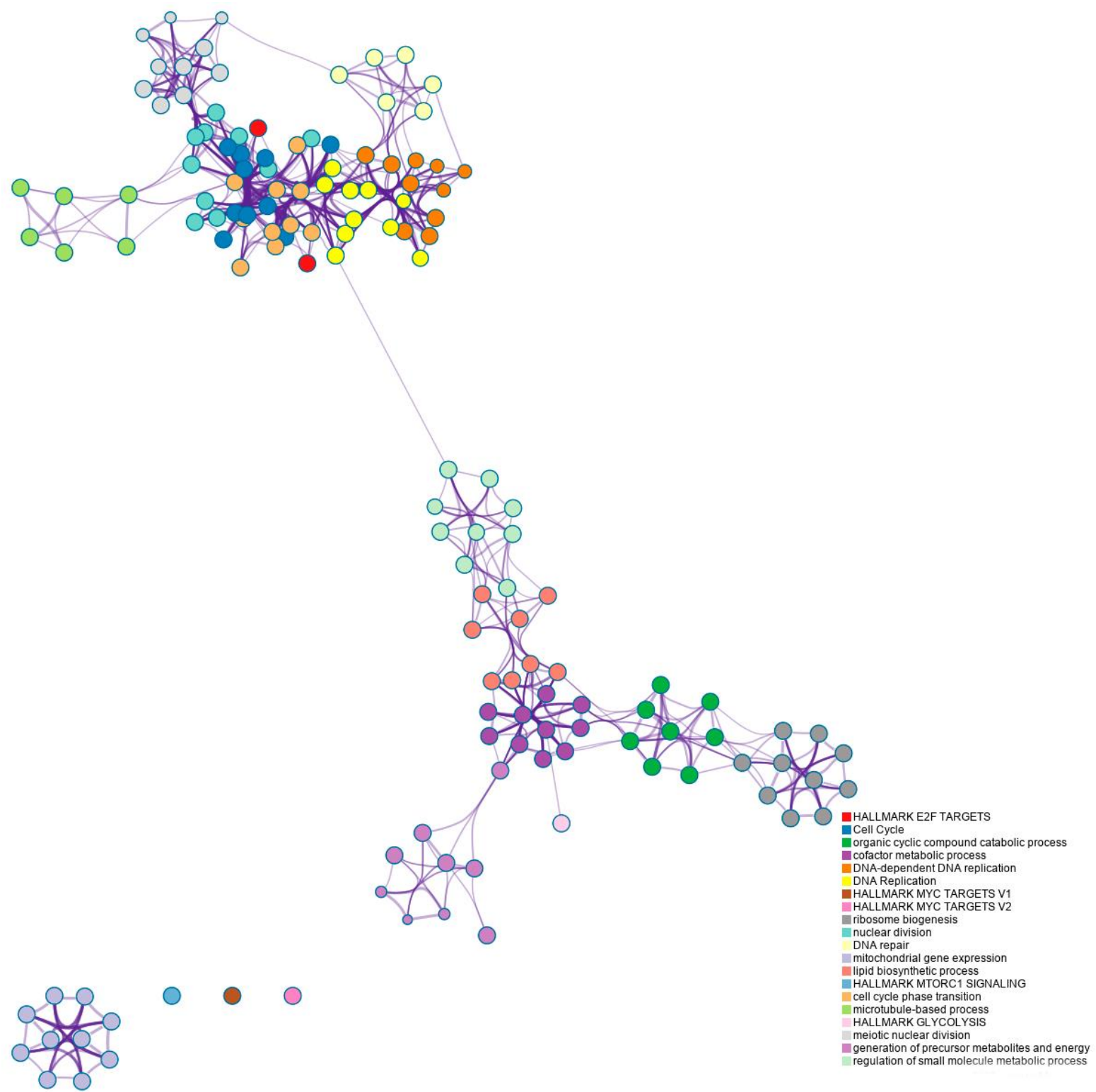

Figure 21. Subset of enriched terms in the list of differentially up-regulated genes between the groups Supplemented Infected and Not Supplemented Infected. Each term is represented by a node, its size is proportional to the number of genes belonging to this term. Terms with a similarity larger than 0.3 are connected by borders. Terms represented here have the best p-values from each of the 20 clusters. There are no more than 15 terms per cluster and no more than 250 terms in total. The nodes are colored by cluster ID, where nodes that share the same cluster ID are generally close to each other. 


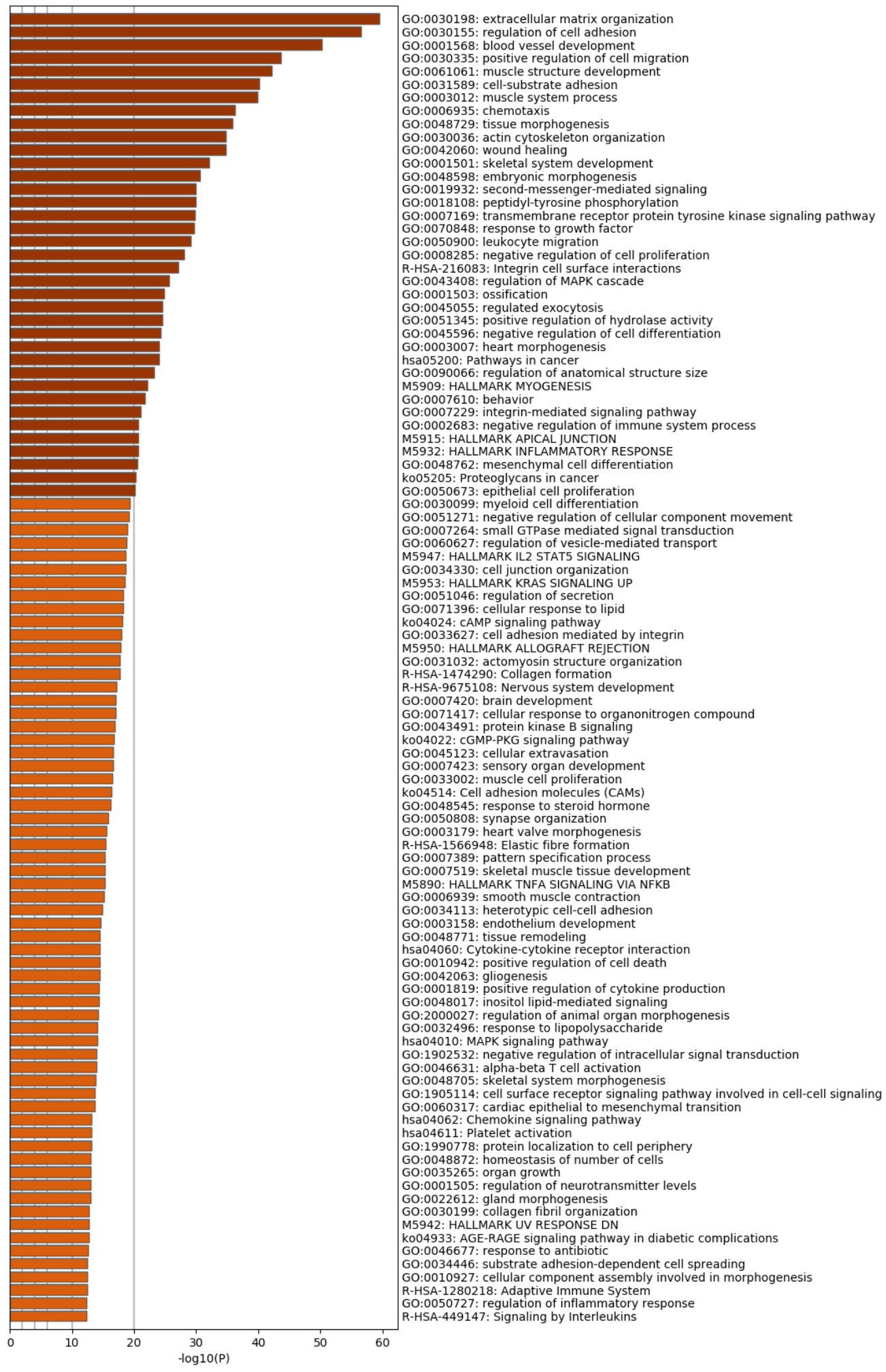

Figure 22. Enriched terms in the list of differentially up-regulated genes between the groups Control Infected vs Supplemented Infected. The hypergeometric accumulated p-values and enrichment factors were calculated and used for filtering. The significant terms that remained after filtering were hierarchically grouped in a tree based on Statistical similarity Kappa. The score Kappa 0.3 was applied as a threshold to fuse the tree in terms grouping. 


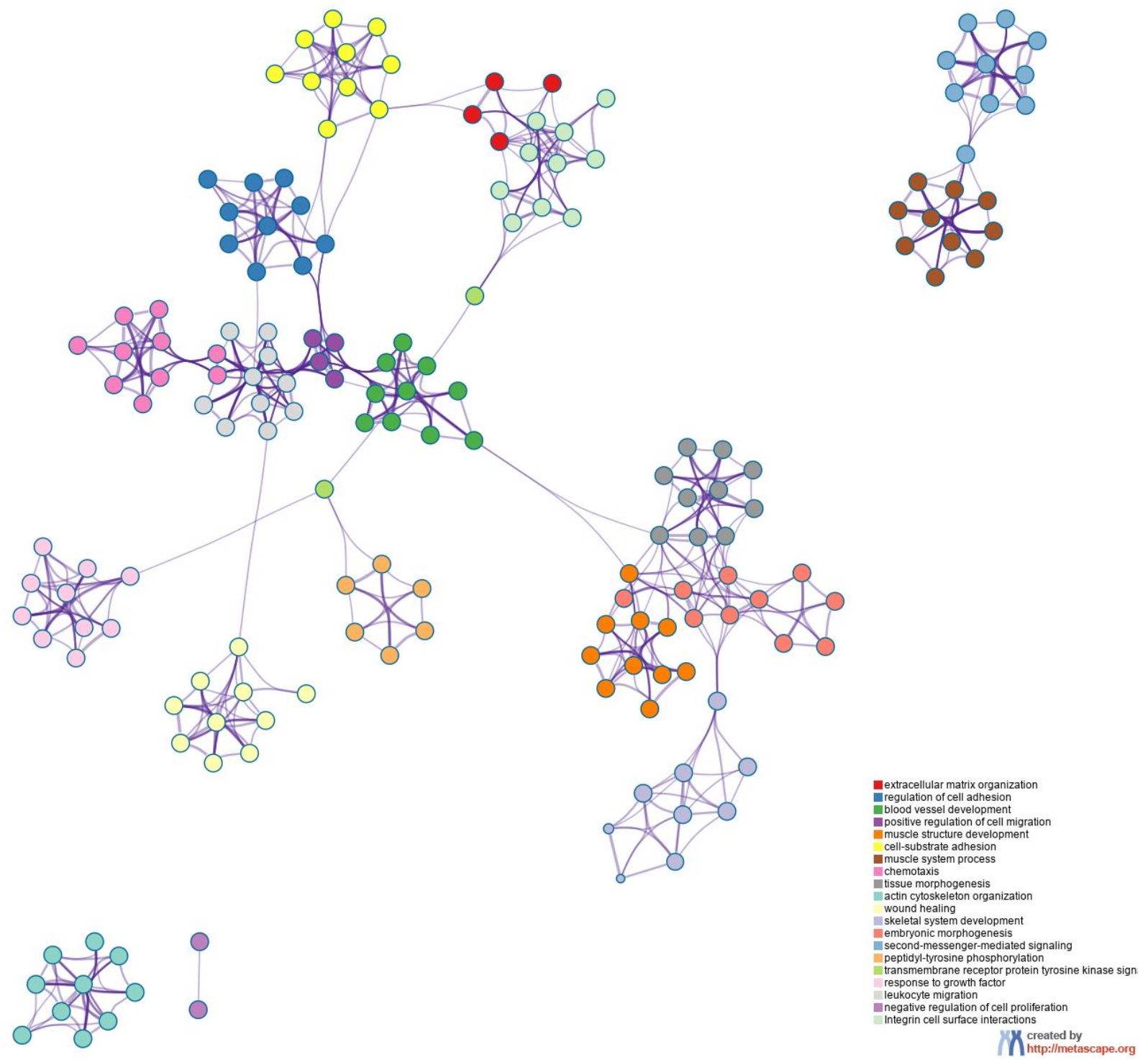

Figure 23. Subset of enriched terms in the list of differentially up-regulated genes between the groups Control Infected vs Supplemented Infected. Each term is represented by a node, its size is proportional to the number of genes belonging to this term. Terms with a similarity larger than 0.3 are connected by borders, they have the best p-values from each of the 20 clusters. There are no more than 15 terms per cluster and no more than 250 terms in total. The nodes are coloured by cluster identification, where nodes that share the same cluster identification are generally close to each other. 


\subsection{Protein Network analysis}

Only the up-regulated gene list generated by the comparison Supplemented not Infected vs Control not Infected originated a protein network. The three connected proteins are part of the Hedgehog (or Smoothened) signalling pathway (Figure 24).

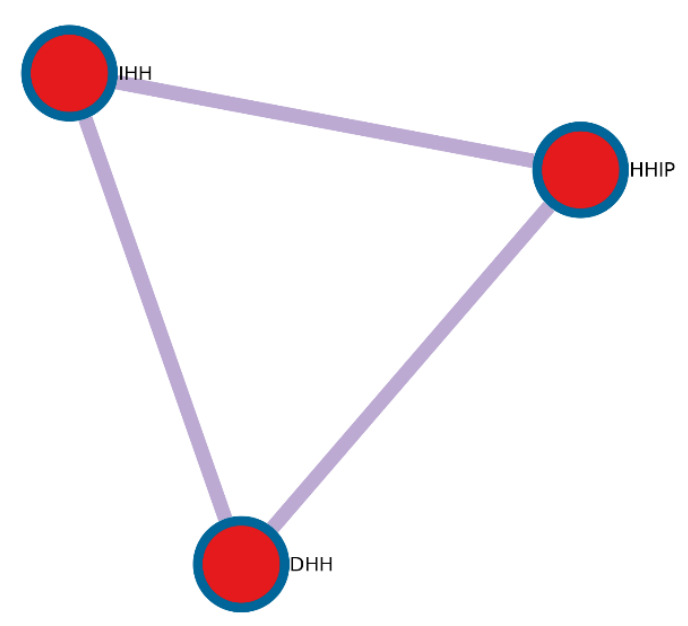

Figure 24. Protein network generated in the up-regulated gene list of the comparison Supplemented not Infected vs Control not Infected. HHIP= Hedgehog interacting protein, $\mathrm{IHH}=$ Indian Hedgehog protein, $\mathrm{DHH}=$ Desert Hedgehog protein.

\subsubsection{Gene expression validation by RT-qPCR}

In the genes assessed by RT-qPCR the differential expression followed the same pattern as in the RNA sequencing data analysis. While INHBA and HSD17B1 were up-regulated in the supplemented groups, the gene Complement 7 was down-regulated on both of them. KDM5B is down-regulated in Control not Infected and RABEP1 is up-regulated in the control infected group.

The differences in gene expression between groups Supplemented not Infected vs Control not Infected and Supplemented Infected vs Control Infected are shown in Figure 25. 

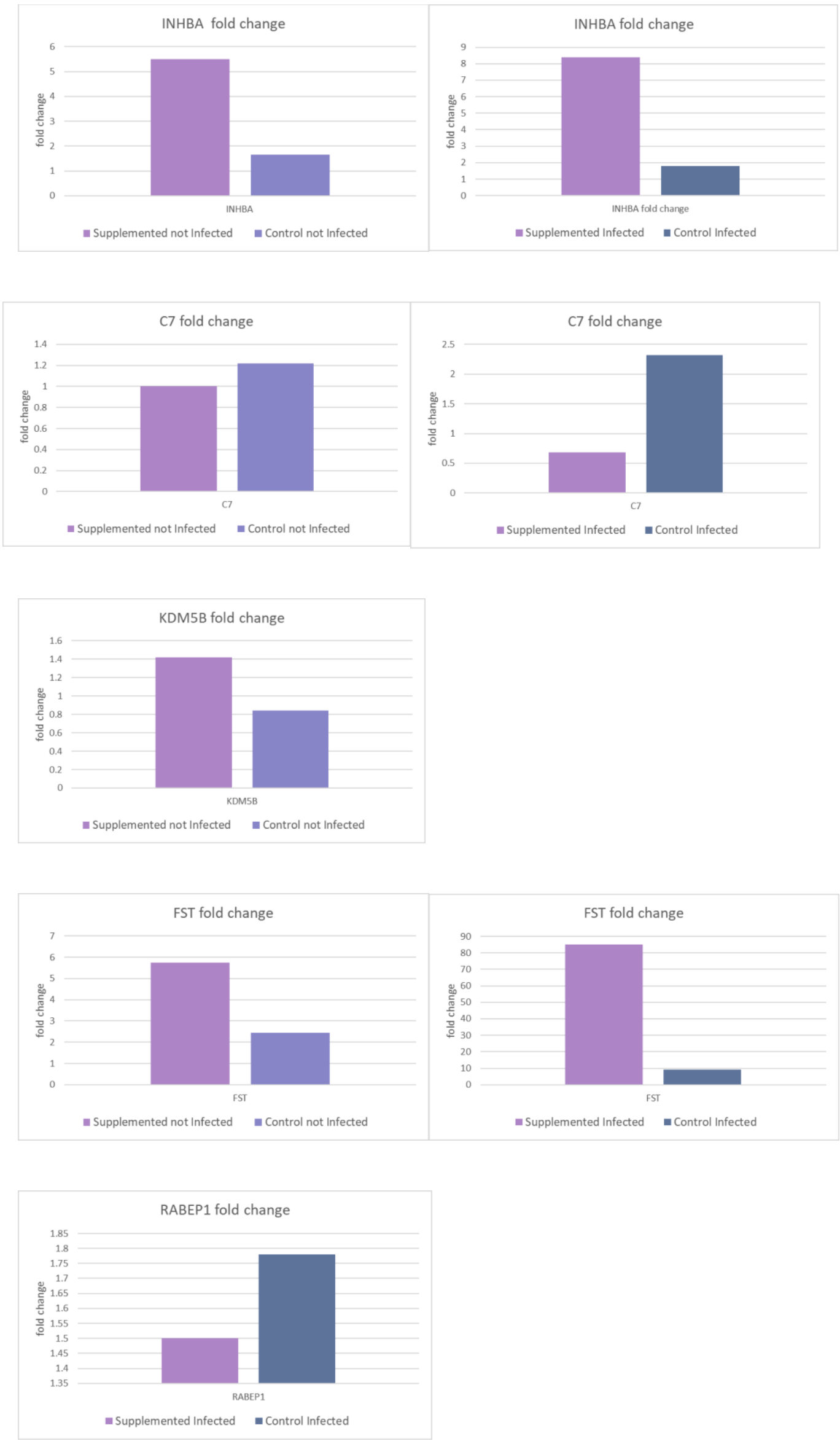


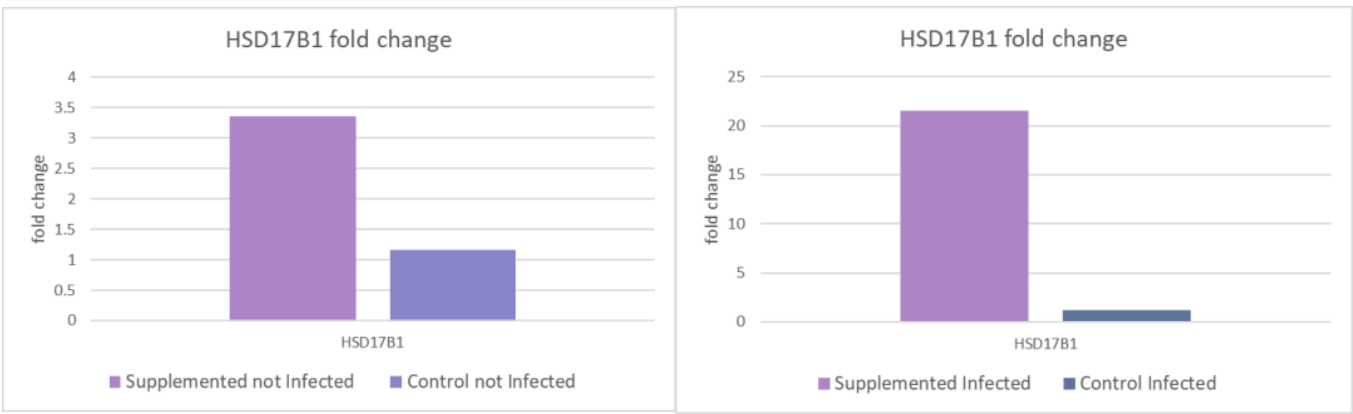

Figure 25. Differences in gene expression measured by qPCR in the comparisons Supplemented not Infected vs Control not Infected and Supplemented Infected vs Control Infected. 


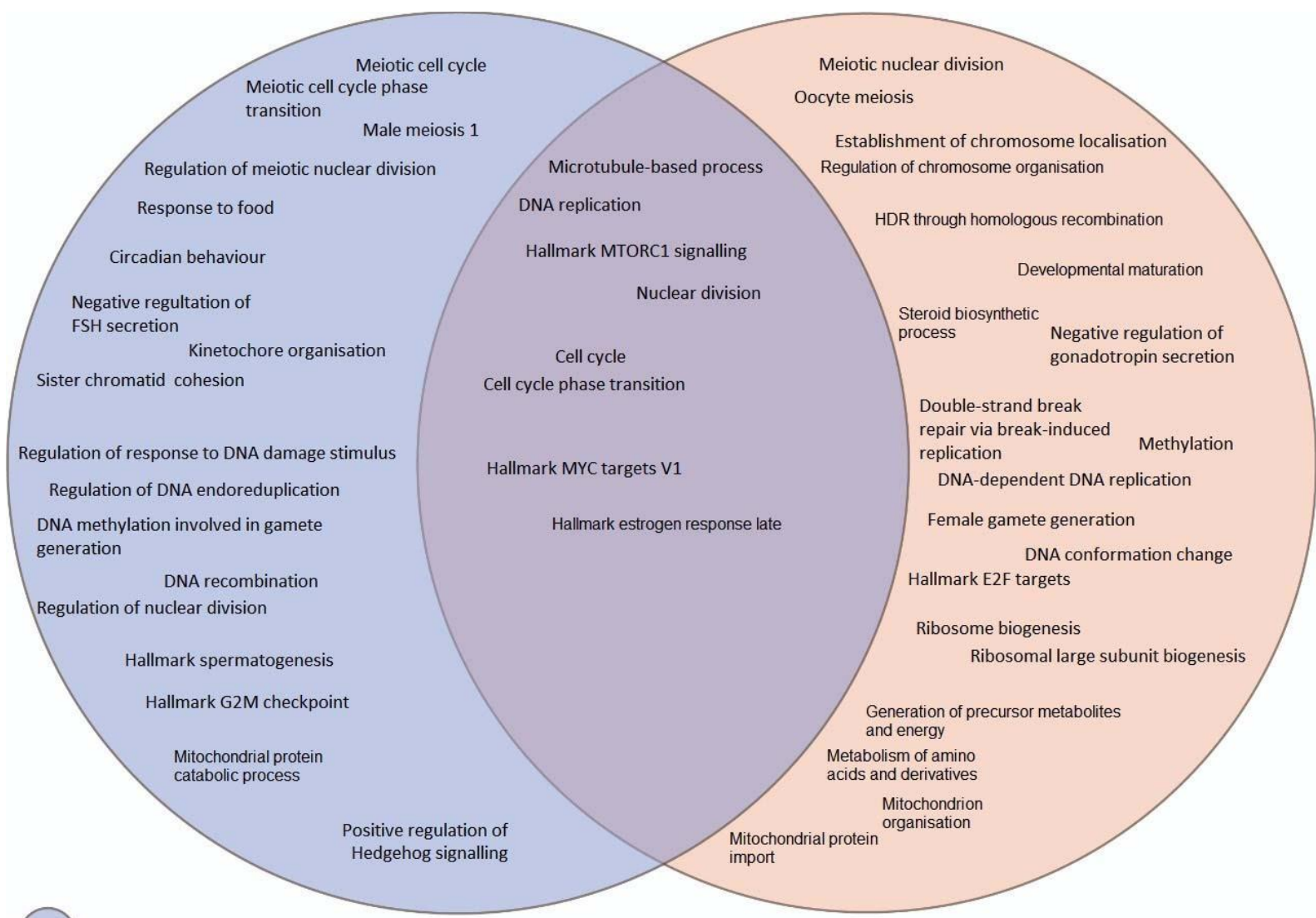

Up-regulated processes in the comparison Supplemented not infected vs. Control not infected

Up-regulated processes in the comparison Supplemented infected vs. Control infected

Up-regulated processes in common between the comparisons Supplemented not infected vs. Control not infected and Supplemented infected vs. Control infected

Figure 26. Enriched processes found in the up-regulated gene lists of the comparisons Supplemented not Infected vs Control not Infected and Supplemented Infected vs Control Infected. The processes that were found enriched in common in the two comparisons are represented in the intersection of the two circles. 


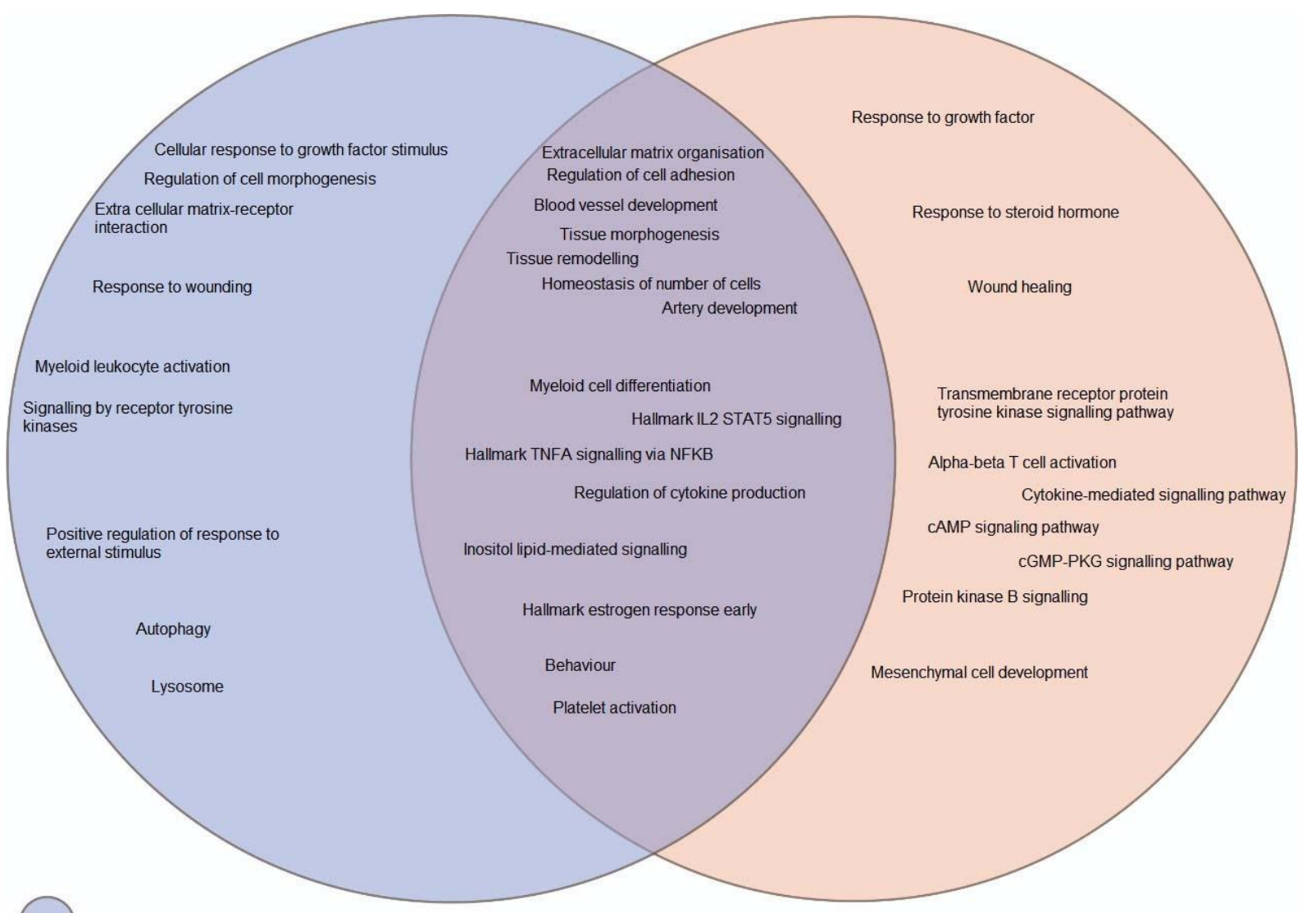

Down-regulated processes in the comparison Supplemented not infected vs. Control not infected

Down-regulated processes in the comparison Supplemented infected vs. Control infected

Down-regulated processes in common between the comparisons Supplemented not infected vs. Control not infected and Supplemented infected vs. Control infected

Figure 27. Enriched processes found in the down-regulated gene lists of the comparisons Supplemented not Infected vs Control not Infected and Supplemented Infected vs Control Infected. The processes that were found enriched in common in the two comparisons are represented in the intersection of the two circles. 


\subsection{DISCUSSION}

Although there were no differences in body weight and the number of $H$. contortus eggs in the groups of infected ewe lambs, differences were noticeable between groups at the ovarian gene expression levels. Supplemented groups presented mostly enriched processes in their up-regulated genes related to meiotic division, gamete generation, DNA replication and methylation. The not supplemented groups had in their up-regulated gene lists enriched processes related to immune response, inflammation and tissue morphogenesis.

Both supplemented groups present many enriched biological meiotic processes related to control groups, meaning that these processes were down-regulated in the control groups. Only germ cells are capable of meiotic division. Meiosis resumes at puberty when sets of oocytes are stimulated to undergo the first meiotic division with each oestrous cycle. It is not until the oocyte reaches approximately $80 \%$ of its final size that it becomes capable of resume meiosis(Albertini et al., 2003). When puberty begins, in each reproductive cycle, follicles grow to the preovulatory stage and are then stimulated by luteinizing hormone (LH) from the pituitary to restart meiosis (Jaffe and Egbert, 2017). The fact that meiosis processes are up-regulated in the supplemented groups in relation to control groups could mean that the extra protein favoured meiotic oocyte activation.

There are some different processes related to meiosis that are enriched in supplemented groups. Supplemented Infected groups present enriched Oocyte meiosis, Female gamete generation, Methylation processes and Double-strand break repair via break-induced replication processes. In Supplemented not Infected the processes of Meiotic cell cycle, DNA methylation involved in gamete generation, Meiotic cell cycle phase transition and Regulation of response to DNA damage stimulus are enriched. One explanation could be that even having reached a meiotic activation state, the groups are at slightly different moments of this meiotic activation state. Another possibility is that these differences are due to the infection's impact.

One of the pieces of evidence that supplemented infected may be in a more advanced stage of meiotic activation is the up-regulation of the genes PLK1 and CDC42. In both supplemented groups PLK1 and CDC42 are up-regulated compared to control groups, but in the Infected group, their up-regulation is higher than the supplemented not infected group. These genes are part of the progression from Metaphase I to Metaphase II. When PLK1 gene expression is decreased, it maintains the arrest in Metaphase I, and when it increases, it helps to segregate the chromosomes. When CDC42's expression is increased, cytokinesis and polar body I extrusion occur in several mammalian species(Leblanc et al., 2011; Sharma et al., 2018).

Meiosis requires highly specialised chromosomal connections. Essential for homolog chromosome segregation during Metaphase I, the gene SMC1B is up-regulated in supplemented groups, it regulates the sister chromatid separation process. Sister centromeres are forced to act in tandem at metaphase I. The up-regulation of CENPT (kinetochore assembly) and CENPS (resolution of meiotic recombination intermediates) suggest that these forces are occurring in the ovaries of both supplemented groups. Another important event of meiosis is the spindle assembly. The genes F-BOX only protein 5 (FBXO5 or EMI1) and Aurora kinase A(AURKA) which participate specifically in spindle assembly involved in female meiosis, are up-regulated in supplemented groups. FBXO5's role in meiosis of oocyte maturation is to inactivate APC-FZR1 complex, leading to metaphase arrest of the second meiotic division before fertilization (Homer, 2013). AURKA accumulates to microtubules organising centres shortly before germinal vesicle breakdown, contributing to meiosis resumption in mice's and bovine oocytes (Mahdipour et al., 2015; Saskova et al., 2008). 
The gene INHBA is only up-regulated in ewe lambs supplemented with protein in their diet despite all groups being of highly similar age and weight. INHBA expression is higher in antral follicles; it increases during puberty because the elevated levels of FSH and LH recruit more ovarian follicles to develop beyond the antral stage (Namwanje and Brown, 2016). Even though INHBA is expressed in the middle phase of the luteal phase, many genes are responsible for orchestrating this phase, so it would be imprecise to determine if these groups were in this specific oestrus cycle phase. Besides, in the gene pathways enrichment analysis - which accounts for all the differentially expressed genes to define which processes are more or less enriched- the ovulation process was not found differentially expressed. HSD17B1 gene expression was up-regulated in both groups fed supplemented protein. When one of the copies of this gene was not functional, female mice suffered from subfertility (Kemiläinen et al., 2016), suggesting an essential role for HSD17B1 in female fertility.

Both supplemented groups present in common Hallmark MTORC1 signalling process. That could be due to the extra amount of protein being provided to these animals, so their ovaries activated MTORC signalling. MTORC1 is an environmental tissue sensor, also activated by amino acids. Activated mTORC1 phosphorylates proteins involved in mRNA translation to accelerate rates of total protein synthesis in cells. So, the animal's nutritional and physiological states are integrated by mTORC1 to regulate the rate of global protein synthesis. MTOR is an essential mechanism of primordial follicle activation in oocytes, although not necessary for the transition from primordial to the primary follicle (Guo and Yu, 2019). Pharmacological inhibition of mTORC1 activity in vivo led to the suppression of primordial follicle activation. The suppressive effect of this inhibition on primordial follicle activation was reproduced in cultured ovaries (Tong et al., 2013). Moreover, in pubertal female rats, acute activation of mTOR by l-leucine stimulates Luteinising Hormone secretion and partially rescues LH suppression caused by chronic food restriction (Roa et al., 2009). In female mice, the overexpression of MTORC1 signalling caused premature primordial follicles activation (Adhikari et al., 2009). Thus, if the MTORC1 signalling pathway is activated, it could be aiding primordial follicles activation.

It is known that excessive MTORC1 activation in older individuals is linked to chronic diseases, as mTORC1 inhibition prolonged life span. On the other side, its activation is necessary for young individuals for cell growth, proliferation, differentiation and metabolism in response to hormones leading to appropriate development (Shoveller et al., 2018).

In addition, specific transcription factors for primordial follicle activation (LHX8, NOBOX, SOHLH1 and FOXL2) were up-regulated in the supplemented infected group compared to control infected. The Folliculogenesis specific basic helix-loop-helix transcription factor (FIGLA) gene is also up-regulated in the supplemented groups. FIGLA transcription factor regulating the expression of oocyte-specific genes that initiate folliculogenesis. Its increased expression was associated to primordial follicles formation (Bayne et al., 2004; Fowler et al., 2009; Lei et al., 2010). The deletion of NOBOX in ovaries led to a loss of follicles after birth and disrupted transition of primordial follicles to primary follicles (Rajkovic et al., 2004). LHX8 defficiency in ovaries also caused a problem in the transition from primordial to growing follicles and follicles survival(Choi et al., 2008). The primordial follicles of SOHLH1-deleted ovaries present limited growth and their surrounding granulosa cells did not differentiate into cuboidal cells (Lim and Choi, 2012). Female mice that lack FOXL2 had premature ovarian failure, follicles' somatic cell failed to develop around growing oocytes (Uda et al., 2004)

In up-regulated enriched processes of the supplemented not infected group, the Negative Regulation of Follicle Hormone Secretion process was observed. In the Supplemented Infected, the Negative regulation of gonadotropin secretion was represented. The Supplemented Infected animals present up-regulation of genes related 
to later follicle development as FSHR, LHCGR, PGR and STAR. These genes were not differentially expressed in the supplemented not infected group. Maybe the follicles in Supplemented Infected - at a more advanced maturation stage - provided the negative regulation of both gonadotropic hormones (FSH and LH). The ovarian follicles in Supplemented not Infected, being in a less advanced stage, down-regulated only FSH expression but not that of LH because they still needed LH to develop further. Gonadotropins are required for antral follicle development. FSH receptor(FSHR) expression has been detected in follicles with one to two layers of granulosa cells in sheep(Tisdall et al., 1995). As the follicle growth progresses, it is surrounded by more cell layers, and in the final maturation stage, it becomes more responsive to LH(Fair, 2003; Jaffe and Egbert, 2017).

The biological process Response to food was enriched only in the Supplemented not Infected group's up-regulated processes. It is a relevant process in the pubertal period because pubertal timing is metabolically controlled to prevent fertility when energy is not sufficient in the body. This correlation between pubertal age and nutrition involves peripheral hormones communicating to the hypothalamus that the animal achieved a reasonable body condition to be fertile (Fernandez-Fernandez et al., 2006; Sanchez-Garrido and Tena-Sempere, 2013). One upregulated gene that is part of this process is Nucleobinding 2(NUCB2 or Nesfatin 1). This gene modulates appetite and energy expenditure activating the sympathetic nervous system, and has a crucial role in typical puberty onset in rats. Pubertal female rats fasting for 48 hours led to decreased hypothalamic levels of NUCB2 mRNA and protein (García-Galiano et al., 2010). Our lambs presented normal beta-hydroxybutyrate levels, its levels reliably indicate negative energy balance (Raboisson et al., 2014) so we may assume that they were not in a metabolic scenario similar to fasting.

Circadian behaviour was only found up-regulated in the Supplemented not Infected group compared to the Control not Infected group. Maybe the Circadian behaviour process was enriched in supplemented not infected and not in the infected animals because parasite infections cause disruption of circadian rhythms/behaviour in the hosts. The circadian clock in immune cells modulated Leishmania infection's magnitude (Kiessling et al., 2017). Mice infected with malaria (Plasmodium chabaudi) had their circadian rhythms in behaviour and physiology disrupted (Prior et al., 2019). All cells in the ovary maintain a molecular clock implicated in the processes of follicular growth, steroid hormone synthesis, and ovulation (Sellix, 2015). There is a relationship between the expression pattern of circadian genes and steroidogenesis in the human ovary (Chen et al., 2016). Melatonin receptors are present in the ovary - in human preovulatory follicles, sheep antral follicular fluid and oocytes and cows cumulus cells (Tamura et al., 2009; Tian et al., 2017; Xiao et al., 2019). The circadian melatonin rhythm is essential for synchronising reproductive response to mammals' environmental conditions (Armstrong, 1989),especially in sheep - seasonal poliestric animals. The reproductive cycle and diseases can disrupt the timing of clock gene expression in the ovary. Disruption of the circadian rhythm negatively affects reproductive function and fertility in rodent models and women (Sciarra et al., 2020; Sellix, 2015). Considering these arguments, it is a positive finding that Circadian behaviour process was up-regulated.

The Smoothened signalling pathway (also known as Hedgehog signalling) is a process enriched only in the up-regulated gene list of Supplemented not Infected. The smoothened signalling pathway cooperates in the follicles' development because it allows the granulosa cells to induce the expression of target genes in theca cells. This communication is fundamental to the ovarian folliculogenesis and steroidogenesis (Wijgerde et al., 2005). The genes HHIP (Hedgehog interacting protein), IHH (Indian Hedgehog protein) and DHH (Desert Hedgehog protein) found enriched in the protein network analysis are part of the Hedgehog signalling pathway. When female mice double lack DHH and IHH they are infertile due to a lack of theca cells and their steroid product androgen(Liu et al., 2018), so we 
may deduce that the interaction of these genes/proteins could have a positive impact on the ovarian function of Supplemented not infected animals.

Another enriched process up-regulated in both groups is the Microtubule-based process. The unstable microtubule population is found when cell structures composed by microtubules need to be assembled and disassembled quickly. It is a process that organises cell structure and prepares it for the division. The meiotic spindle positioning, migration, anchoring, and rotation are determined by microtubule and actin filaments in mouse oocytes. Oocytes rely on microtubules' intrinsic properties and their associated motor proteins to set up the meiotic spindle(Wang et al., 2011) . As both groups have many enriched processes related to cell division, this process is a necessary previous step. Similarly, the process of DNA replication is a necessary previous step to both mitosis and meiosis, so it is not surprising that it is enriched in both supplemented groups.

We found on both up-regulated gene lists of not supplemented groups, several enriched processes related to the immune response. Among the common processes between Control not Infected and Control Infected were Leukocyte migration, Regulation of Cytokine production, Hallmark Inflammatory response, Hallmark TNFA signalling via NFKB and Hallmark IL2 STAT5 signalling. Reproduction and innate immunity are conserved and driving forces throughout evolution - they are integrated and probably divide common pathways.

On both not supplemented groups, TNFA signalling process is enriched in the up-regulated genes list. TNFA protects immature follicles from gonadotropins employing inhibitory effects on gonadotropin receptors' expression. These inhibitory effects might be necessary for the maintenance of follicles for future ovulations. Mice lacking the TNFA's receptor had increased ovarian responsiveness to gonadotropins during the prepubertal period (Roby et al., 1999). According to this finding, in theory, TNFA signalling pathway could be repressing gonadotropin action in the ovarian follicles because they were not mature enough. However, these ewe lambs had already reached between 10 - 11 months of age and were on time to activate their follicles. TNFA signalling enriched may be seen as a sign that the not supplemented groups' ovarian follicles were in a less mature stage.

Also, on both not supplemented groups up-regulated lists, there were common processes related to tissue morphogenesis like Tissue remodelling, Tissue morphogenesis, Regulation of cell adhesion, Extracellular matrix organisation, Artery development and Blood vessel development. However, there were more processes related to tissue morphogenesis in the Control Infected than in the Control not Infected, such as Collagen formation, Wound healing, Cell junction organisation, Cellular component assembly, Regulation of animal organ morphogenesis and Endothelium development. These enriched processes could be a part of the tissue morphological homeostasis - a process responsible for maintaining differentiated tissues. The tissue control system is performed by the immune system (monocytederived cells, T lymphocytes and immunoglobulins), by the autonomic innervation - which controls the number and volume of cells and some vascular endothelial cells (Bukovsky, 2011). When there is an intense remodelling of the ovary, some immune processes have to be up-regulated, such as macrophage activation (Wagner et al., 2020; Wu et al., 2004). The processes of Developmental growth, Reproductive system development and Response to growth factor stimulus were up-regulated compared to supplemented protein animals. We could deduce that, at this moment, the ovary of not supplemented animals is prioritising growing or remodelling its tissue instead of meiotic activation.

It could be argued that earlier primordial follicle activation and meiotic activation of pre-ovulatory follicles could lead to premature depletion of the ovarian reserve. However, these animals were in the expected age for pubertal timing. Furthermore, they were suffering from a debilitating infection that could have delayed oocyte maturation. Therefore, in our experiment, protein supplementation enabled the animals to proceed with meiotic activation, which did not occur in the control infected group. Our findings suggest that the infection did not delay 
follicle activation in the group that was supplemented with protein. Also, the ovaries of supplemented not infected reached a meiotic activation stage when the control not infected did not. 


\section{REFERENCES}

Adhikari, D., Zheng, W., Shen, Y., Gorre, N., Hämäläinen, T., Cooney, A.J., Huhtaniemi, I., Lan, Z.J., Liu, K., 2009. Tsc/mTORC1 signaling in oocytes governs the quiescence and activation of primordial follicles. Hum. Mol. Genet. 19, 397-410. https://doi.org/10.1093/hmg/ddp483

Albertini, D.F., Sanfins, A., Combelles, C.M.H., 2003. Origins and manifestations of oocyte maturation competencies. Reprod. Biomed. Online 6, 410-415. https://doi.org/10.1016/S1472-6483(10)62159-1

Armstrong, S.M., 1989. Melatonin and circadian control in mammals. Experientia 45, $932-938$. https://doi.org/10.1007/BF01953050

Bayne, R.A.L., da Silva, S.J.M., Anderson, R.A., 2004. Increased expression of the FIGLA transcription factor is associated with primordial follicle formation in the human fetal ovary. Mol. Hum. Reprod. 10, 373-381. https://doi.org/10.1093/molehr/gah056

Bukovsky, A., 2011. Immune Maintenance of Self in Morphostasis of Distinct Tissues, Tumour Growth and Regenerative Medicine. Scand. J. Immunol. 73, 159-189. https://doi.org/10.1111/j.1365-3083.2010.02497.x

Chen, M., Xu, Y., Miao, B., Zhao, H., Luo, L., Shi, H., Zhou, C., 2016. Expression pattern of circadian genes and steroidogenesis-related genes after testosterone stimulation in the human ovary. J. Ovarian Res. 9. https://doi.org/10.1186/s13048-016-0264-5

Choi, Y., Ballow, D.J., Xin, Y., Rajkovic, A., 2008. Lim homeobox gene, Lhx8, is essential for mouse oocyte differentiation and survival. Biol. Reprod. 79, 442-449. https://doi.org/10.1095/biolreprod.108.069393

Davis, I.F., Brien, F.D., Findlay, J.K., Cumming, I.A., 1981. Interactions between dietary protein, ovulation rate and follicle stimulating hormone level in the ewe. Anim. Reprod. Sci. 4, 19-28. https://doi.org/10.1016/03784320(81)90016-6

Dupont, J., Scaramuzzi, R.J., Reverchon, M., 2014. The effect of nutrition and metabolic status on the development of follicles, oocytes and embryos in ruminants. Animal 1031-1044. https://doi.org/10.1017/S1751731114000937

Fair, T., 2003. Follicular oocyte growth and acquisition of developmental competence. Anim. Reprod. Sci. 78, 203216. https://doi.org/10.1016/S0378-4320(03)00091-5

Fernandez-Fernandez, R., Martini, A.C., Navarro, V.M., Castellano, J.M., Dieguez, C., Aguilar, E., Pinilla, L., TenaSempere, M., 2006. Novel signals for the integration of energy balance and reproduction. Mol. Cell. Endocrinol. 254-255, 127-132. https://doi.org/10.1016/j.mce.2006.04.026

Fowler, P.A., Flannigan, S., Mathers, A., Gillanders, K., Lea, R.G., Wood, M.J., Maheshwari, A., Bhattacharya, S., Collie-Duguid, E.S.R., Baker, P.J., Monteiro, A., O’Shaughnessy, P.J., 2009. Gene expression analysis of human fetal ovarian primordial follicle formation. J. Clin. Endocrinol. Metab. 94, 1427-1435. https://doi.org/10.1210/jc.2008-2619

García-Galiano, D., Navarro, V.M., Roa, J., Ruiz-Pino, F., Sánchez-Garrido, M.A., Pineda, R., Castellano, J.M., Romero, M., Aguilar, E., Gaytán, F., Diéguez, C., Pinilla, L., Tena-Sempere, M., 2010. The anorexigenic neuropeptide, nesfatin-1, is indispensable for normal puberty onset in the female rat. J. Neurosci. 30, 7783-7792. https://doi.org/10.1523/JNEUROSCI.5828-09.2010 
Guo, Z., Yu, Q., 2019. Role of mTOR Signaling in Female Reproduction. Front. Endocrinol. (Lausanne). https://doi.org/10.3389/fendo.2019.00692

Homer, H., 2013. The APC/C in female mammalian meiosis i. Reproduction 146. https://doi.org/10.1530/REP-130163

Hunt, P.A., Hassold, T.J., 2008. Human female meiosis: what makes a good egg go bad? Trends Genet. 24, 86-93. https://doi.org/10.1016/j.tig.2007.11.010

Imperiale, F.A., Busetti, M.R., Suárez, V.H., Lanusse, C.E., 2004. Milk excretion of ivermectin and moxidectin in dairy sheep: Assessment of drug residues during cheese elaboration and ripening period. J. Agric. Food Chem. 52, 6205-6211. https://doi.org/10.1021/jf049117n

Jaffe, L.A., Egbert, J.R., 2017. Regulation of Mammalian Oocyte Meiosis by Intercellular Communication Within the Ovarian Follicle. Annu Rev Physiol. 10, 237-260. https://doi.org/10.1146/annurev-physiol-022516034102.Regulation

Kemiläinen, H., Adam, M., Mäki-Jouppila, J., Damdimopoulou, P., Damdimopoulos, A.E., Kere, J., Hovatta, O., Laajala, T.D., Aittokallio, T., Adamski, J., Ryberg, H., Ohlsson, C., Strauss, L., Poutanen, M., 2016. The hydroxysteroid $(17 \beta)$ dehydrogenase family gene HSD17B12 is involved in the prostaglandin synthesis pathway, the ovarian function, and regulation of fertility. Endocrinology 157, 3719-3730. https://doi.org/10.1210/en.2016-1252

Kiessling, S., Dubeau-Larameé, G., Ohm, H., Labrecque, N., Olivier, M., Cermakian, N., 2017. The circadian clock in immune cells controls the magnitude of Leishmania parasite infection. Sci. Rep. 7, 1-11. https://doi.org/10.1038/s41598-017-11297-8

Leblanc, J., Zhang, X., McKee, D., Wang, Z.B., Li, R., Ma, C., Sun, Q.Y., Liu, X.J., 2011. The small GTPase Cdc42 promotes membrane protrusion during polar body emission via ARP2-nucleated actin polymerization. Mol. Hum. Reprod. 17, 305-316. https://doi.org/10.1093/molehr/gar026

Lei, L., Jin, S., Mayo, K.E., Woodruff, T.K., 2010. The interactions between the stimulatory effect of follicle-stimulating hormone and the inhibitory effect of estrogen on mouse primordial folliculogenesis. Biol. Reprod. 82, 13-22. https://doi.org/10.1095/biolreprod.109.077404

Lim, E.J., Choi, Y., 2012. Transcription factors in the maintenance and survival of primordial follicles. Clin. Exp. Reprod. Med. 39, 127-131. https://doi.org/10.5653/cerm.2012.39.4.127

Liu, C., Rodriguez, K.F., Brown, P.R., Yao, H.H.C., 2018. Reproductive, physiological, and molecular outcomes in female mice deficient in Dhh and Ihh. Endocrinology 159, 2563-2575.

Mahdipour, M., Leitoguinho, A.R.C., Zacarias Silva, R.A., Van Tol, H.T.A., Stout, T.A.E., Rodrigues, G., Roelen, B.A.J., 2015. TACC3 is important for correct progression of meiosis in bovine oocytes. PLoS One 10, 1-20. https://doi.org/10.1371/journal.pone.0132591

McKellar, Q.A., Scott, E.W., 1990. The benzimidazole anthelmintic agents-a review. J. Vet. Pharmacol. Ther. https://doi.org/10.1111/j.1365-2885.1990.tb00773.x

Mcrae, K.M., Stear, M.J., Good, B., Keane, O.M., 2015. The host immune response to gastrointestinal nematode infection in sheep. Parasite Immunol. 37, 605-613. https://doi.org/10.1111/pim.12290

Raboisson, D., Mounié, M., Maigné, E., 2014. Diseases, reproductive performance, and changes in milk production associated with subclinical ketosis in dairy cows: A meta-analysis and review. J. Dairy Sci. 97, 7547-7563. https://doi.org/10.3168/jds.2014-8237 
Rajkovic, A., Pangas, S.A., Ballow, D., Suzumori, N., Matzuk, M.M., 2004. NOBOX deficiency disrupts early folliculogenesis and oocyte-specific gene expression. Science (80-. ). 305, 1157-1159. https://doi.org/10.1126/science.1099755

Roa, J., Garcia-Galiano, D., Varela, L., Sánchez-Garrido, M.A., Pineda, R., Castellano, J.M., Ruiz-Pino, F., Romero, M., Aguilar, E., López, M., Gaytan, F., Diéguez, C., Pinilla, L., Tena-Sempere, M., 2009. The mammalian target of rapamycin as novel central regulator of puberty onset via modulation of hypothalamic Kiss1 system. Endocrinology 150, 5016-5026. https://doi.org/10.1210/en.2009-0096

Roby, K.F., Son, D.S., Terranova, P.F., 1999. Alterations of events related to ovarian function in tumor necrosis factor receptor type I knockout mice. Biol. Reprod. 61, 1616-1621. https://doi.org/10.1095/biolreprod61.6.1616

Sanchez-Garrido, M.A., Tena-Sempere, M., 2013. Metabolic control of puberty: Roles of leptin and kisspeptins. Horm. Behav. 64, 187-194. https://doi.org/10.1016/j.yhbeh.2013.01.014

Saskova, A., Solc, P., Baran, V., Kubelka, M., Schultz, R.M., Motlik, J., 2008. Aurora kinase a controls meiosis I progression in mouse oocytes. Cell Cycle 7, 2368-2376. https://doi.org/10.4161/cc.6361

Sciarra, F., Franceschini, E., Campolo, F., Gianfrilli, D., Pallotti, F., Paoli, D., Isidori, A.M., Venneri, M.A., 2020. Disruption of circadian rhythms: A crucial factor in the etiology of infertility. Int. J. Mol. Sci. 21. https://doi.org/10.3390/ijms21113943

Sellix, M.T., 2015. Circadian clock function in the mammalian ovary. J. Biol. Rhythms 30, 7-19. https://doi.org/10.1177/0748730414554222

Sharma, A., Tiwari, M., Gupta, A., Pandey, A.N., Yadav, P.K., Chaube, S.K., 2018. Journey of oocyte from metaphaseI to metaphase-II stage in mammals. J. Cell. Physiol. 233, 5530-5536. https://doi.org/10.1002/jcp.26467

Shoveller, A.K., McKnight, L.M., Wood, K.M., Cant, J.P., 2018. Lessons from animal nutritionists: dietary amino acid requirement studies and considerations for healthy aging studies. Ann. N. Y. Acad. Sci. 1418, 20-30. https://doi.org/10.1111/nyas.13546

Tamura, H., Nakamura, Y., Korkmaz, A., Manchester, L.C., Tan, D.X., Sugino, N., Reiter, R.J., 2009. Melatonin and the ovary: physiological and pathophysiological implications. Fertil. Steril. 92, 328-343. https://doi.org/10.1016/j.fertnstert.2008.05.016

Tian, X., Wang, F., Zhang, L., He, C., Ji, P., Wang, J., Zhang, Z., Lv, D., Abulizi, W., Wang, X., Lian, Z., Liu, G., 2017. Beneficial effects of melatonin on the in vitro maturation of sheep oocytes and its relation to melatonin receptors. Int. J. Mol. Sci. 18. https://doi.org/10.3390/ijms18040834

Tisdall, D.J., Watanabe, K., Hudson, N.L., Smith, P., McNatty, K.P., 1995. FSH receptor gene expression during ovarian follicle development in sheep. J. Mol. Endocrinol. 15, 273-281. https://doi.org/10.1677/jme.0.0150273

Tong, Y., Li, F., Lu, Y., Cao, Y., Gao, J., Liu, J., 2013. Rapamycin-sensitive mTORC1 signaling is involved in physiological primordial follicle activation in mouse ovary. Mol. Reprod. Dev. 80, 1018-1034. https://doi.org/10.1002/mrd.22267

Toro, C.A., Aylwin, C.F., Lomniczi, A., 2018. Hypothalamic epigenetics driving female puberty. J. Neuroendocrinol. 30,1-12. https://doi.org/10.1111/jne.12589

Tsiboukis D, Sazakli E, Jelastopulu E, L.M., 2013. Anthelmintics residues in raw milk. Assessing intake by a children population. Pol J Vet Sci. 85-91. https://doi.org/10.2478/pjvs-2013-0012.

Uda, M., Ottolenghi, C., Crisponi, L., Garcia, J.E., Deiana, M., Kimber, W., Forabosco, A., Cao, A., Schlessinger, D., Pilia, G., 2004. Foxl2 disruption causes mouse ovarian failure by pervasive blockage of follicle development. Hum. Mol. Genet. 13, 1171-1181. https://doi.org/10.1093/hmg/ddh124 
Wagner, M., Yoshihara, M., Douagi, I., Damdimopoulos, A., Panula, S., Petropoulos, S., Lu, H., Pettersson, K., Palm, K., Katayama, S., Hovatta, O., Kere, J., Lanner, F., Damdimopoulou, P., 2020. Single-cell analysis of human ovarian cortex identifies distinct cell populations but no oogonial stem cells. Nat. Commun. 11. https://doi.org/10.1038/s41467-020-14936-3

Wang, Q., Racowsky, C., Deng, M., 2011. Mechanism of the chromosome-induced polar body extrusion in mouse eggs. Cell Div. 6, 1-9. https://doi.org/10.1186/1747-1028-6-17

Wijgerde, M., Ooms, M., Hoogerbrugge, J.W., Grootegoed, J.A., 2005. Hedgehog Signaling in Mouse Ovary: Indian Hedgehog and Desert Hedgehog from Granulosa Cells Induce Target Gene Expression in Developing Theca Cells. https://doi.org/10.1210/en.2005-0311

Wu, R., Van der Hoek, K.H., Ryan, N.K., Norman, R.J., Robker, R.L., 2004. Macrophage contributions to ovarian function. Hum. Reprod. Update 10, 119-133. https://doi.org/10.1093/humupd/dmh011

Xiao, L., Hu, J., Song, L., Zhang, Y., Dong, W., Jiang, Y., Zhang, Q., Yuan, L., Zhao, X., 2019. Profile of melatonin and its receptors and synthesizing enzymes in cumulus-oocyte complexes of the developing sheep antral follicle - A potential estradiol-mediated mechanism. Reprod. Biol. Endocrinol. 17, 1-9. https://doi.org/10.1186/s12958-018-0446-7 